\title{
LEVANTAMENTO FLORÍSTICO DAS DIOSCOREACEAE (R. BR.) LINDLEY DA GADEIA DO ESPINHAÇO, MINAS GERAIS E BAHIA, BRASIL. ${ }^{1}$
}

\author{
GILBERTO G. PEDRALLI
}

Fundação Centro Tecnológico de Minas Gerais, Caixa Postal 706, 31170-000, Belo Horizonte, MG, Brasil (pedralli@cetec.br) e

Universidade Federal de Ouro Preto, Campus do Morro do Cruzeiro, 35400-000, Ouro Preto, MG, Brasil (pedralli@iceb.ufop.br)

\begin{abstract}
Floristic inventory of the Dioscoreaceae (R.Br.) Lindley of the Espinhaço Range, Minas Gerais and Bahia, Brazil). In the Espinhaço range, 27 species of Dioscorea L. occur: D. altissima Lam., D. amaranthoides Presl, D. anomala (Kunth) Griseb., D. bulbifera L., D. campestris Griseb., D. cinnamomifolia Hook., D. demourae R. Knuth, D. dodecaneura Vell., D. filiformis Griseb., D. hassleriana Chod., D. heptaneura Vell., D. laxiflora Griseb., D. maianthemoides R. Knuth, D. microbotrya Griseb., D. monadelpha (Kunth) Griseb., D. orthogoneura Hochr., D. ovata Vell., D. piperifolia Humb. \& Bonpl., D. polygonoides Humb. \& Bonpl., D. rumicoides Griseb., D. scabra Humb. \& Bonpl., D. sincorensis R. Knuth, D. sinuata Vell., D. spicata (Vell.) Pedralli, D. stenophylla Uline, D. subhastata Vell. and D. trifida L.f. Description, illustrations, and comments on habitats and geographical distribution are presented for each species.

Resumo - (Levantamento florístico das Dioscoreaceae (R.Br.) Lindley da Cadeia do Espinhaço, Minas Gerais e Bahia, Brasil). Na cadeia do Espinhaço ocorrem 27 espécies de Dioscorea L.: D. altissima Lam., D. amaranthoides Presl, D. anomala (Kunth) Griseb., D. bulbifera L., D. campestris Griseb., D. cinnamomifolia Hook., D. demourae R. Knuth, D. dodecaneura Vell., D. filiformis Griseb., D. hassleriana Chod., D. heptaneura Vell., D. laxiflora Griseb., D. maianthemoides R. Knuth, D. microbotrya Griseb., D. monadelpha (Kunth) Griseb., D. orthogoneura Hochr., D. ovata Vell., D. piperifolia Humb. \& Bonpl., D. polygonoides Humb. \& Bonpl., D. rumicoides Griseb., D. scabra Humb. \& Bonpl., D. sincorensis R. Knuth, D. sinuata Vell., D. spicata (Vell.) Pedralli, D. stenophylla Uline, D. subhastata Vell. e D. trifida L.f. São apresentadas para cada espécie descrição, ilustrações c comentários sobre hábitats e distribuição geográfica.
\end{abstract}

Key words: Taxonomy, Dioscoreaceae, Dioscorea, yams, Espinhaço Range, Brazil.

\section{Introdução}

Dioscoreaceae (R.Br.) Lindley é constituída por 6 a 9 gêneros (Knuth 1924, Barroso et al. 1974, Coursey 1980, Cronquist 1988, Brummitt 1992) e cerca de 130 a 850 espécies (Waitt 1963, Al-Shehbaz \& Schubert 1989), que se distribuem pelas regiões tropicais, subtropicais e temperadas de todo o mundo. O valor mais aceito é de 650 espécies descritas para a família (Bailey 1951, Burkill 1951, Waitt 1963, Humphries 1978, Coursey 1979, Purseglove 1979, Huber 1998, Xifreda 2000); na América do Sul ocorrem cerca de $25 \%$ destas e mais de $50 \%$ das espécies de Dioscorea L. (Smith 1937, Ayensu 1972, Lawrence 1975).

O objetivo do presente trabalho é identificar, descrever, ilustrar e analisar a distribuição geográfica das espécies de Dioscorea ocorrentes nas serras da Cadeia do Espinhaço, Minas Gerais e Bahia, Brasil (Fig. 1).

\footnotetext{
' Parte da Tese de doutorado realizada sob orientação da Dr.' Ana Maria Giulietti no Instituto de Biociências da USP.
}

\section{Material e métodos}

Foi realizado extenso levantamento bibliográfico e cartográfico, trabalhos de campo para coleta de material, e estudados os materiais dos seguintes herbários (siglas segundo Holmgren et al. 1990): ALCB, $\mathrm{AAU}, \mathrm{B}, \mathrm{BHCB}, \mathrm{BH}, \mathrm{BHMH}, \mathrm{BM}, \mathrm{CEN}, \mathrm{CEPEC}, \mathrm{CESJ}$, CTES, COL, ESAL, F, G, GUA, GUAY, HAS, HB, HBR, HRB, HRCB, HUEFS, HUH, HXBH, IAN, INPA, IBGE, ICN, K, LINN, M, MBM, MO, NY, OUPR, OXF, P, PACA, PEL, PR, QCA, R, RB, S, SEL, SMDB, SP, SPF, UB, UC, UEC, UESC, UFG, UFMT, UPCB, VIC e W.

A identificação específica foi realizada com auxílio da bibliografia especializada, além da comparação com os materiais-tipo e outras coleções depositadas nos herbários estrangeiros e nacionais, acima relacionados.

Os padrões de distribuição geográfica das espécies foram elaborados a partir dos materiais de herbário e das observações das espécies na natureza, segundo Thorne (1972) e Giulietti \& Pirani (1988). 


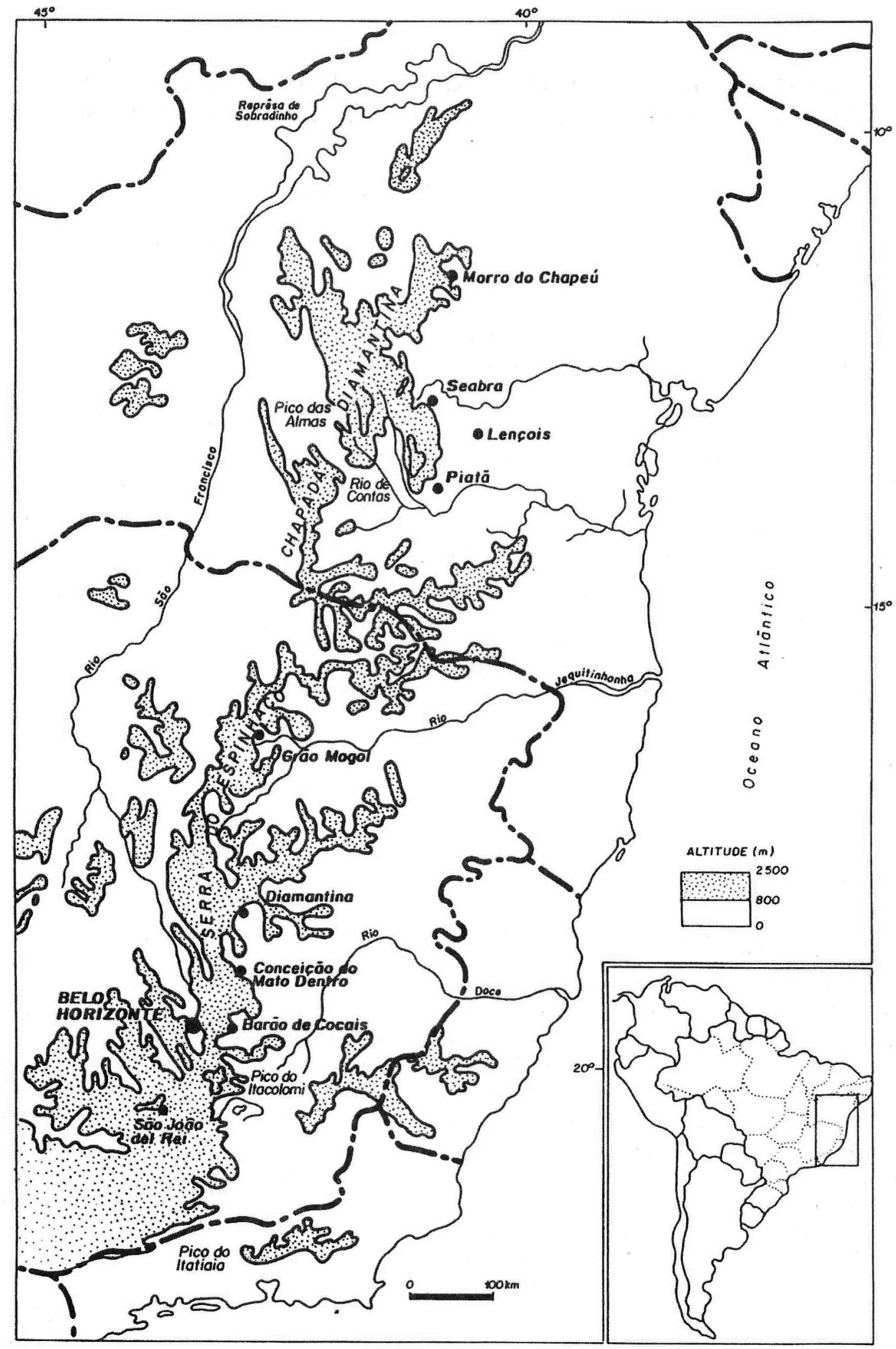

Figura 1: Localização da Cadeia do Espinhaço em Minas Gerais e Bahia. 


\section{Resultado e Discussão}

As Dioscoreaceae são plantas volúveis, apoiantes, subarbustivas ou eretas, herbáceas ou volúveis, heliófilas. Possuem folhas alternas, opostas ou espiraladas, limbo largo e freqüentemente cordado, inteiro, palmatilobado ou composto-digitado. Suas flores são unissexuadas (em plantas dióicas; flores bissexuadas apenas em Stenomeris), epíginas, pediceladas ou sésseis, com ou sem bractéolas, dispostas em panículas, racemos ou espigas. Têm perianto regular, trímero, em um ou dois ciclos, com tépalas em geral semelhantes. Os estames estão arranjados em dois verticilos de três ou o mais interno estéril, sendo os filetes distintos ou anexados às tépalas, ou, ainda, conatos em coluna estaminal; as anteras são tetraesporangiadas, introrsas ou extrorsas. O ovário é sincárpico, trilocular; o estilete trífido ou trilobado; os óvulos anátropos dispostos em placentas axiais. Os frutos triloculares têm duas sementes em cada lóculo (sementes numerosas em Stenomeris), mais raro com um lóculo estéril e o fértil com semente única, sendo do tipo cápsula, ou baga (somente em Tamus) ou sâmara (Rajania). As sementes esféricas ou comprimidas, e neste caso aladas, possuem abundante endosperma amiláceo, ou hemicelulose em Tamus. O embrião é pequeno com plúmula terminal e cotilédone lateral largo.

Foram identificadas 27 espécies de Dioscorea L. na Cadeia do Espinhaço. O sistema subterrâneo dessas espécies é do tipo rizóforo (v. Rocha \& Menezes 1997). As espécies dessa região crescem nos vários ambientes que compõem o mosaico dos campos rupestres, orla e interior de florestas de galeria e estacionais, cerrados e af loramentos rochosos em solos pedregosos e/ou arenosos, sendo a maioria das espécies anuais.

Apresentam-se a seguir, chave analítica para a identificação dessas espécies e a descrição de cada uma delas, em ordem alfabética.

\section{Chave para as espécies de Dioscorea L. da Cadeia do Espinhaço}

1. Ramos aéreos com acúleos ou espinhos; rizóforo superficial, tuberosidades carnosas ou lenhosas quando mais velhas, medula da tuberosidade principal branco-amarelada.

2. Caules aéreos com acúleos; partes espessadas carnosas 1. D. altissima

2'. Caules aéreos com espinhos; partes espessadas lenhosas 21. D. scabra

1'. Caules aéreos inermes; rizóforo superficial a profundo, medula da tuberosidade principal branca, amarelada, branco-amarelada, amarelo-alaranjada, marrom-clara, marrom-escura, avermelhada a purpúrea.
3. Caules aéreos com expansões laterais ('alados'); folhas palmatilobadas ou compostas trifolioladas.

4. Flores estaminadas com 3 estames e 3 estaminódios; tuberosidades discóides, aplanadas 23. D. sinuata

4'. Flores estaminadas com 6 estames; partes espessadas dos rizóforos ovais, cilíndricas, arredondadas ou irregulares 27. D. trifida

3'. Caules aéreos sem expansões laterais; folhas simples ou compostas trifolioladas

5. Folhas compostas trifolioladas nos ramos apicais; foliolos elípticos a linear-lanceolados ....... 24. D. spicata

5'. Folhas simples mesmo nos ramos apicais.

6. Folhas com 3,0-11,0cm compr., linear-lanceoladas ou lineares.

7. Plantas herbáceas, eretas. 3. D. anomala 7'. Plantas volúveis ou apoiantes.

8. Plantas volúveis ou apoiantes; flores estaminadas com 6 estames unidos na base quando jovens ou formando coluna; pistilódio cônico-piriforme 25.D. stenophylla

8'. Plantas apoiantes; flores estaminadas com 6 estames, unidos na base; pistilódio cônico

13. D. maianthemoides

6'. Folhas com 2,5-20,0 cm compr., cordadas, ovadas, obovadas, oblongo-lanceoladas, hastadas, deltóides, rombóides, sagitadas, elípticas, elíptico-lanceoladas, reniformes, orbiculares, ovado-lanceoladas ou cordiformes.

9. Folhas purpúreas na face abaxial, variegadas na adaxial.

10. Flores pistiladas glabras a pilosas; flores estaminadas com 3 estames, inseridos na metade da altura das tépalas, inclusos

2. D. amaranthoides

10'. Flores pistiladas pilosas; flores estaminadas com 6 estames, inseridos na base do tubo das tépalas, inclusos 8. D. dodecaneura

9'. Folhas esverdeadas a oliváceas em ambas as faces ou avermelhadas, castanhoescuras, amareladas, alaranjadas ou marrom-escuras.

11. Lianas dextrogiras.

12. Estames 6, estaminódios ausentes. 13. Estames sésseis ou com filetes até $0,1 \mathrm{~mm}$ compr. 14.D. microbotrya 
13'. Estames com filetes compridos (0,2-2,0 mm compr.). 14. Filetes unidos na base.

15. Flores estaminadas sem pistilódio 5. D. campestris

15'. Flores estaminadas com pistilódio.

16. Flores estaminadas 3-8 em cada nó floral; pistilódio cônico, cápsulas elípticas.

17. Sementes circulares, asa apical; tuberosidades discóides ou irregulares .................................17. D. ovata

17'. Sementes elípticas, asa circular, ampla, tuberosidades irregulares, piramidais ou globosas

22. D. sincorensis

$16^{\prime}$. Flores estaminadas 1-3 em cada nó floral; pistilódio cilíndrico, retuso no ápice; cápsulas obovadas ..... 4.D. bulbifera

14'. Filetes livres na base.

18. Pistilódio cilíndrico, trífido a partir de $1 / 3$ da sua altura 10. D. hassleriana

18'. Pistilódio globoso, trissulcado no ápice

12. D. laxiflora

12'. Estames 3; estaminódios presentes ou ausentes.

19. Plantas dióicas; filetes livres.

20. Estames com anteras divergentes, alternados com 3 estaminódios bilobados nas flores pistiladas 19.D. polygonoides

20 '. Estames com anteras paralelas; estaminódios 6 nas flores pistiladas

16. D. orthogoneura

19'. Plantas monóicas; filetes unidos, em coluna cilíndrica, carnosa.

21. Ápice da coluna estaminal triangular, plano; presença de amido na medula dos rizóforos 7.D. demourae

21'. Ápice da coluna estaminal circular, convexa; ausência de amido na medula dos rizóforos. 22. Ápice da coluna estaminal expandido, grosso acima das anteras; rizóforo sem substâncias lipídicas na epiderme 15. D. monadelpha

22'. Ápice da coluna cônico, sem expansão apical; rizóforos com substâncias lipídicas na epiderme 26. D. subhastata

11'. Lianas sinistrogiras.

23. Flores estaminadas com 6 estames.

24. Estames sésseis ou subsésseis até $0,1 \mathrm{~mm}$ compr.; pistilódio presente

25. Flores pistiladas com estilete inteiro, colunar; estaminódios presentes; flores estaminadas em espigas; tuberosidades dos rizóforos alongadas a irregulares 24. D. spicata
25'. Flores pistiladas com estilete dividido em 3 ramos a partir da base; estaminódios ausentes; flores estaminadas em racemos; tuberosidades dos rizóforos discóides 18. D. piperifolia

24 '. Estames com filetes presentes $(0,2-1,5 \mathrm{~mm}$ compr.); pistilódio ausente

6. D. cinnamomifolia

23'. Flores estaminadas com 3 estames.

26. Estames alternados com 3 estaminódios; anteras latero-introrsas, conectivo alargado; tuberosidades dos rizóforos circulares ou irregulares 20. D. rumicoides

26'. Estaminódios ausentes, anteras introrsas ou latero-introrsas, conectivo estreito; tuberosidades discóides ou ausentes.

27. Anteras introrsas; pistilódio cônico; sementes corn asa circular

9. D. filiformis

27'. Anteras latero-introrsas; pistilódio cilíndrico; sementes com asa apical

11. D. heptaneura

1. Dioscorea altissima Lam., Encycl. Méth. 3: 231. 1789. Tipo: "Martinique”, Plumier s.n. (Holótipo P!).

Fig. 2

Plantas dióicas. Sistema subterrâneo constituído por um rizóforo com 0,5 a $1 \mathrm{~m}$ compr. sendo a tuberosidade principal próxima da superfície do solo, ovóide, oval-lanceolada ou com formato irregular, carnosa a lenhosa quando mais velha; periderme marrom ou acinzentada e medula amarelada tornando-se alaranjadoavermelhada. A cada ano se formam a partir da principal tuberosidades arredondadas a ovais, $\operatorname{com} 1$ a $10 \mathrm{~cm}$ diâm.; periderme marrom-acinzentada e medula amarelada. Plantas perenes, lianas, ramos esverdeados, avermelhados ou castanho-escuros, dextrogiros, eretos ou apoiantes sobre árvores e arbustos, 0,5-3m compr., glabros, $1-1,5 \mathrm{~cm}$ diâm. Caules jovens em seção transversal quase circulares, quando mais velhos triangulares a tetrangulares cobertos por acúleos triangulares dispostos em fileiras sobre os ângulos caulinares; porção inferior do caule com nós e entrenós evidentes. Folhas opostas, lanceoladas ou reniformes, cartáceas, glabras, esverdeadas, 7-11 nervuras salientes na face abaxial, 3$20 \mathrm{~cm}$ compr.; pecíolos robustos, canaliculados, $2,5-5 \mathrm{~cm}$ compr. Inflorescências estaminadas racemosas, $4-18 \mathrm{~cm}$ compr., flores 1-3 por nó; bráctea oblongo-acuminada a triangular, 1-3,5mm compr., com pontuações avermelhadas; profilo com a mesma forma da bráctea, 0,8-3,2 mm compr; perianto campanulado, esverdeado a castanho-escuro, com pontuações avermelhadas distribuí- 


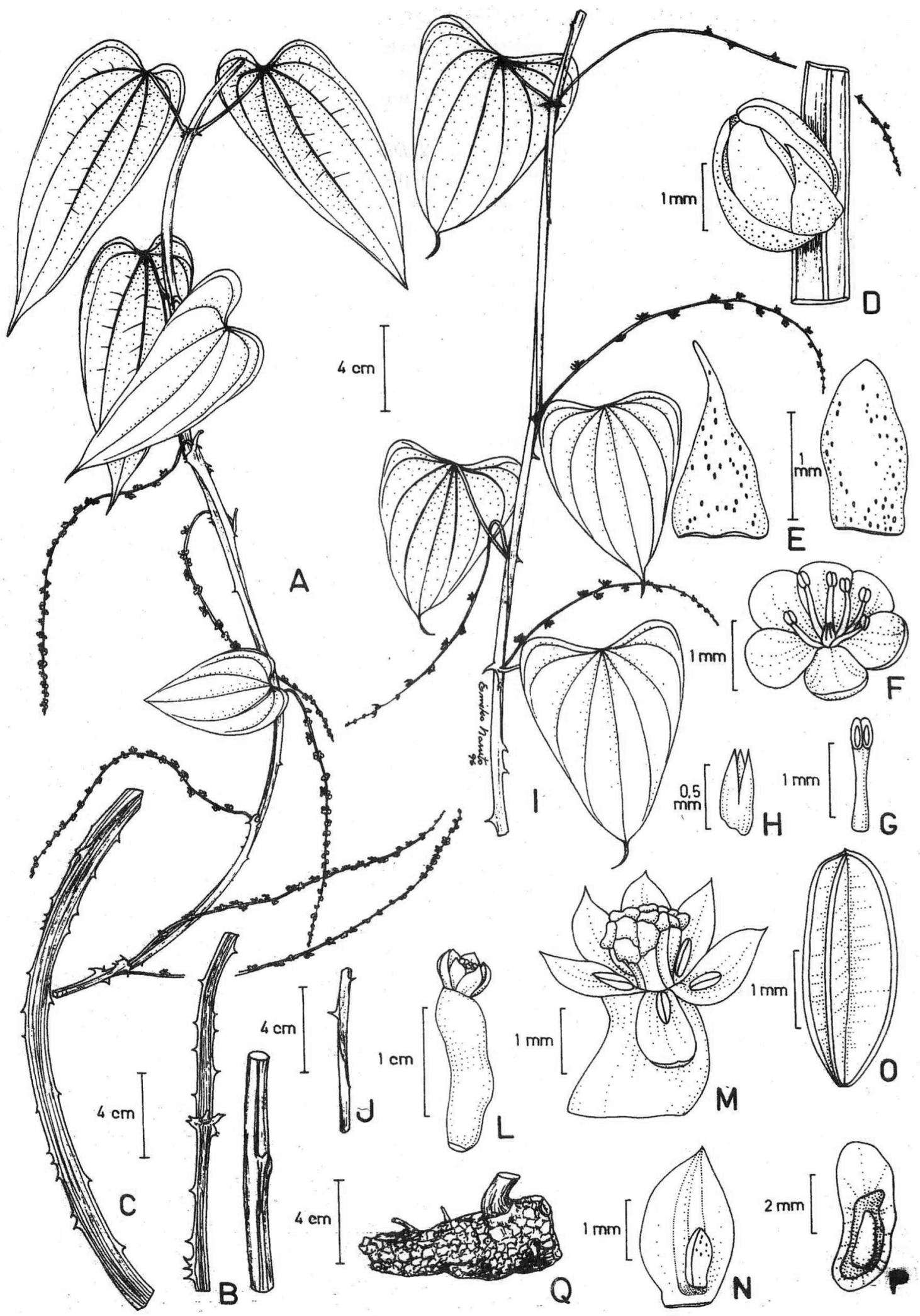

Fig. 2: Dioscorea altissima Lam. A. ramo florífero (planta masculina); B. detalhe dos ramos floríferos com espinhos e inermes; C. porção basal de um ramo com acúleos nos ângulos; D-H. flor estaminada; D. flor jovem; E. bráctea (triangular) e profilo; F. flor em antese; G. estame; H. pistilódio; I. ramo florífero (planta feminina); J. detalhe do ramo com espinhos; L-N. flor pistilada; L. flor em antese; M. perigônio, estaminódios estilete e estigma; N. tépala e estaminódio; O. cápsula; P. semente; Q. seção do sistema subterrâneo (rizóforo com tuberosidade lenhosa). (A-H: Pedralli Eं Teixeira 3343; I-N: Pedralli Ẽ Teixeira 3450; O-Q: Pedralli Ẽ Teixeira s.n.) 
das irregularmente na superfície; tépalas externas e internas oblongas, $2-3 \mathrm{~mm}$ compr.; estames 6 , inseridos na base de cada tépala; anteras ca. $0,5 \mathrm{~mm}$ compr., filetes ca. $1 \mathrm{~mm}$ compr., achatados na base, cilíndricos a partir da metade da sua altura; pistilódio crasso, cônico, ca. 0,5mm compr., estilódios 3, linear-lanceolados, ca. $0,3 \mathrm{~mm}$ compr. Inflorescências pistiladas em espigas, pêndulas, $3-10 \mathrm{~cm}$ compr.; flores isoladas em cada nó floral, sésseis, bráctea e profilo oblongo-acuminados, 1,2-3mm compr.; perianto campanulado, esverdeado a alaranjado; tépalas externas 3, oblongas, 1-3,3 mm compr.; tépalas internas 3, oblongas, 1,2-3,5mm compr.; gineceu tricarpelar, crasso, colunar; estiletes soldado na base, tripartidos no ápice, ramos bífidos, globosos na extremidade; estaminódios 6, amarelados, sésseis, ovais a oblongos, 0,2-1mm compr. Cápsulas 3-5 cm compr., oblongas, valvas esverdeadas a castanhoescuras, glabras, quando secas pardo-acinzentadas a amareladas, apiculadas, margens dilatadas. Sementes ca. $1 \mathrm{~cm}$ compr., oval-lanceoladas, marrom-escuras, ala basal alongada.

Material examinado: Bahia: Morro do Chapéu, 12.V.1957, Lordêlo 57309, fl. masc. (ALCB); Aracatu, $20 \mathrm{~km}$ ao norte de Anagé, 17.VIII.1988, Eggli 1186 (CEPEC, ZSS). Minas Gerais: Diamantina, estrada para Inhaí, 25.VII.1986, G. Pedralli E Silva 2661, fl. masc. (CEN); Belo Horizonte, campus da UFMG, Estação Ecológica, 10.X.1990, E. Tameirão Neto 221, fl. masc. (BHCB, HXBH); Moeda, rio Paraopeba, 20.IX.1993, G. Pedralli Ẽ Teixeira s.n., fr. (HXBH); Várzea da Palma, Serra do Cabral, 23.XI.1993, G. Pedralli Ẽ Teixeira 3423(HXBH); Ouro Preto, Santo Hipólito, 24.XI.1993, G. Pedralli E Teixeira 3440 (HXBH): Joaquim Felício, a $30 \mathrm{~km}$ da sede, 24.XI.1993, G. Pedralli E Teixeira 3434 (HXBH): Diamantina, Gruta do Salitre, 25.XI.1993, G. Pedralli Eo Teixeira 3443, fl. masc. (HXBH): Itambé do Mato de Dentro, estrada para Morro do Pilar, a 2km da sede, 26.XI.1993, G. Pedralli $\mathcal{E}^{\circ}$ Teixeira 3450, fl. fem. (HXBH); Belo Horizonte, campus da UFMG, Estação Ecológica, 1.XI.1994, J. Lombardi $656 \mathcal{E}^{2} \mathrm{~L}$. Temponi, fl. fem., fr. (BHCB, HXBH); Belo Horizonte, campus da UFMG, Estação Ecológica, 27.XI.1994, J. Lombardi $630 \mathcal{E}^{\circ}$ L. Temponi, fl. fem. (BHCB, HXBH).

Distribuição geográfica e hábitats: com distribuição nas Américas Central e do Sul (neotropical), a espécie na Cadeia do Espinhaço ocorre em florestas de galeria em terrenos aluvionais férteis, nos cerrados em solos argilosos, nas florestas estacionais (mesófilas) em solos arenosos e nos campos rupestres em solos pedregosos ou arenosos.

A espécie distribui-se desde as Antilhas (St. Martin, St. Vicent, St. Barts, Martinica e Guadalupe), Cuba, Porto Rico, Trinidad, Tobago, Granada, sul da América Central (Panamá), norte da América do Sul (Vene- zuela, Guiana e Suriname), Colômbia e Bolívia até o Peru. No Brasil, ocorre no Amazonas, Mato Grosso do Sul, Bahia, Minas Gerais e do Rio de Janeiro até Santa Catarina.

2. Dioscorea amaranthoides Presl, Rel. Haenk. 1: 134. 1825. Tipo: Rel. Haenk. 1, p. 136. 1825. Uma figura do hábito e das flores estaminadas (Lectótipo).

Fig. 3

Plantas dióicas. Sistema subterrâneo constituído por um rizóforo profundo com cerca de $30,0 \mathrm{~cm}$ de comprimento, tuberosidade principal irregular, da qual brotam, a cada ano, tuberosidades menores (ca. $2 \mathrm{~mm}$ diâm.); ambos os tipos apresentam medula amarelada e periderme marrom. Lianas com ramos perenes, amarelados a castanho-avermelhados, dextrogiros, 1-3m compr., glabros, $2 \mathrm{~mm}$ diâm. Caules jovens em seção transversal triangulares, estriados, inermes, quando mais velhos circulares, glabros, com pontuações escuras. Folhas alternas, obovadas a oblongo-lanceoladas, cordadas a sagitadas, com lobos basais arredondados, glabras, esverdeadas, avermelhadas ou castanho-escuras, purpúreas na face adaxial e mais raro na face abaxial, com pontuações escuras no limbo, 5 nervuras salientes em ambas as faces, $5-10 \mathrm{~cm}$ compr.; pecíolos canaliculados, $1-2,5 \mathrm{~cm}$ compr., glabros, castanho-escuros. Inflorescências estaminadas racemosas, pêndulas, $6-31 \mathrm{~cm}$ compr., flores isoladas, bráctea linear-acuminada, 0,9$1,2 \mathrm{~mm}$ compr., amarelada a castanho-escura; profilo linear, ca. $1 \mathrm{~mm}$ compr., alvo-amarelada a castanho-escuro. Flores com perianto campanulado a urceolado, amarelado a castanho-escuro, com pontuações escuras no terço superior, tépalas externas e internas oblongolanceoladas, 1,8-2,0 mm compr., com pontuações avermelhadas distribuídas irregularmente; estames 3, epitépalos, inseridos na metade da sua altura, inclusos no tubo, anteras ca. $0,3 \mathrm{~mm}$ compr., introrsas, oval-quadrangulares, globosas, deiscência longitudinal, filetes 0,2 0,6mm compr., cilíndricos, curvos no terço superior; pistilódio cônico, pequeno, tripartido, ca. $0,2 \mathrm{~mm}$ compr. Inflorescências pistiladas em espigas, eretas, $4-9 \mathrm{~cm}$ compr.; flores isoladas, sésseis, amareladas a castanhoescuras, glabras a pilosas, bráctea e profilo linear-lanceolados, ca. $2 \mathrm{~mm}$ compr.; flores com perianto campanulado, amarelo-esverdeado; tépalas externas e internas oblongo-lanceoladas, acuminadas, 0,9-1,1 mm compr., unidas até a metade da sua altura; gineceu tricarpelar, crasso no terço inferior, depois tripartido, ramos bífidos no ápice; estaminódios 3, globosos, amarelados, inseridos na base ou a $1 / 3$ da altura das tépalas, ca. $0,5 \mathrm{~mm}$ compr. Cápsulas $1-2,1 \mathrm{~cm}$ compr., obovadas a oblongas; valvas cartáceas, amareladas, com pequenos e escassos pontos avermelhados e restos do perigônio 


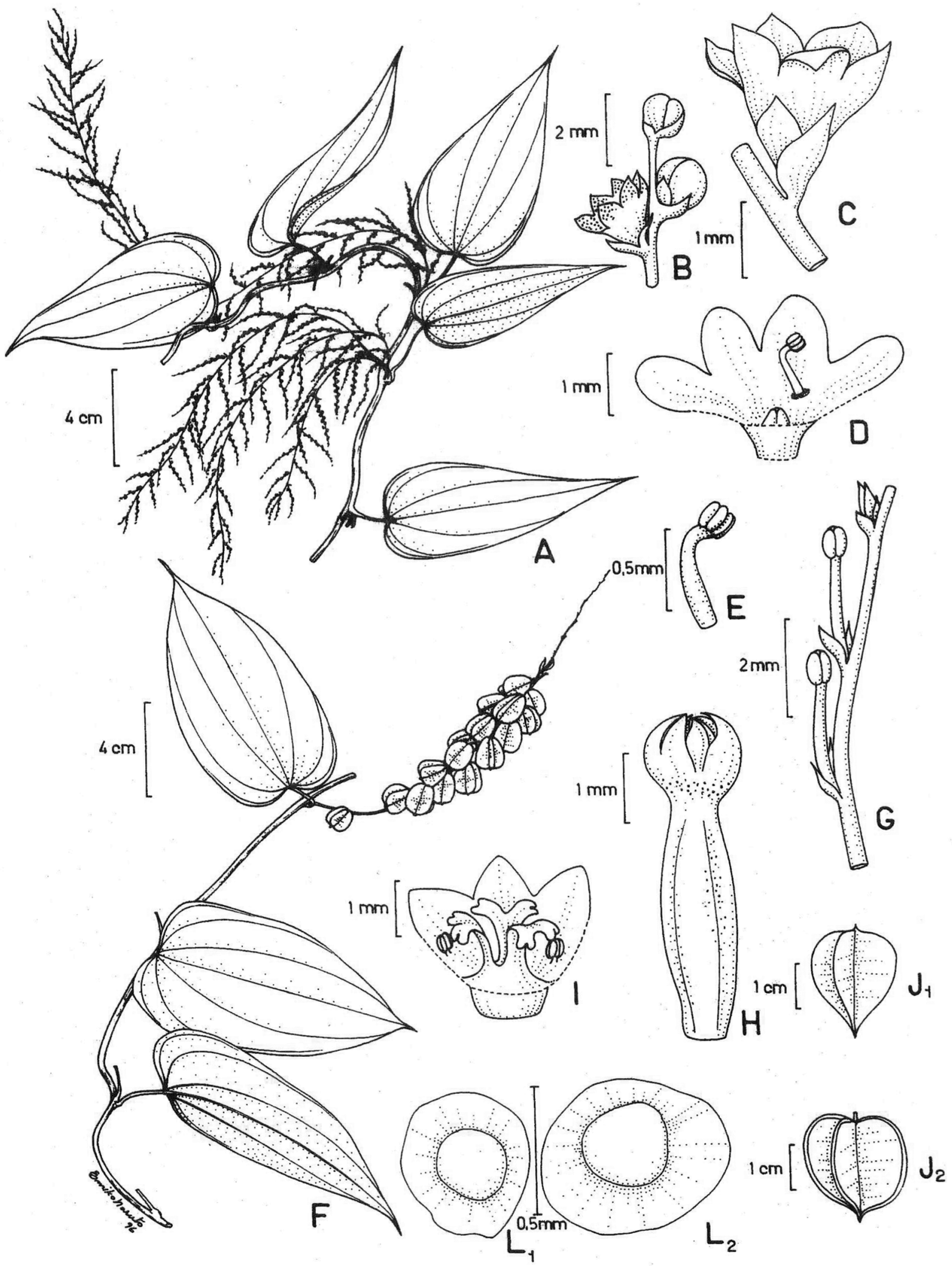

Fig. 3: Dioscorea amaranthoides Presl. A. ramo florífero (planta masculina); B-E. flor estaminada; B. flores em início da antese; C. flor em antese, bráctea e profilo; D. perigônio, estame e pistilódio; E. estame; F. ramo florífero (planta feminina); G-I. flor pistilada; G. flores jovens, brácteas e profilos; H. flor em antese; I. perigônio, estaminódios, estilete e estigma; J1-J2. cápsulas; L1-L2. sementes. (A-E: Pedralli s.n.; F-L2: Williams E Assis 6072) 
no ápice; margens espessadas. Sementes ca. $0,9 \mathrm{~mm}$ compr., circulares, aladas, brilhantes, alaranjadas, ásperas.

Material examinado: Minas Gerais: Santa Bárbara, Parque Natural do Caraça, Serra de São Gonçalo, VIII.1897, Schwacke 12809, fl. masc. (RB); Belo Horizonte, Jardim Botânico, 29.V.1934, H. Mello Barreto 2408 (BHMH). Belo Horizonte, 23.III.1935, H. Mello Barreto 4423, fl. fem., fr. (R); Santana do Riacho, Serra do Cipó, margem direita do rio Cipó, próximo à Pousada Monjolos, 16.IX.1997, G. Pedralli s.n., fl. masc. (HXBH).

Distribuição geográfica e hábitats: com distribuição neotropical mas restrita à América do Sul, na Cadeia do Espinhaço é encontrada em capões de mata e florestas estacionais (mesófilas) em solos pedregosos e arenosos, nos cerrados e florestas de galeria adjacentes aos campos rupestres cresce em solos aluvionais de baixa fertilidade. É uma liana umbrófila, que a partir de $1,0 \mathrm{~m}$ de altura torna-se apoiante sobre os indivíduos herbáceos no interior das florestas. Nos cerrados, sempre é apoiante sobre arbustos e ervas próximas.

Dioscorea amaranthoides distribui-se no Brasil desde as florestas e campinas amazônicas até o sul em São Paulo, em florestas estacionais (mesófilas), florestas de galeria e cerrados. A espécie ocorre, ainda, no Peru e Paraguai, sendo cultivada na Escócia e Inglaterra.

3. Dioscorea anomala (Kunth) Griseb. in Mart. \& Eichl., Fl. bras. 3(1): 31. 1842.

Tipo: "Brasilien, habitat in graminosis Serra da Lapa", Riedel 1004, pl. masc. (Holótipo B!; Isótipo P!).

Fig. 4

Plantas dióicas. Sistema subterrâneo constituído por rizóforo pequeno (ca. $3 \mathrm{~cm}$ compr.), profundo, com tuberosidade única, carnosa, irregular, da qual nascem raízes fibrosas; periderme acinzentada e medula branco-amarelada. Ervas anuais, com caules eretos, esverdeados a castanho-amarelados, $10-50 \mathrm{~cm}$ compr., glabros, ca. $2 \mathrm{~mm}$ diâm. Caules jovens em seção transversal aplanados a quase circulares, estriados, quando mais velhos quadrangulares, cobertos por pontuações avermelhadas distribuídas irregularmente na base; nós inferiores áfilos. Folhas simples, alternas a opostas, $3-11 \mathrm{~cm}$ compr., lineares, comprimidas, cartáceas, glabras, esverdeadas a amarelo-brilhantes em ambas as faces; pecíolos canaliculados, $0,3-1 \mathrm{~cm}$ compr., trinérveas, nervuras amareladas a marrom-escuras. Inflorescências estaminadas racemosas, $2-11 \mathrm{~cm}$ compr.; flores 2-3 por nó, ou, ainda, isoladas; bráctea oblonga a linear-acuminada, 2$3 \mathrm{~mm}$ compr., branco-amarelada; profilos oblongo-acu- minados, 2-3mm compr., alvas. Flores com perianto campanulado, amarelado, tépalas internas e externas elíptico-oblongas, 0,9-1,1 mm compr.; estames 6 , inseridos na base de cada tépala e inclusos no tubo; anteras ca. $0,4 \mathrm{~mm}$ compr., introrsas, ovaladas, deiscência longitudinal; filetes $1,4 \mathrm{~mm}$ compr., achatados e pouco mais longos na base, cilíndricos no terço superior; pistilódio cônico, $0,3 \mathrm{~mm}$ compr., inteiro. Inflorescências pistiladas em espigas, eretas, $2-10 \mathrm{~cm}$ compr.; flores isoladas em cada nó floral, sésseis, com bráctea na base, oblongo-lanceolada, ca. $3 \mathrm{~mm}$ compr.; flores com perianto campanulado, branco-amarelado; tépalas externas e internas oblongo-lanceoladas, 3-3,5mm compr., unidas desde a base; gineceu tricarpelar, estiletes unidos, colunar, crasso, livres no ápice, ramos bífidos; estaminódios 6, amarelados, na base de cada tépala, ca. $0,8 \mathrm{~mm}$ compr. Cápsulas $0,9-1,3 \mathrm{~cm}$ compr., oblongas a obovadas, amareladas, alaranjadas a castanho-escuras; após secas com as valvas alaranjado-escuras, pontuações escuras distribuídas irregularmente nas valvas e restos do perigônio no ápice; margens espessadas. Sementes ca. $0,7 \mathrm{~mm}$ compr., elípticas, aladas, ala circular, alaranjado-escuras, rugosas.

Material examinado: Minas Gerais: Santana do Riacho, Serra do Cipó, estrada para Conceição do Mato Dentro, 1935, Brade 14884, fl. masc. (B); Santana do Riacho, Serra do Cipó, 30.X.1936, H. Mello Barreto 9273 (BHMH); Santana do Riacho, Serra do Cipó, 1938, J. Badini 2038, fl. fem., fr. (UFOP); Santana do Riacho, Serra do Cipó, 20.XI.1952, G.M. Magathães 1952 (VIC); Santana do Riacho, Serra do Cipó, 12.XI. 1959, E.P. Heringer 7353, fl. fem., fr. (UB); Jaboticatubas, Serra do Cipó, 21.XI.1965, G. Eiten $\mathcal{E} ~ L$. Eiten 675.5, fl. masc. (SP, K); Santana do Riacho, Serra do Cipó, 17.II.1968, H.S. Irwin et al. 20384, fr. (UB); Santana do Riacho, Serra do Cipó, km 142, estrada Belo Horizonte-Conceição do Mato Dentro, 14.XII.1971, J. Semir E I. Sazima 529, fl. masc. (UEC); Santana do Riacho, Serra do Cipó, 17.II.1972, W. Anderson et al. 36082, fr. (UB); Jaboticatubas, 3.XI.1978, J. Semir 8656a, fl. masc. (UEC); Jaboticatubas, 3.XI.1978, J. Semir 8656b, fl. fem., fr. (UEC); Santana do Riacho, Serra do Cipó, Morro do Palácio, 7.XI.1980, I. Cordeiro et al. s.n., fl. masc. (SPF, SP, K); Santana do Riacho, cachoeira no rio Capivara, 16.XII. 1980, J.R. Pirani et al. 21318 , p.p., fl. masc. (SPF, SP, K, F); Santana do Riacho, cachoeira no rio Capivara, 16.XII.1980, J.R. Pirani et al. 21318, p.p., fl. fem. (SPF, SP, K. F); Santana do Riacho, Serra do Cipó, km 129 da rodovia Belo Horizonte-Conceição do Mato Dentro, 6.X.1981, I. Cordeiro et al. 7538, fl. masc. (SPF, SP, K); km 138, Santana do Riacho, Serra do Cipó, 30.X.1981, M.G. Sajo Ẽ N.M. Castro s.n., fl. masc. (SPF, SP, RB); Congonhas do Norte, Riacho do Barbado, J.R. Pirani et al. 8384 (SPF); Santana do Riacho, Serra do Cipó, km 129 da estrada Belo Horizonte-Conceição do Mato Dentro, 6.X.1981, I. Cordeiro et al. 20339 (SPF, SP, K); Congo- 


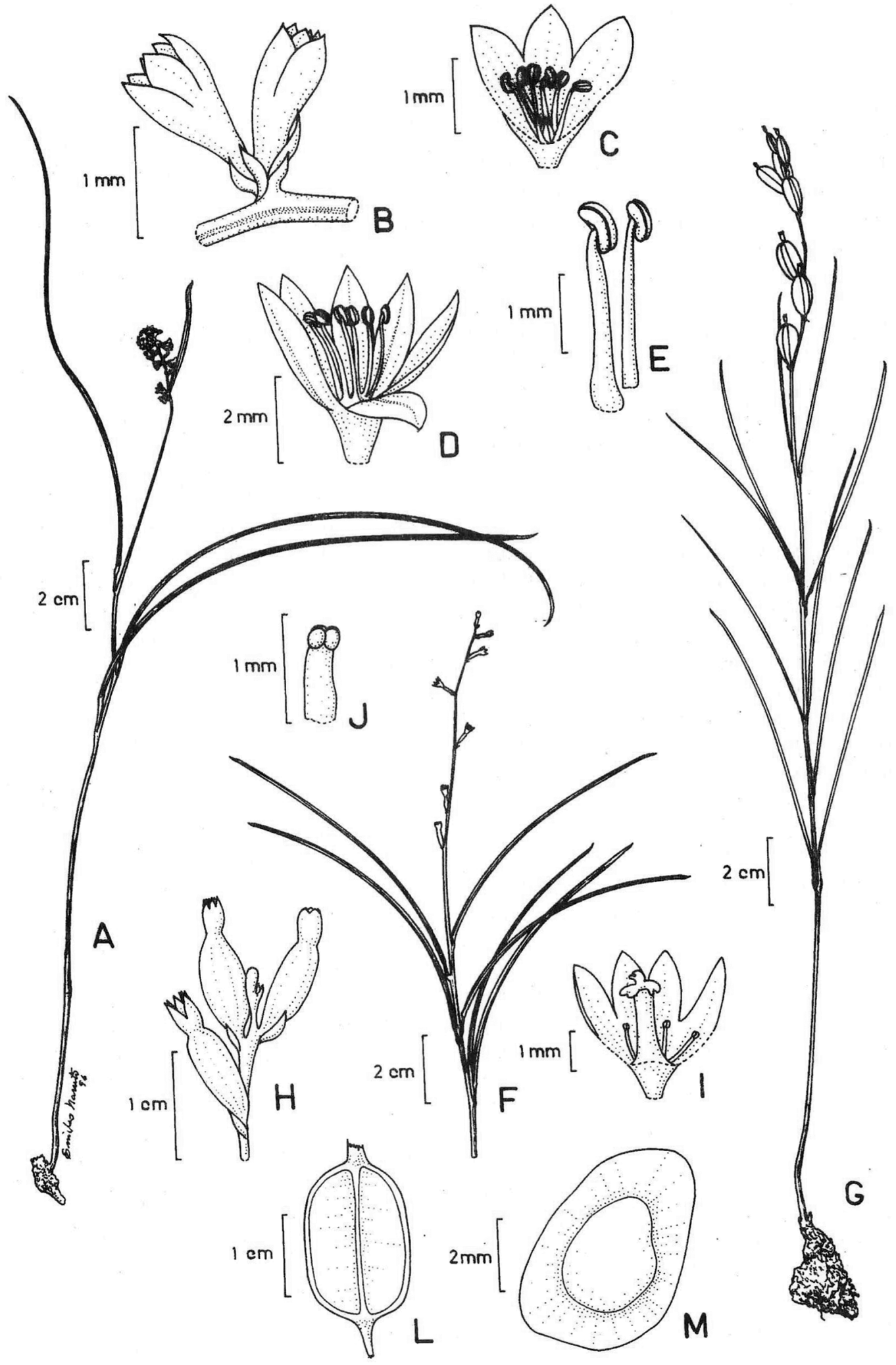

Fig. 4: Dioscorea anomala (Kunth) Griseb. A. ramo florifero (planta masculina); B-E. flor estaminada; B. flores em antese, brácteas e profilos; C. perigônio, estames e pistilódio; D. perigônio e estames (flor sem pistilódio); E. estames; F. ramo florífero (planta feminina); G. planta em frutificação e sistema subterrâneo (rizóforo); H-J. flor pistilada; H. flores em antese e brácteas; I. perigônio, estaminódios, estilete e estigma; J. estaminódio; L. cápsula; M. semente. (A-E: Cordeiro et al. 7538; F-J: Godoy et al. 10758; L-M: Anderson et al. 36082) 
nhas do Norte, Retiro do Barbado, 22.IV.1982, M. Amaral et al. s.n. (SPF); Santana do Riacho, Serra do Cipó, estrada Belo Horizonte-Conceição do Mato Dentro, 15.XI.1984, M.G. Arrais et al. 35097, p.p., fl. masc. (SPF, SP, K); Santana do Riacho, Serra do Cipó, estrada Belo Horizonte-Conceição do Mato Dentro, 15.XI.1984, M.G. Arrais et al. 35097 pr.p., fr. (SPF, SP, K); Santana do Riacho, Serra do Cipó, km 125 da rodovia Belo Horizonte-Conceição do Mato Dentro, 1.XI.1985, Gonçalves et al. 9395 (SPF, SP); Santana do Riacho, Serra do Cipó, 2.II.1987, F. Barros 1328, fl. masc. (SP); Santana do Riacho, Serra do Cipó, bifurcação para Morro do Pilar, 9.X.1987, S. Godoy et al. 10758, fl. fem. (SPF, SP); Santana do Riacho, Serra do Cipó, $26 \mathrm{~km}$ ao sul de Conceição do Mato Dentro, 23.X.1988, R.M. Harley et al. 25418, fl. masc. (SPF, K); Santana do Riacho, Serra do Cipó, Juquinha, 27.XI.1991, L. Parra et al. 12877, fl. masc. (SPF); sem local, 1829, Riedel s.n., pl. masc. (OXF); Santana do Riacho, Serra do Cipó, Alto do Palácio, portaria do IBAMA, 16.XI.1995,J. Lombardi 1020, fl. masc. (BHCB, HXBH).

Distribuição geográfica e hábitats: com distribuição neotropical mas restrita ao Brasil, na Cadeia do Espinhaço ocorre em locais úmidos, próximo a brejos estacionais ou perenes, em solos pedregosos, pobres, ou, ainda, em locais abertos, bem drenados e em fendas nos afloramentos rochosos nos campos rupestres.

Dioscorea anomala distribui-se pelos campos rupestres de Goiás e Minas Gerais, sempre em locais abertos e em afloramentos rochosos, em solos pedregosos ou arenosos.

4. Dioscorea bulbifera L., Sp. pl., ed. 2 p. 1033. 1753. Tipo: Rhede, Horti Malabarici 7: 69, tab. 36. 1688. Ilustração do hábito com "bulbilhos" e frutos (Lectótipo). Fig. 5

Plantas dióicas. Sistema subterrâneo constituído por rizóforos curtos (ca. $5 \mathrm{~cm}$ compr.) e partes espessadas achatadas, profundos ou sob camadas delgadas de folhas em fendas nas rochas, ovaladas, com formato irregular, ou, ainda, palmatiformes, de onde se originam pequenas raízes; periderme acinzentado-escura, medula branco-amarelada. Nas plantas mais velhas podem ocorrer bulbilhos aéreos, que nascem na axila das folhas. As plantas apresentam, em geral, uma tuberosidade principal, arredondada ou alongada, que pode pesar até $2 \mathrm{~kg}$. Lianas anuais, com ramos amarelados a esverdeados, dextrogiros, sulcados, sem expansões laterais, com $12 \mathrm{~cm}$ a $2 \mathrm{~m}$ compr., glabros a pubérulos, 1$4 \mathrm{~mm}$ diâm. Caules jovens em seção transversal circulares, quando velhos circulares a pentagonais, glabros, castanho-escuros. Folhas alternas, $2-15 \mathrm{~cm}$ compr., esverdeadas, oliváceas a castanho-escuras, polimorfas, ovadas, elípticas, deltóides, acuminadas, cordadas a sagitadas, apiculadas, cartáceas, glabras, com pontuações avermelhadas ou escuras no limbo, 5-9 nervuras salientes, pecíolos 0,5-14cm compr., canaliculados nas folhas velhas, cilíndricos e delicados nas folhas jovens. Inf lorescências estaminadas em racemos, ca. $12 \mathrm{~cm}$ compr.; flores sésseis, 1-3 em cada nó floral, bráctea na base, alva, linear-acuminada, $2 \mathrm{~mm}$ compr., perianto campanulado; 6 estames, inseridos na base das tépalas, mais curtos que estas; filetes ca. $2 \mathrm{~mm}$ compr., unidos na base; pistilódio cilíndrico, retuso no ápice, com 3 ramos divergentes. Inflorescências pistiladas em espigas, pêndulas, $1-5,3 \mathrm{~cm}$ compr.; flores $2-3$ ou isoladas em cada nó floral, sésseis; bráctea e profilo na base, amarelados, oblongo-acuminados, 1-1,3mm compr., com pontuações avermelhadas; perianto campanulado, amarelado; tépalas externas e internas ovadas, ca. $1,6 \mathrm{~mm}$ compr., unidas desde a base até a metade da sua altura; gineceu tricarpelar, crasso, colunar, base dilatada, depois cilíndrico, estiletes 3 , livres no $1 / 3$ superior, ramos bífidos no ápice; estaminódios 6 , na base das tépalas, amarelados, elípticos, ca. $0,2 \mathrm{~mm}$ compr. Cápsulas $0,7-1 \mathrm{~cm}$ compr., amareladas, cartáceas, obovadas, com restos do perigônio no ápice; valvas rugosas, glabras, margens simples a levemente engrossadas. Sementes ca. $7 \mathrm{~mm}$ compr., elípticas, escuras, com ala cartácea, expandida em direção ao ápice.

Material examinado: Bahia: Lençóis, Pai Inácio, 17.VII. 1986, G. Pedralli Ẽ G.P. Silva 2616, fl. masc. (CEN, HXBH); Palmeiras, Pai Inácio, a $9 \mathrm{~km}$ da entrada para Lençóis, 17.VII.1986, G. Pedralli E G.P. Silva 2617, fl. fem., fr. (CEN, $\mathrm{HXBH})$. Minas Gerais: Belo Horizonte, Horto da Universidade Federal de Minas Gerais, 5.IX.1986, Ferrari 128 (BHCB); Ouro Preto, Estação Ecológica do Tripuí, próximo à residência do Sr. João Lopes, 19.IV.1994, G. Pedralli Ẽ Teixeira s.n., fl. masc. (HXBH).

Distribuição geográfica, hábitats e variabilidade: a espécie possui distribuição pantropical, tendo-se originado na Ásia, mais especificamente na Indo-Malásia, de onde se difundiu pelo cultivo, para alimentação humana, para o Japão, sul do Pacífico, oeste da África, América Central e Caribe, e América do Sul. Os materiais encontrados na Chapada Diamantina, em condição subespontânea, possuem caracteres semelhantes aos encontrados nos materiais da Indonésia e África, especialmente com relação ao sistema subterrâneo. A forma das tuberosidades, semelhantes a uma "mão" é um dos caracteres presentes nos materiais mais rústicos daquelas regiões, e que está presente nos materiais da Cadeia do Espinhaço, que mantiveram as características fenotípicas.

As populações silvestres de D. bulbifera ocorrem na orla e interior de florestas estacionais (mesófilas), nos ambientes abertos das caatingas e cerrados, em solos 


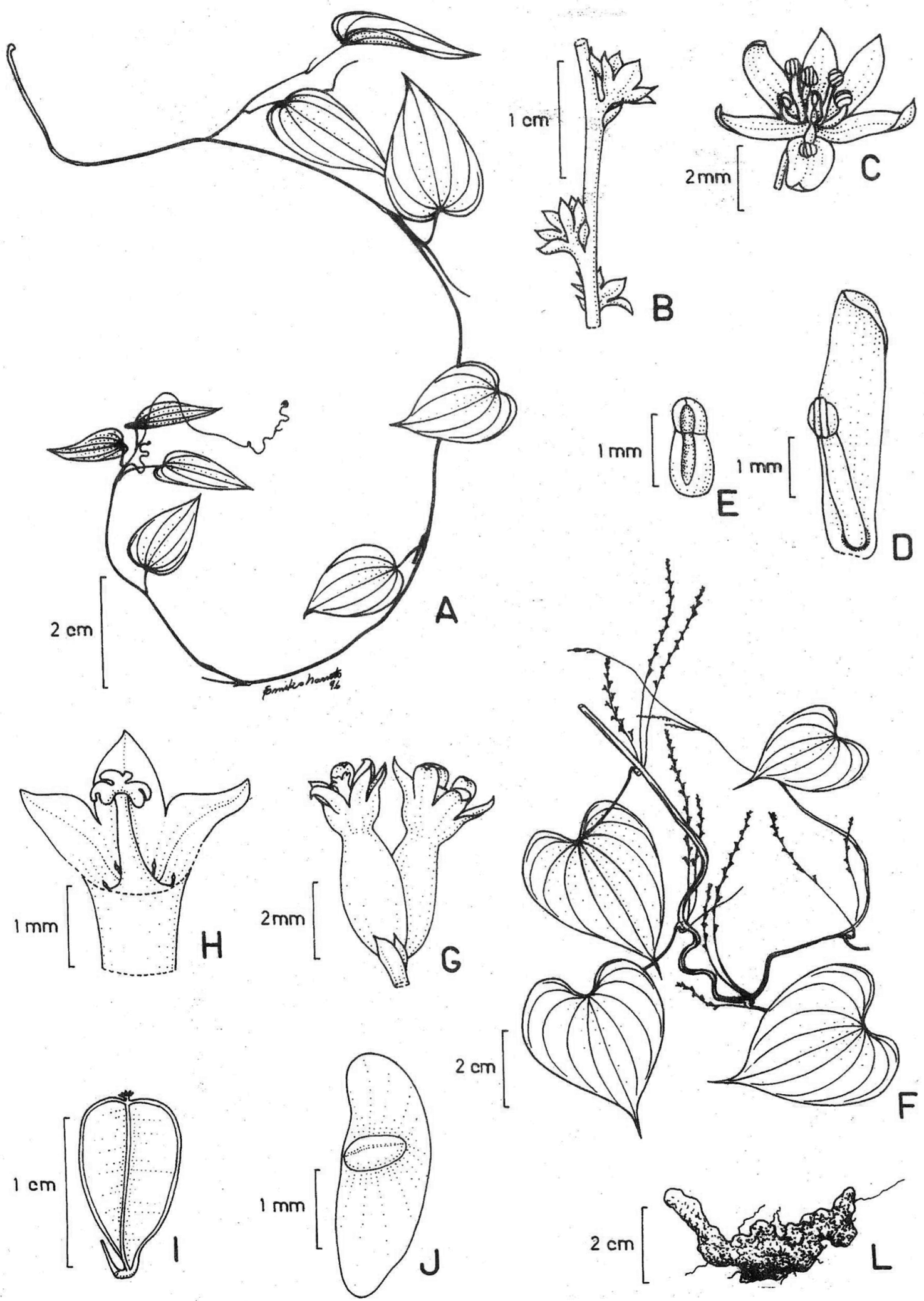

Fig. 5: Dioscorea bulbifera L. A. ramo florífero (planta masculina); B-E. flor estaminada; B. flores em antese e brácteas; C. perigônio, estames e pistilódio; D. tépala e estame; E. pistilódio; F. ramo florífero (planta feminina); G-H. flor pistilada; G. flores em antese, bráctea e profilo; H. perigônio, estaminódios, estilete e estigma; I. cápsula; J. semente; L. sistema subterrâneo (tuberosidade). (A-E, L: Pedralli E゚ Silva 2616; F-J: Pedralli E Silva 2617) 
argilosos a arenosos, e também em afloramentos rochosos nos campos rupestres da Cadeia do Espinhaço.

5. Dioscorea campestris Griseb. in Mart. \& Eichl., Fl. bras. 3(1): 30.1842.

Tipo: Brasil, "Habitat in provinciae Minarum generalium campis editis, ubi inter herbas scandit", Martius 40, pl. masc. (Lectótipo M!).

Fig. 6

Plantas dióicas. Sistema subterrâneo constituído por rizóforos com 1,5 a 3cm compr., porção espessada curta, levemente engrossada e irregular; periderme branco-amarelada e medula marrom-escura. Lianas, com ramos perenes, amarelados, esverdeados a castanhoescuros, dextrogiros, estriados, sem expansões laterais, glabros, $20-60 \mathrm{~cm}$ compr., 0,5-2 $\mathrm{mm}$ diâm. Caules jovens em seção transversal circulares, os velhos elípticos, pentagonais a poligonais, brilhantes, canaliculados. Folhas alternas, ovadas a elíptico-lanceoladas, acuminadas, cordadas, com lobos basais arredondados, cartáceas, glabras, esverdeadas a castanho-escuras, com 9 nervuras salientes em ambas as faces e pontuações avermelhadas, 2,5-7,5cm compr.; pecíolos robustos, achatados, glabros, encurvados na base, ca. $1,0 \mathrm{~cm}$ compr. Inflorescências estaminadas racemosas, $6-12 \mathrm{~cm}$ compr., flores $1-3 \mathrm{em}$ cada nó floral; bráctea ovada a linear-lanceolada, 0,5$1 \mathrm{~mm}$ compr.; flores com perianto campanulado, amarelado a castanho-escuro; tépalas internas e externas obovadas, 1,6mm compr., com lobos reflexos; estames 6 , inseridos na base de cada tépala; anteras ca. $0,5 \mathrm{~mm}$ compr., extrorsas, elíptico-alongadas, deiscência longitudinal, filetes ca. $1 \mathrm{~mm}$ compr., achatados e concrescidos na base, depois cilíndricos até a inserção das anteras, encurvados; pistilódio ausente. Inflorescências pistiladas em espigas, pêndulas, $4-12 \mathrm{~cm}$ compr.; flores sésseis, perianto campanulado, amarelado a castanhoescuro, com bráctea e profilo oblongos a ovado-acuminados, ca. $1 \mathrm{~mm}$ compr.; tépalas internas e externas ovado-acuminadas, 1-1,5mm compr.; gineceu tricarpelar, colunar, mais grosso na base, estiletes 3 , unidos na base, livres no terço superior, ramos simples; estaminódios 6 , amarelados, oblongos, ca. 0,5mm compr., curvados para o interior do tubo. Cápsulas ca. $1,5 \mathrm{~cm}$ compr., branco-amareladas, elípticas, glabras; valvas membranáceas, margens dilatadas, com restos do perigônio no ápice. Sementes centrais, circular-ovóides, ca. $3 \mathrm{~mm}$ compr., escuras, lisas, com ala reduzida.

Material examinado: Bahia: Jacobina, 28.VI.1983, L. Coradin et al. 6179, fl. fem., fr. (CEN). Minas Gerais: Belo Horizonte, Barro Preto, 12.XII.1918, Gehrt 3194, fl. masc. (SP); Grão-Mogol, 12.XI.1938, H. Mello Barreto et al. 12 163, fl. masc. (BHMH); Itabirito, 7.II.1968, H.S. Irwin et al. 19545, fl. masc.
(UB); Santana do Riacho, Serra do Cipó, 16.II.1968, H.S. Irwin et al. 20242, fl. masc. (UB); Mariana, Parque Estadual do Itacolomi, a $2 \mathrm{~km}$ do pico, 30.I.1971, H.S. Irwin et al. 29398, fl. masc. (UB); Diamantina, rio Jequiti, estrada para Mendanha, 15.IV.1973, W. Anderson 8978, fl. masc. (UB); Grão Mogol, 13.IV.1981, I. Cordeiro et al 789, fl. masc. (SPF, SP); Ouro Preto, Estação Ecológica do Tripuí, 30.I.1993, G. Pedralli 3384, fl. masc. (HXBH); Joaquim Felício, Serra do Cabral, 4.XI.1993, G. Pedralli $\mathcal{E}$ Teixeira 3432, fl. masc. (HXBH); Ouro Preto, Parque Estadual do Itacolomi, 9.XI.1993, Teixeira $\mathcal{E}^{\mathcal{O}}$ Oliveira s.n., fl. masc. (HXBH); Mariana, Parque Estadual do Itacolomi, trilha para o pico, 15.XII.1993, Teixeira $\mathcal{E}^{\circ}$ Oliveira s.n., fl. masc. (HXBH); Caeté, Serra da Piedade [non Lagoa Santa], sem data, Warming s.n., fl. fem., fr. (B); Ouro Preto, Estação Ecológica do Tripuí, sem data, Damazio s.n, fl. masc. (RB).

Distribuição geográfica e hábitats: a espécie, com distribuição neotropical e exclusiva da América do Sul, tem ampla distribuição geográfica no Brasil, desde o Amazonas passando pelo Nordeste, Centro-Oeste e Sudeste até o Sul no Rio Grande do Sul. Ocorre, ainda, na Argentina e no Paraguai.

Dioscorea campestris ocorre na borda de florestas pluviais, especialmente em florestas de galeria e em áreas de transição na Cadeia do Espinhaço, entre os capões de mata e os campos rupestres. Ocorre, também, na orla das florestas estacionais (mesófilas), na caatinga arbórea e nos cerrados brasileiros.

6. Dioscorea cinnamomifolia Hook., Curtis's Botanical Magazine 2: tab. 2825. 1828.

Tipo: Curti's Botanical Magazine 2, tab. 2825, ilustração de planta masculina (Lectótipo).

Fig. 7

Plantas dióicas. Sistema subterrâneo constituído por um rizóforo curto (ca. $2 \mathrm{~cm}$ compr.), profundo, em cuja extremidade se pode observar uma tuberosidade umbo-nada, com a base convexa e fendas longitudinais estreitas, da qual se originam raízes longas, ca. $50 \mathrm{~cm}$ compr., simples. Da gema central desta tuberosidade, crescem os novos ramos a cada ano. Os rizóforos podem também crescer no sentido horizontal, formandose, então, tuberosidades com ca. $70 \mathrm{~cm}$ diâm.; periderme acinzentada a marrom-escura e medula branca a marrom-escura. Lianas com ramos perenes, amarelados, esverdeados a castanho-escuros, sinistrogiros, sem expansões laterais, apoiantes, $0,2-8 \mathrm{~m}$ compr., glabros a tomentosos no ponto de inserção das folhas, ca. $1 \mathrm{~mm}$ diâm. Caules jovens triangulares, com pequenos acúleos, "alados"; quando mais velhos em seção transversal circulares, castanho-escuros na base. Folhas alternas, cartáceas a membranáceas, elíptico-lanceoladas, 


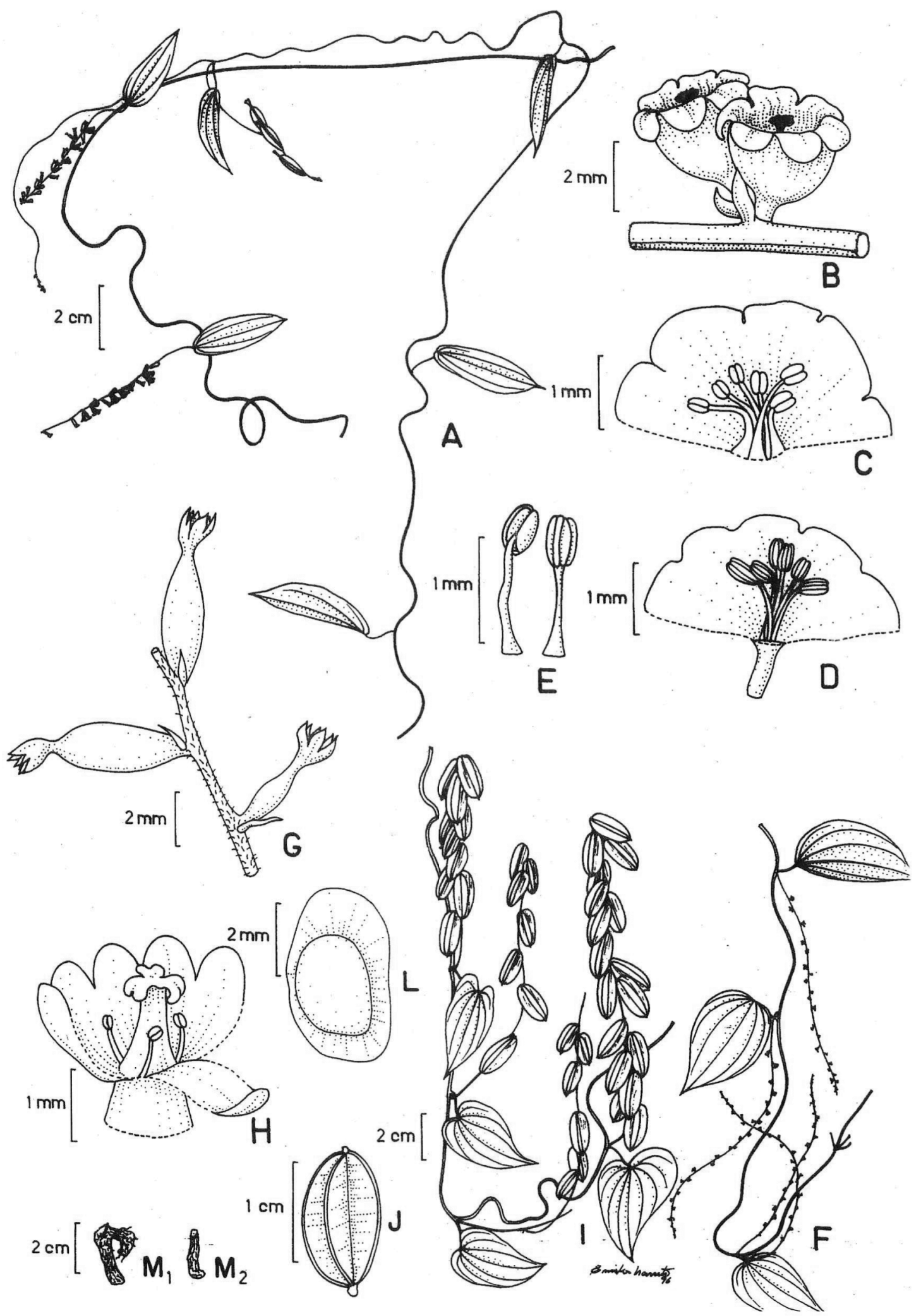

Fig. 6: Dioscorea campestris Griseb. A. ramo florífero (planta masculina); B-E. flor estaminada; B. flores em antese, bráctea e profilo; C-D. perigônio e estames; E. estames; F. ramo florífero (planta feminina); G-H. flor pistilada; G. flores em antese e brácteas; H. perigônio, estaminódios, estilete e estigma; I. ramo em frutificação; J. cápsula; L. semente; M1-M2. sistema subterrâneo (tuberosidades). (A-E: Pedralli 3384; F-M2: L. Coradin et al. 6179) 

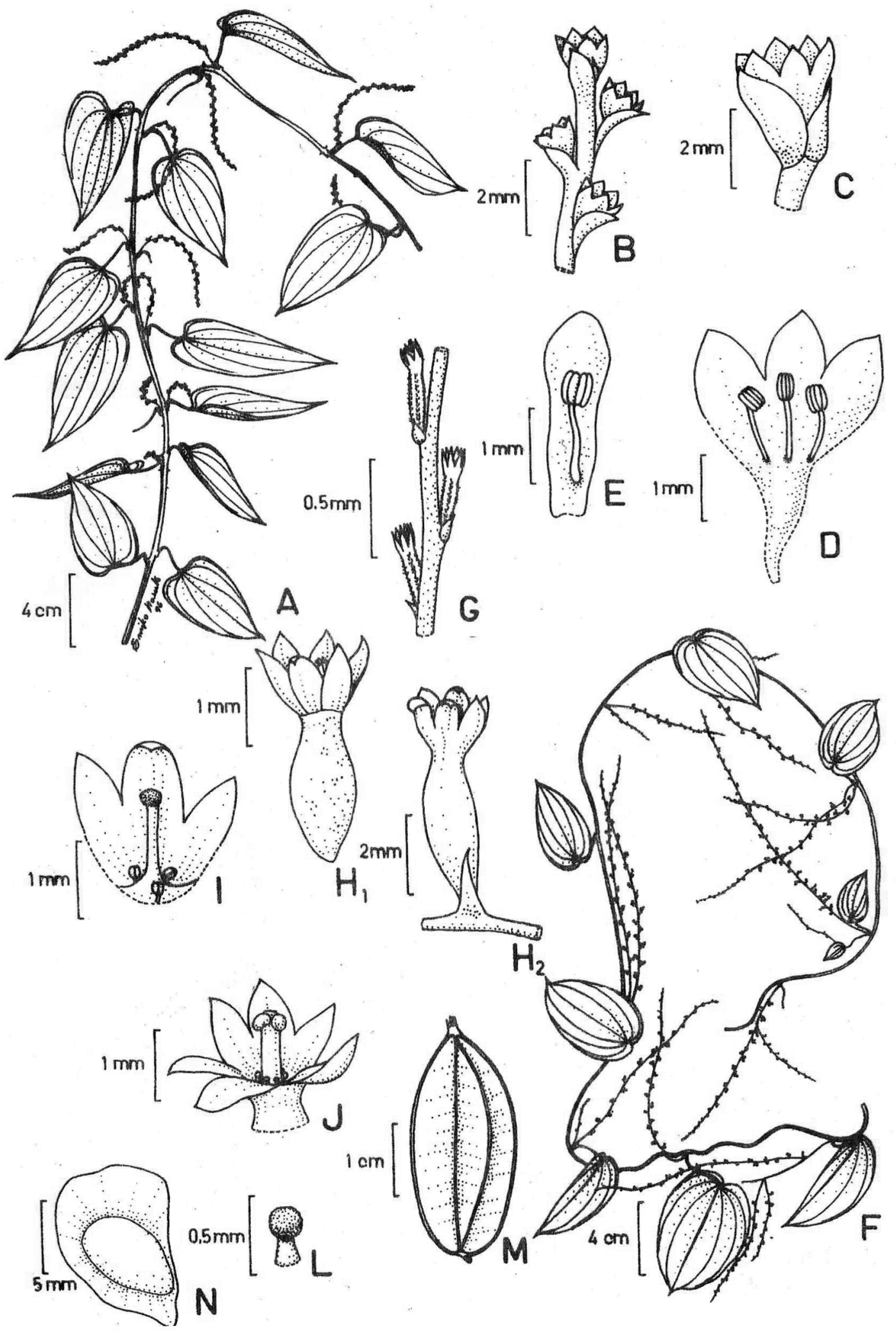

Fig. 7: Dioscorea cinnamomifolia Hook. A. ramo florífero (planta masculina); B-E. flor estaminada; B. flores em antese, brácteas e profilo; C. flor em antese, bráctea e profilo; D. tépalas e estames; E. tépala e estame; F. ramo florífero (planta feminina); G-L. flor pistilada; G. flores jovens pilosas e brácteas; H1-H2. flores em antese e bráctea; I. tépalas, estaminódios, estilete e estigma; J. perigônio, estaminódios, estilete e estigma; L. estaminódio; M. cápsula; N. semente. (A-E: Mamede el al. 6264; F-N: Gehrt 3192) 
atenuadas a cordadas, glabras, esverdeadas a avermelhadas, com pontuações avermelhadas dispersas no limbo, 7-9 nervuras patentes, sendo as três centrais mais evidentes, $2,5-10 \mathrm{~cm}$ compr.; pecíolos retorcidos, canaliculados, glabros, amarelados a castanho-escuros, 0,5$5 \mathrm{~cm}$ compr. Inf lorescências estaminadas racemosas, 3$18 \mathrm{~cm}$ compr., flores $1-2$ por nó, bráctea e profilo com pontuações avermelhadas na base; flores com perianto campanulado, amarelado a castanho-escuro; tépalas internas e externas ovadas, 1,5-2mm compr.; estames 6 , inseridos na base ou a 1/3 da altura das tépalas; anteras ca. $0,4 \mathrm{~mm}$ compr., lateral-extrorsas, elíptico-quadrangulares, deiscência longitudinal, filetes $0,2-1,5 \mathrm{~mm}$ compr., achatados até a inserção das anteras, retos a levemente curvados; pistilódio ausente. Inflorescências pistiladas em espigas, pêndulas, $7-10 \mathrm{~cm}$ compr.; flores com perianto campanulado, amarelado a castanho-escuro, isoladas em cada nó floral, sésseis, glabras, com bráctea triangular-lanceolada, ca. 1,8mm compr.; tépalas internas e externas ovado-elípticas, 1,9-2,3mm compr., hialinas; gineceu tricarpelar, colunar, crasso, estiletes 3 unidos nos 2/3 inferiores, livres no ápice, ramos simples, globosos, rugosos; estaminódios 6 , amarelados, com filetes curtos, globosos no ápice, inseridos na base do estilete, ca. 0,3mm compr. Cápsulas 1,5$3 \mathrm{~cm}$ compr., elípticas, glabras, cartáceas; valvas amareladas a castanho-escuras, apiculadas, com restos do perigônio no ápice, margens dilatadas. Sementes ca. 1 cm compr., obovadas, marrom-escuras, ala basal amarelada a alaranjada, circular.

Material examinado: Bahia: Mucujê, 25.I.1980, R.M. Harley et al. 20582, fl. masc. (SPF). Minas Gerais: Belo Horizonte, 1919, Gehrt 3192, fl. fem., fr. (B); Belo Horizonte, Jardim Botânico, 1.IV.1934, H. Mello Barreto 2401, fl. masc. (BHMH); Belo Horizonte, Jardim Botânico, 12.II.1944, H. Mello Barreto 2402, fl. masc. (R); Diamantina, estrada da Extração, 20.XI.1984, M.C. Mamede et al. 6264, fl. masc. (SPF, SP, K); Nova Lima, sítio do João Renato, 18.IV.1987, J.R. Stehmann s.n. (HXBH); Grão Mogol, morro perto do riacho Ribeirão, 3.XI.1987, R. Mello Silva et al. 11400, fl. masc. (SPF, SP); Caeté, Serra de Piedade, sem data, Warming 1879, p.p., fl. masc. (P); Caeté, Serra de Piedade, sem data, Warming s.n., fl. masc. (C, B).

Distribuição geográfica e hábitats: a espécie apresenta distribuição neotropical e exclusiva da América do Sul, e na Cadeia do Espinhaço ocorre em locais abertos, em afloramentos rochosos e em solos pedregosos entre pequenos arbustos nos campos rupestres. Também habita a borda das florestas estacionais (mesófilas) e florestas de galeria próximas a estes campos.

Dioscorea cinnamomifolia tem distribuição geográfica no Brasil desde a Bahia até Santa Catarina, em solos arenosos das restingas e na Floresta Atlântica de encosta, além de atingir a Argentina e Paraguai.

7. Dioscorea demourae R. Knuth, Notizbl. Bot. Gart. Mus. Berlin 7(65): 199. 1917.

Tipo: "Brasilien, Staat Rio de Janeiro, Theresopolis", De Moura 535, planta monóica (Holótipo B!).

Fig. 8

Plantas monóicas. Sistema subterrâneo constituído por um rizóforo curto (ca. $1 \mathrm{~cm}$ compr.) com presença de amido na medula, profundo, com tuberosidade na extremidade, discóide, aplanada, comprimida, carnosa, com ponto vegetativo central, da qual brotam raízes filiformes, escuras; periderme acinzentada e medula branco-amarelada. Lianas, com ramos perenes ou apoiantes, amarelo-esverdeados a castanho-escuros, sem expansões laterais, dextrogiros, 0,5-1m compr., glabros, com pontuações avermelhado-escuras distribuídas irregularmente, 0,3-1 mm diâm. Ramos jovens em seção transversal circulares, quando mais velhos circular-achatados, comprimidos, canaliculados, com até $2 \mathrm{~m}$ compr. Folhas alternas, ovadas a deltóides, esverdeadas, oliváceas a castanho-escuras, acuminadas, sagitadas com lobos arredondados e 'sinus' amplo, glabras, com pontuações avermelhadas esparsas, 7-11 nervuras salientes, 4-12cm compr., membranáceas; pecíolos filiformes, canaliculados, retorcidos, $1-3 \mathrm{~cm}$ compr. Inflorescências estaminadas racemosas, $6-18 \mathrm{~cm}$ compr.; flores isoladas, bráctea oblonga a linear-lanceolada na base, 0,5$1 \mathrm{~mm}$ compr.; flores com perianto rotado, amarelado a rosado-purpúreo; tépalas internas elíptico-lanceoladas, 5-5,8mm compr., tépalas externas obovadas, $6,5-6,8 \mathrm{~mm}$ compr.; estames 3, inseridos nos ângulos apicais do tubo estaminal cilíndrico, triangular, plano; anteras sésseis em cada segmento, extrorsas, coccíneas, oval-alongadas, ca. $0,9 \mathrm{~mm}$ compr., deiscência longitudinal; pistilódio ausente. Inflorescências pistiladas em espigas pêndulas, $5-12 \mathrm{~cm}$ compr.; flores com perianto campanulado, esverdeado, avermelhado a castanho-escuro, isoladas em cada nó floral, sésseis, pilosas, com bráctea e profilo oblongo-lanceolados, 1-2mm compr. Tépalas internas e externas ovadas, 1,7-2mm compr.; gineceu tricarpelar, estiletes 3, divergentes, soldados na base, crassos, inseridos no disco carnoso. Cápsulas 2-2,5 cm compr., elíptico-oblongas, glabras; valvas esverdeadas a marrom-escuras (ao vivo), com restos do perigônio no ápice, margens levemente dilatadas. Sementes ca. $10 \mathrm{~mm}$ compr., lisas, oval-circulares, castanho-escuras, com asa circular elipsóide, expandida em direção ao ápice do fruto.

Material examinado: Minas Gerais: Diamantina, São João da Chapada, 28.III.70, H.S. Irwin et al. 28448 , fl. masc. (UB); 


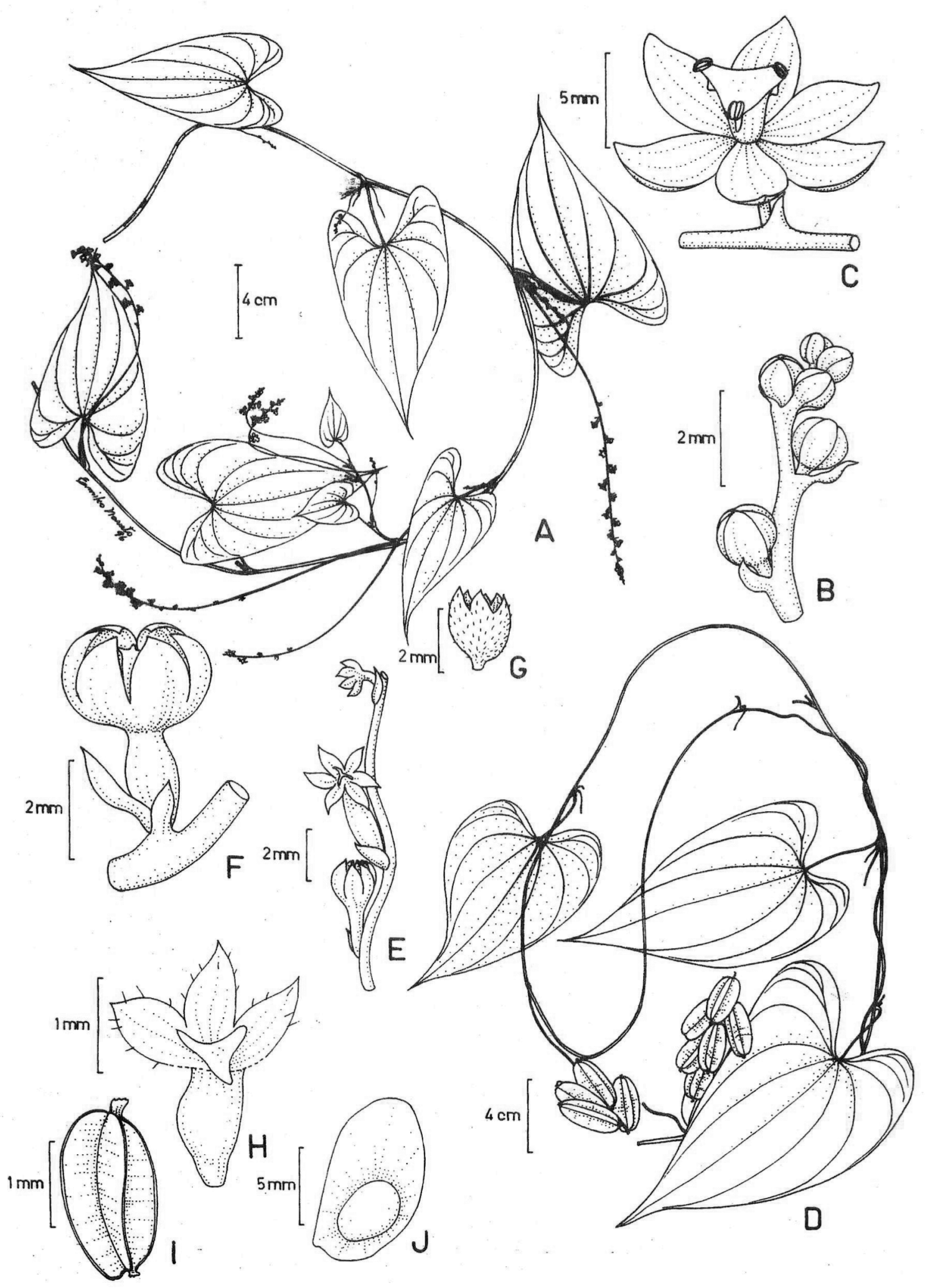

Fig. 8: Dioscorea demourae R. Knuth. A. ramo florífero (planta masculina); B-C. flor estaminada; B. flores jovens e brácteas; C. perigônio, coluna estaminal e anteras; D. ramo florífero (planta feminina); E-H. flor pistilada; E. flores em antese, brácteas e profilos; F. flor em antese, bráctea e profiro; G. flor pilosa; H. perigônio e estiletes; I. cápsula; J. semente. (A-C: Pedralli Đ̋ Teixeira s.n.; D-J: Pedralli 3385) 
Moeda, Serra da Moeda, 29.XI.1987, Pereira 11747, fl. masc. (BHCB); Tiradentes, Pedreira, estrada velha para Prados, 6.II.1993, G. Pedralli 3386, fl. masc. (HXBH); Tiradentes, APA da Serra de São José, 6.II.1993, G. Pedralli 3385, fl. fem., fr. (HXBH); Ouro Preto, Estação Ecológica do Tripuí, córrego Alto, 18.II.1994, G. Pedralli Ẽ Teixeira s. n., fl. masc. (HXBH); Ouro Preto, Estação Ecológica do Tripuí, próximo à Guarita, 4.III.1997, G. Pedralli et al. s.n., fl. masc. (HXBH).

Distribuição geográfica e hábitats: a espécie habita o interior da Floresta Atlântica e florestas de galeria nos estados do Sudeste e Sul, e no Distrito Federal e Minas Gerais. Ocorre, também, no interior de florestas estacionais (mesófilas) e florestas de galeria. Na Cadeia do Espinhaço ocorre nos campos rupestres em locais sombreados, em fendas e no interior de florestas estacionais (mesófilas), apresentando distribuição neotropical e exclusiva da América do Sul.

Dioscorea demourae tem ampla distribuição geográfica, tendo sido referenciada para os estados do Pará, Distrito Federal e para o sul, desde a Bahia e Minas Gerais até o Rio Grande do Sul. Ocorre, ainda, na Argentina, nas províncias de Corrientes, Chaco e Misiones.

8. Dioscorea dodecaneura Vell., Fl. flum. 10 (ícones): tab. 123. 1831, et in Archos. Mus. Nac. Rio de Janeiro 5: 426. 1881.

Tipo: Vellozo, Fl. flum. 10 (ícones): tab. 123, ilustração de planta masculina. (Lectótipo).

Fig. 9

Plantas dióicas. Sistema subterrâneo constituído por um longo rizóforo horizontal (ca. 50cm compr.), 1-2 cm de profundidade, próximo da superfície do solo, esbranquiçado, do qual brotam raízes fibrosas, menores, laterais, simples, fasciculadas. Na porção terminal do rizóforo forma-se, a cada ano, uma tuberosidade triangular, lobada, cordiforme ou ovóide-fusiforme, com superfície verrucosa; periderme marrom-acinzentada e medula alva. Lianas, com ramos perenes, esverdeados a amarelados, sinistrogiros, eretos ou apoiantes, sem expansões laterais, $30 \mathrm{~cm}-5 \mathrm{~m}$ compr., tomentosos a pilosos, 0,1-0,6cm diâm. Caules jovens em seção transversal elíptico-circulares, canaliculados, quando mais velhos elípticos, aplanados, comprimidos, amarelados a castanho-escuros, com sulcos longitudinais. Nos ramos jovens pode apresentar pequenos "bulbilhos" na axila das folhas. Folhas alternas, deltóides, rombóides a ovadas, membranáceas, escabrosas, esverdeadas na face adaxial, purpúreas ou variegadas na face abaxial, com pontuações alvas, brilhantes, 7-9 nervuras salientes, 2,5-20cm compr., pecíolos robustos, canaliculados, achatados a cilíndricos, comprimidos, amarelados a castanho-escuros, 1,5-7,5cm compr. Inflorescências estaminadas racemosas, $6-20 \mathrm{~cm}$ compr., flores solitárias com bráctea pubérula, triangular-acuminada na base, ca. $2 \mathrm{~mm}$ compr.; flores com perianto campanulado, pubérulo, creme, amarelado ou róseo; tépalas internas e externas elíptico-lanceoladas, unidas até $1 / 3$ da sua altura, 3-4mm compr.; estames 6 , inseridos na base do tubo das tépalas junto ao pistilódio; anteras ca. $0,5 \mathrm{~mm}$ compr., introrsas, com pêlos escuros, ovado-oblongas, deiscência longitudinal, filetes longos, cilíndricos; pistilódio colunar, estreitado na base, crasso no ápice, ca. 1,2mm compr., sulcado desde a inserção no disco, estilódios 3, lanceolados, com a base alargada, ca. $1 \mathrm{~mm}$ compr. Inflorescências pistiladas em racemos ou espigas, pêndulas, 9-30cm compr.; flores isoladas, com pedicelo curto; perianto campanulado, creme, amarelado a alaranjado-escuro, pilosas, com bráctea lanceo-lada, tomentosa na base, ca. $2 \mathrm{~mm}$ compr. Tépalas internas e externas oblongo-lanceoladas, 1,5-2,1 mm compr., unidas até 1/3 da sua altura; gineceu tricarpelar, colunar, estiletes unidos na base, livres no ápice, ramos bífidos, lanceolados; estaminódios 6, amarelados a alaranjados, oblongo-ovados, filetes com ca. $1 \mathrm{~mm}$ compr.; inseridos na base do estilete. Cápsulas 1,5-2cm compr., 3,5-4cm larg., transversalmente oblongas, pediceladas, glabras, com restos do perigônio no ápice, esverdeadas, amareladas, oliváceas quando secas, brilhantes, com as margens levemente dilatadas. Sementes ca. $4 \mathrm{~mm}$ compr., centrais, elíptico-ovadas, castanho-escuras, com ala circular rugosa, amarelo-alaranjada.

Material examinado: Bahia: Pedra Santa [oeste do estado], V.1913, Lutzelburg 100, fl. masc. (M); São Bento das Lages, 1913, Lutzelburg 120, fl. masc. (M); Cruz das Almas, Instituto Agronômico do Leste, V.1953, G. Pinto s.n., fl. masc. (ALCB); Cruz das Almas, VI.1953, G. Pinto 5346, fl. fem. (ALCB); Cocos, 14.III.1972, W. Anderson et al. 36941, fl. masc. (UB). $15 \mathrm{~km}$ a sudoeste de Maracás, Rodovia BA-026, 5.V.1979, S. Mori E T. Santos 11802 (K, CEPEC); Cachoeira, Pedra do Cavalo, IX.1980, L. Scardino et al. 654, fl. fem., fr. (ALCB, RB), Itapebi, rio Jequitinhonha, 19.VII.1986, G. Pedralli $\mathcal{E}^{\circ}$ Silva 2640 (CEN); HRB); Bom Jesus da Lapa, Joá, 4.IV.1992, C. Xifreda s.n., fl. masc. (MBM, K); Feira de Santana, Lamarão do Passé, 5.X.1994, M. Guedes s.n., fl. masc. (ALCB); Pau Brasil, Mundo Novo, 12.VIII.1995, C.S. Florêncio 012 (ALCB, UESC); Simões Filho, Estação Ecológica Cotegipe, 30.X.1995, M. Guedes et al 3753 (ALCB); sem local, sem data, Blanchet 1560, fl. masc. (P); sem local, sem data, Salzmann s.n., fl. masc. (K); sem local, sem data, Salzmann s.n., fl. fem. (K). Minas Gerais: Belo Horizonte, Jardim Botânico, 11.IV.1934, H. Mello Barreto 2409, fl. masc. (R); Ouro Preto, Área de Proteção Ambiental da Cachoeira das Andorinhas, 21.IX. 1993, G. Pedralli 3408 (HXBH); Turmalina, 17.II.1993, G. Pedralli 3388 , fr. (HXBH); Várzea da Palma, sul da Serra do 


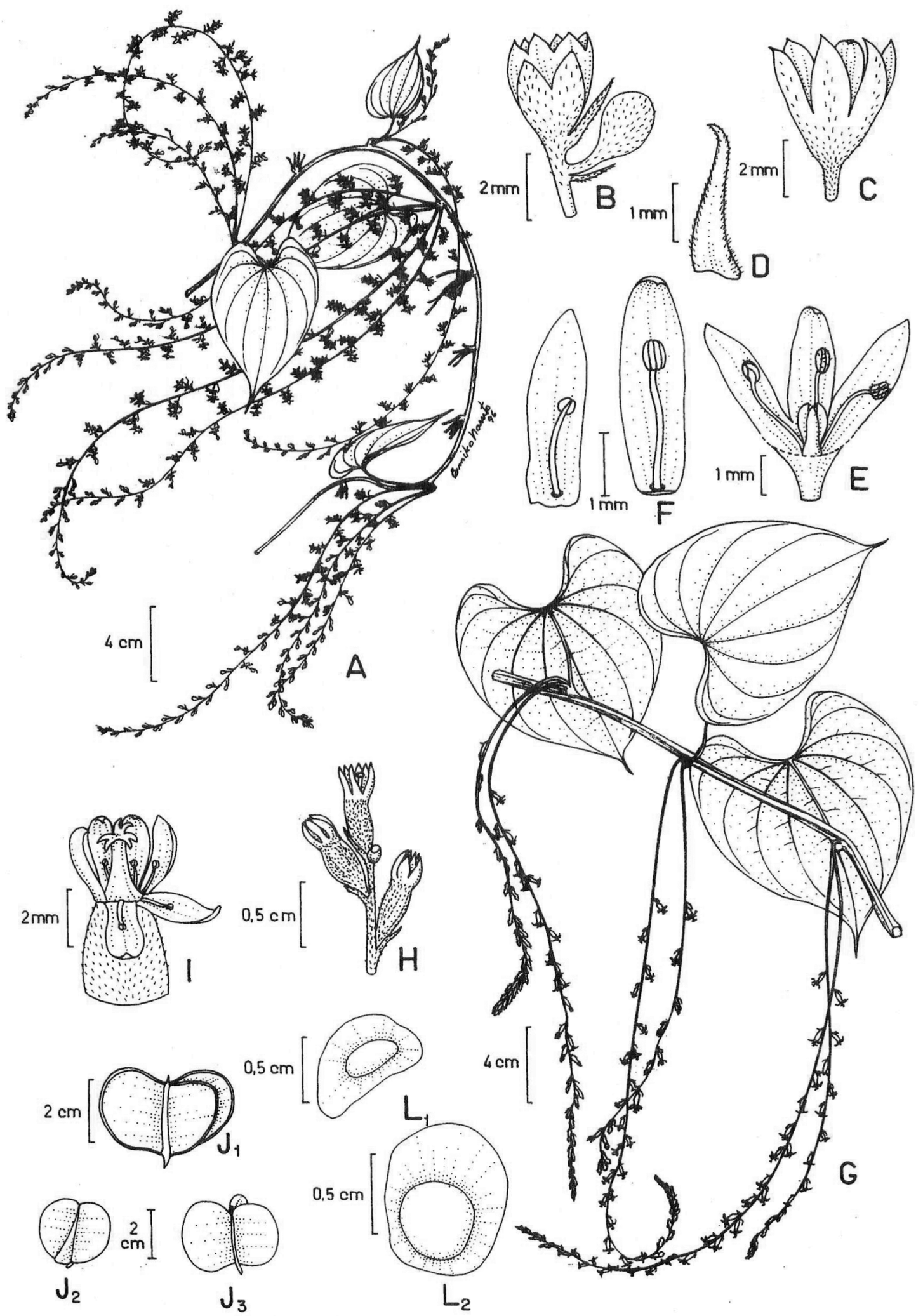

Fig. 9: Dioscorea dodecaneura Vell. A. ramo florífero (planta masculina); B-F. flor estaminada; B. flores jovens; C. flor em antese; D. bráctea pilosa; E. tépalas, estames e pistilódio; F. tépalas e estames; G. ramo florífero (planta feminina); H-I. flor pistilada; H. flores em antese e brácteas; I. perigônio, estaminódios, estilete e estigma; J1-J3. cápsulas; L1-L2. sementes. (A-F: Pedralli Ẽ Teixeira 3429; G-I: Pinto 5346; J1-L2: Pedralli 3388) 
Cabral, 23.XI.1993, G. Pedralli E Teixeira 3421 (HXBH); Ouro Preto, córrego próximo ao Hotel Fazenda das Caieiras, 22.IX.1993, G. Pedralli 3413 (HXBH); km 30 da estrada Várzea da Palma-Jequitaí, 23.XI.1993, G. Pedralli E゚ Teixeira 3425, fl. masc. (HXBH); Jequitaí, 23.XI.1993, G. Pedralli Ẽ Teixeira 3429, fl. masc. (HXBH); Ouro Preto, córrego São Bartolomeu, 21.VI.1994, G. Pedralli E Teixeira s.n. (HXBH); Ouro Preto, sem data, Damazio 1491, fl. masc. (OUPR); Ouro Preto, sem data, Damazio s.n., fl. masc. (RB).

Distribuição geográfica e hábitats: com distribuição pantropical a espécie habita o interior de florestas, em locais sombreados, geralmente úmidos, com solos argiloarenosos, ricos em matéria orgânica, solos aluvionais de florestas galeria ou, ainda, em fendas nos afloramentos rochosos dos campos rupestres da Cadeia do Espinhaço. Ocorre, também, fora do Brasil, no norte da América do Sul, Venezuela e Guiana até na Argentina. Na Amazônia brasileira ocorre em florestas de terra firme, em solos férteis, úmidos. Nos demais estados ocorre no interior de formações florestais, em locais sombreados, úmidos.

Dioscorea dodecaneura apresenta ampla distribuição geográfica ocorrendo nos estados do Acre, Amazonas, Pará, Maranhão, Piauí, Pernambuco, Mato Grosso, Mato Grosso do Sul, Bahia, Espírito Santo, Distrito Federal, Minas Gerais, e do Rio de Janeiro até o Rio Grande do Sul.

9. Dioscorea filiformis Griseb. in Mart. \& Eichl., Fl. bras. 3(1): 44.1842.

Tipo: Brasil, "habitat in silvis prope Tacasava, provinciae S. Pauli", Martius 60, planta masculina (Holótipo $\mathrm{M} !)$.

Dioscorea kunthiana Uline ex R. Knuth, Notizbl. Bot. Gart. Mus. Berlin 7(65): 211. 1917. Tipo: Brasil, Minas Gerais, Serra do Ouro Preto, Schwacke 10381 (Holótipo B!). syn. nov.

Fig. 10

Plantas dióicas. Sistema subterrâneo constituído por um rizóforo longo (ca. $1 \mathrm{~m}$ compr.), profundo, esbranquiçado, axial, levemente engrossado, com pequenas raízes ramificadas marrom-escuras, ou, ainda, com pequenas tuberosidades discóides ao longo do seu eixo, com ca. $1 \mathrm{~cm}$ diâm.; raízes fibrosas contornando a parte basal; periderme marrom e medula alva. Lianas, com ramos perenes, amarelo-esverdeados, sem expansões laterais, sinistrogiras, ou plantas herbáceas, anuais, com ramos amarelados a castanho-escuros, glabros, $15 \mathrm{~cm} \mathrm{a}$ $1 \mathrm{~m}$ compr., ca. $1 \mathrm{~mm}$ diâm. Caules jovens filiformes, com córtex bem desenvolvido, em seção transversal circulares, quando mais velhos elípticos, aplanados; epiderme espessada e cutícula com ornamentação do tipo papilosa. Folhas alternas, lanceoladas, ovadas ou deltóides, ápice agudo, acuminado, base sagitada, cordada, atenuada ou oblíqua, membranáceas, glabras, rugosas, esverdeadas, 7 nervuras salientes, $2,5-12 \mathrm{~cm}$ compr.; folhas sésseis ou com pecíolos delicados a robustos, canaliculados, retorcidos na base, amarelados a castanho-escuros, $1,5-3 \mathrm{~cm}$ compr. Inflorescências estaminadas racemosas, $2-10 \mathrm{~cm}$ compr.; flores $1-3$ por nó, subsésseis, bráctea oblongo-lanceolada, 0,8-1,5mm compr., amareladas ou castanho-escuras; flores com perianto campanulado, branco-amarelado, com pontuações avermelhadas distribuídas irregularmente; tépalas internas e externas ovado-lanceoladas, 0,8-1,2mm compr.; estames 3 , inseridos na base das tépalas externas, junto ao estilódio; anteras ca. $0,3 \mathrm{~mm}$ compr., introrsas, ovaladas a estreitamente elípticas, deiscência longitudinal, filetes $0,8-1 \mathrm{~mm}$ compr., retos ou encurvados na metade da sua altura, cilíndricos; estaminódios ausentes; pistilódio cônico, com 3 sulcos longitudinais, ca. 0,2 mm compr. Inflorescências pistiladas em espigas, pêndulas, 6-12cm compr.; flores com perianto campanulado, amarelado a castanho-escuro, isoladas em cada nó, sésseis a subsésseis, com bráctea lanceolada, ca. $0,8 \mathrm{~mm}$ compr. Tépalas internas e externas ovado-lanceoladas, 0,9-1,2mm compr.; gineceu tricarpelar, crasso, colunar, estiletes 3 unidos, livres no ápice, ramos simples, escuros na extremidade; estaminódios 3, branco-amarelados, pequenos, capitados, ca. 0,1mm compr. Cápsulas 0,3-1 cm compr., circulares, glabras; valvas amarelo-alaranjadas, com pontuações avermelhadas e restos do perigônio no ápice, margem simples. Sementes circulares, uma por valva, castanho-escuras, com alas rugosas.

Material examinado: Bahia: [Casa de Pedra], 1914, Lutzelburg 37, fl. fem., fr. (M); Rio de Contas, Pico das Almas, 23.I.1974, R.M. Harley 25440, fl. masc. (K, CEPEC); Rio de Contas, Pico das Almas, 17.II.1977, R.M. Harley 19578, p.p., fl. masc. (K, RB, CEPEC); Rio de Contas, Pico das Almas, 17.II.1977, R.M. Harley 19578, p.p., fl. fem., fr. (K, RB, CEPEC); Lençóis, 24.IV.1979, L. Noblick s.n., fl. fem. (ALCB); Rio de Contas, Pico das Almas, 22.VII.1979, S. Mori et al. s. n., fl. fem., fr. (CEPEC); Barra da Estiva, Serra do Sincorá, 24.III.1980, R.M. Harley 20901, fl. masc. (K, RB); Barra da Estiva, noroeste da Serra do Ouro, 24.III.1980, R.M. Harley 20896, fl. masc. (K); $9 \mathrm{~km}$ ao sul de Barra da Estiva, 24.III. 1980, R.M. Harley 20871, fl. masc. (K); Lençóis, Serra do Brejão, 22.V.1980, R.M. Harley 22343, fl. masc. (CEPEC, RB); Lençóis, Serra do Brejão, $14 \mathrm{~km}$ a noroeste da sede, 22.V.1980, R.M. Harley 22344 (UEC); Palmeiras, Pai Inácio, 12.VI.1981, S. Mori $\mathcal{E}^{2}$ B. Boom s.n., fl. fem., fr. (CEPEC); Palmeiras, Pai Inácio, 29.VI.1983, M. Guedes 688, fl. masc. (ALCB, HXBH); Piatã, 14.II.1987, R.M. Harley et al. 24172, fl. masc. (SPF); Abaíra, Campo de Ouro Fino, 24.I.1992, J.R. Pirani et al. 


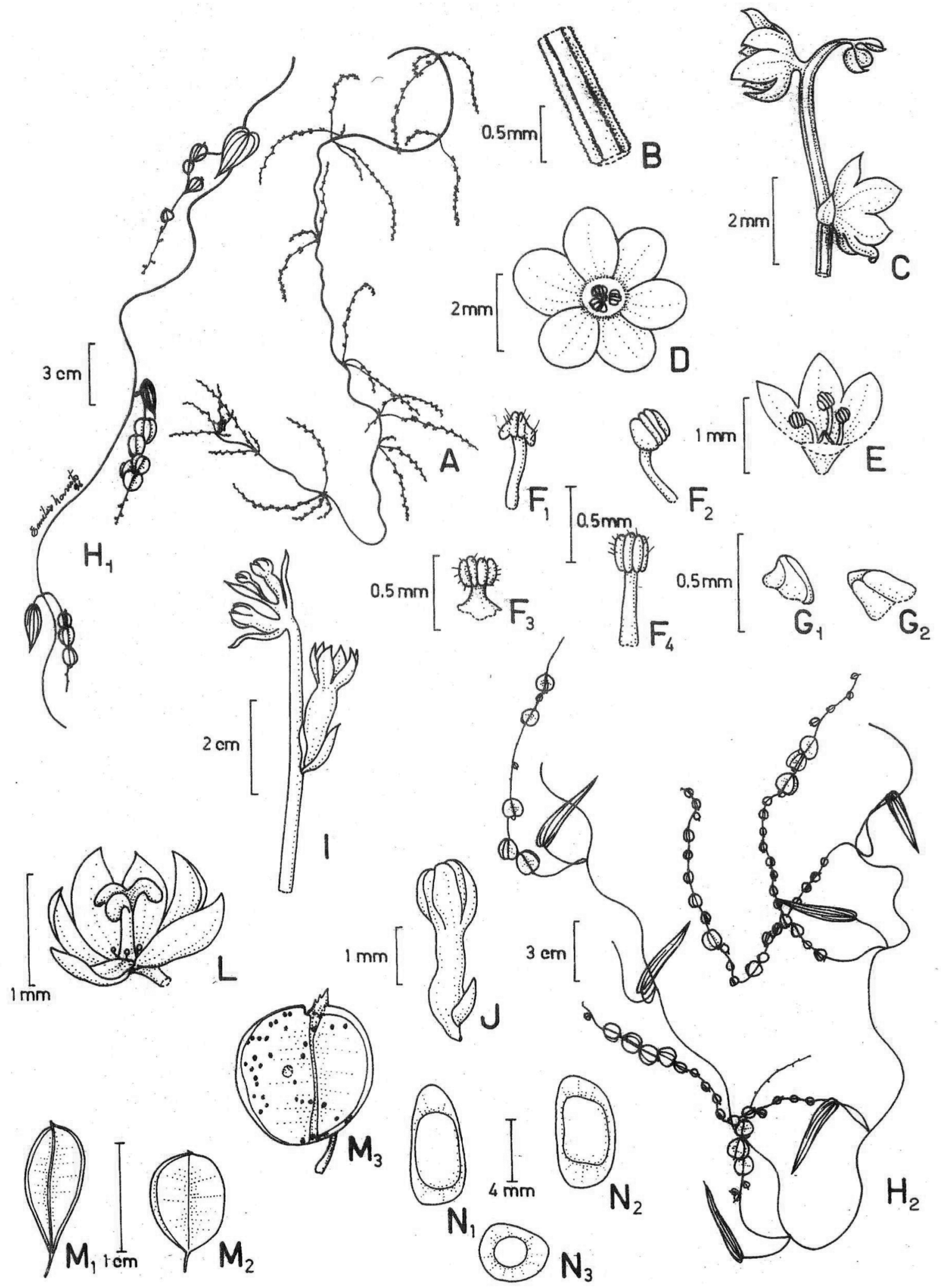

Fig. 10: Dioscorea filiformis Griseb. A. ramo florífero (planta masculina); B. seção do ramo (poligonal) e ornamentação nos ângulos; C-G. flor estaminada; C. flores em antese e bráctea; D. perigônio e estames; E. tépalas, estames e pistilódio; F1-F4. estames; G1-G2. pistilódios; H1H2. ramos floríferos (planta feminina); I-L. flor pistilada; I. flores jovens e em antese, bráctea e profilo; J. flor em antese e bráctea; L. perigônio, estaminódios, estilete e estigma; M1-M3. cápsulas; N1-N3. sementes. (A-G2: Pedralli E๋ Teixeira 3436; H1-L: Pedralli E゚ Teixeira s.n.; M1-N3: Silva E Giulietti 13098) 
50782, fl. masc. (SPF, CEPEC, HUEFS, K); Abaíra, entre Ouro Fino e Pedra Grande, 26.I.1992, E. NicLughadha Ẽ J.R. Pira. ni 51019, fl. masc. (SPF, CEPEC, HUEFS, K); Abaíra, Serra da Água Branca, 7.II.1992, B.L. Stannard E゚ R. Queiroz 51066 , fl. masc. (SPF, K, CEPEC, HUEFS); Abaíra, caminho de Boa Vista-Bicota, 2.III.1992, B.L. Stannard et al. 51713, fl. masc. (SPF, K, CEPEC, HUEFS); Abaíra, Riacho da Taquara, 5.III.1992, T. Laessoe E $\mathcal{F}$ P. Sano 50887, fl. masc. (SPF, K, CEPEC, HUEFS); Abaíra, Garimpo do Bicota, 24.III.1992, B.L. Stannard E T. Silva 52812, fl. masc. (SPF, K, CEPEC, HUEFS); Abaíra, Serra da Tromba, 18.XII.1992, W. Ganev 1684, fl. fem., fr. (HUEFS, SPF); Lençóis, Serra da Chapadinha, 30.VII.1994, R. Orlandi et al. 344, fr. (ALCB). Minas Gerais: Ouro Preto, II.1894, W. Schwacke 10381, fl. masc. (B); [Ouro Preto], Serra de Lavras Novas, II.1894, W. Schwacke 10381, fl. masc. (B); Santana do Riacho, km 128 da estrada Belo Horizonte-Conceição do Mato Dentro, Serra do Cipó, 2.II.1924, H. Mello Barreto s.n., fl. masc. (R); Santana do Riacho, Serra do Cipó, 15.IV.1935, H. Mello Barreto 1003, fl. masc. (BMMH); Santana do Riacho, Serra do Cipó, 16.IV. 1935, H. Mello Barreto 1004, fl. fem., fr. (BHMH); Nova Lima, Mutuca, 15.IV.1945, L. Williams E $V$. Assis 6656, fl. masc. (R); entre Congonhas e Belo Horizonte, km 386, BR-040, 16.III.1957, E. Pereira E $\mathcal{E}^{2}$. Pabst 2389, p.p., fl. masc. (HB); entre Congonhas e Belo Horizonte, km 386, BR-040, 16.III. 1957, E. Pereira $\mathcal{E}^{2}$ G. Pabst 2389, p.p., fl. fem., fr. (HB); Santana do Riacho, Serra do Cipó, 6.II.1958, E.P. Heringer 6230, fl. masc. (UB); Nova Lima, Serra do Curral, 17.IV.1959, Roth 379a, fl. masc. (CEN, CESJ); Nova Lima, Serra do Curral, 17.IV.1959, Roth 379b, fr. (CEN, CESJ); Itabirito, Pico do Itabirito, 11.II.1968, H.S. Irwin et al. 17860, fl. masc. (UB); Santana do Riacho, Serra do Cipó, km 120, 15.II.1968, H.S. Irwin et al. 20153 , fl. fem., fr. (UB); Serro, $18 \mathrm{~km}$ ao norte da sede, 27.II.1968, H.S. Irwin et al. 20470, fl. masc. (UB); Santana do Riacho, Serra do Cipó, 15.II.1968, H.S. Irwin et al. 20113 (UB); Serro, estrada para Diamantina, 23.II.1968, H.S. Irwin et al. 20698, fl. masc. (UB); Diamantina, $12 \mathrm{~km}$ ao nordeste da sede, 27.I.1969, H.S. Irwin et al. 22711, fl. masc. (UB); $12 \mathrm{~km}$ a nordeste de Diamantina, 28.I.1969, H.S. Irwin et al. 22783, fl. masc. (UB); Diamantina, $15 \mathrm{~km}$ a leste da sede, 18. III.1970, H.S. Irwin et al. 27821, fl. masc. (UB); Diamantina, 19.III.1970, H.S. Irwin et al. 27895, fl. masc. (UB); Diamantina, 20.III.1970, H.S. Irwin et al. 27959, fl. masc. (UB); Diamantina, São João da Chapada, estrada para Campo do Sampaio, 29.III.1970, H.S. Irwin et al. 28585 , fl. masc. (UB); Itabirito, 19.XII.1970, L.Krieger 9654, fl. masc. (CEN, CESJ); Caeté, Serra da Piedade, 14.I.1971, H.S. Irwin et al. 30313, fl. masc. (UB); Caeté, Serra da Piedade, 15.I.1971, H.S. Irwin et al. 30398 (UB); Caeté, Serra da Piedade, 13.I.1971, H.S. Irwin et al. 30249, fl. masc. (UB); Caeté, Serra da Piedade, 15.I.1971, H.S. Irwin et al. 30399a, fl. masc. (UB); Caeté, Serra da Piedade, 15.I.1971, H.S. Irwin et al. 30399b, fl. fem., fr. (UB); Itambé do Mato Dentro, $5 \mathrm{~km}$ do Pico do Itambé, 14.II.1972, W. Anderson et al. 35987 (UB); Santana do Ria- cho, Serra do Cipó, 17.II.1972, W. Anderson et al. 36110, fl. masc. (UB); Ouro Preto, estrada para Lavras Novas, 18. XI.1972, A. Peixoto 80 E Andrade 2563 (R); Ouro Preto, Camarinhas, 9.VIII.1979, J. Badini s.n., fl. masc. (UFOP); Ouro Preto, Fazenda do Manso, 6.VIII.1980, H. Lima el al. 1321, fr. (RB); Santana do Riacho, Serra do Cipó, km 111, 1.III.1981,J.R. Pirani et al. 7086, fl. masc. (SPF, SP, MBM, K, F); Santana do Riacho, Serra do Cipó, 23.III.1982, I. Cordeiro et al. $8174 a$, fl. masc. (SPF); Santana do Riacho, Serra do Cipó, 23.III.1982, I. Cordeiro et al. 8174b, fr. (SPF); Gouveia, estrada para a antena de TV, 9.IV.1982, A. Furlan et al. 3216 (SPF); Gouveia, 9.IV.1982, A. Furlan et al. 3248, fl. masc. (SPF); Gouveia, estrada para o Morro do Camilinho, 9.IV.1982, A. Furlan et al. 3256, fl. fem., fr. (SPF); Santana do Riacho, Serra do Cipó, MG-010, 21.V.1982, Pinto 99 (HRB); km 101, Santana do Riacho, Serra do Cipó, estrada para Conceição do Mato Dentro, 1.IV.1983, N. Menezes Ẽ Silva 401, fl. masc. (VIC); Santana do Riacho, Serra do Cipó, 4.IV.1983, N. Menezes $\mathcal{E}$ Silva 401 (VIC); Moeda, Serra da Moeda, 12.V.1983, M.A. Zurlo E Jorge s.n., fl. masc. (UFOP); Brumadinho, Retiro das Pedras, 24.IV.1983, Carvalho 9794, fl. masc. (BHCB); Monte Boa Vista, Serra da Conceição, 6.III.1983, N. Hensold et al. 2910 (SPF); Santana do Riacho, Serra do Cipó, km 125, 1.II.1985, V. Castro et al. 9396 (SPF, SP, F); Itacambira, 9.I.1986, R. Mello Silva et al. 41249, fl. masc. (SPF); Caeté, Serra da Piedade, 27.II.1986, T. Grandi et al. 7253, fl. masc. (BHCB); Tiradentes, Serra de São José, 22.III.1986, R. Mello Silva et al. 42963, fl. fem., fr. (SPF); Caeté, Serra de Piedade, 18.XII.1986, T. Grandi et al. 8579 (BHCB); Santana do Riacho, Serra do Cipó, 1.II.1987, Araujo 7702, fl. masc. (GUA); Ouro Preto, Itacolomi, 25.II.1987, T. Grandi et al. 8232, fl. masc. (BHCB); Diamantina, rodovia Guinda-Conselheiro Mata, 16.III.1987, G. Hatschbach et al. 50918, fl. masc. (MBM); Diamantina, estrada para Conselheiro Mata, 17.IV.1987, J. Prado et al. 10587, fl. masc. (SPF); Diamantina, 10.I.1988, $R$. Simão et al. 11809, fl. masc. (SPF, SP); Grão Mogol, 17.V.1988, G. Hatschbach $\mathcal{E}^{2}$ Ribas 52114 , fl. masc. (MBM); Moeda, Serra da Moeda, 19.XII.1989, T. Grandi Eo Porto 16941 (BHCB); Ouro Branco, Serra do Ouro Branco, 12.V.1990, R. MelloSilva et al. 3964, fl. masc. (SPF, CTES); Santa Bárbara, Caraça, Cascatinha, 14.V.1990, M.M. Arbo et al. 4044, fl. masc. (SPF, CTES); Santana do Riacho, Serra do Cipó, 15.V.1990, R. Mello-Silva et al. 4160, fl. fem., fr. (SPF); Grão Mogol, Trilha dos Garimpeiros, 14.VI.1990, G. Hatschbach $\mathcal{E}$ Nicolack 54298 , fl. masc. (MBM); Santana do Riacho, rodovia Belo Horizonte-Conceição do Mato Dentro, km 130, Serra do Cipó, 11.VIII.1990, A. Freire-Fierro E' G. Esteves 1607, fl. masc. (SPF); Santana do Riacho, Córrego das 3 Pontinhas, Serra do Cipó, 23.XI.1990, A. Freire-Fierro $\mathcal{E} \mathcal{O} F$. Pires 1555, fl. fem., fr. (SPF, QCA); 7km a nordeste de Cardeal Mota, 8.II.1991, M.M. Arbo et al. 4603, fl. masc. (SPF, CTES); Santana do Riacho, Serra do Cipó, 1.III.1991, J.R. Pirani et al. 7085 (SPF, SP, MBM); Santana do Riacho, Serra do Cipó, 20.III.1991, J.R. Pirani et al. 12068 (SPF); Santana do Riacho, Serra da 
Lapinha, 27.III.1991, J.R. Pirani et al. 12139, fl. masc. (SPF); Santana do Riacho, Serra do Cipó, Juquinha, 4.IV.1992, $G$. Pedralli s.n. (HXBH); Santana do Riacho, Serra do Cipó, 4.IV.1992, G. Pedralli s.n. (HXBH); Santana do Riacho, 2.VI.1991, R. Simão-Bianchini E Bianchini 12801, fl. masc. (SPF); Santana do Riacho, Parque Nacional da Serra do Cipó, 27.VI.1991, E. Pereira et al. 734 (BHCB); Santana do Riacho, Serra do Cipó, km 125 da estrada Belo Horizonte-Conceição do Mato Dentro, 29.VI.1991, J.R. Pirani et al. 12370a, fl. masc. (SPF); Santana do Riacho, Serra do Cipó, km 125 da estrada Belo Horizonte-Conceição do Mato Dentro, 29.VI. 1991, J.R. Pirani et al. 12370b, fl. fem., fr. (SPF); Santana do Riacho, Serra do Cipó, Alto do Palácio, 3.IV.1992, G. Pedralli s.n., fl. masc. (HXBH); Santana do Riacho, Serra do Cipó, Juquinha, 4.IV.1992, G. Pedralli s.n., fl. masc. (HXBH); Santana do Riacho, Serra do Cipó, Córrego das Duas Pontinhas, 5.IV.1992, G. Pedralli s.n., fl. masc. (HXBH); Santana do Riacho, Serra do Cipó, Alto do Palácio, 13.V.1992, G. Pedralli s.n., fl. masc. (HXBH); Santana do Riacho, Parque Nacional da Serra do Cipó, Alto do Palácio, 1.V.1993, J.R. Pirani $\mathcal{E}^{2}$ A. Giulietti 13040, p.p., fl. masc. (SPF); Santana do Riacho, Parque Nacional da Serra do Cipó, Alto do Palácio, 1.V.1993, J.R. Pirani $\mathcal{E}$ A.M. Giulietti 13040, p.p., fr. (SPF); Santana do Riacho, Serra do Cipó, 2.V.1993, T. Silva $\mathcal{E}$ A. Giulietti 13098, fr. (SPF); Santana do Riacho, Serra do Cipó, 3.VII.1993, G. Pedralli E Teixeira s.n., fl. masc. (HXBH); Santana do Riacho, Serra do Cipó, 3.VII.1993, G. Pedralli E Teixeira s.n., fl. fem., fr. (HXBH); Ouro Preto, Parque Estadual do Itacolomi, 15.XII.1993, Teixeira E Oliveira s.n. (HXBH); Caeté, Serra da Piedade, 21.X.1993, G. Pedralli E Teixeira 3420, fl. masc. (HXBH); Santa Bárbara, Parque Natural do Caraça, próximo à gruta, 27.X.1993, G. Pedralli 3416 Ev Teixeira, fl. masc. (HXBH); Santa Bárbara, Parque Natural do Caraça, em floresta mesófila, 27.X.1993, G. Pedralli $3414 \mathcal{E}$ Teixeira, fl. masc. (HXBH); Serra do Cabral, Joaquim Felício, 24.XI.1993, G. Pedralli $\mathcal{E}$ Teixeira 3436, fl. masc. (HXBH); Ouro Preto, Parque Estadual do Itacolomi, 15.XII. 1993, Teixeira E Oliveira s.n. (HXBH): Ouro Preto, Parque Estadual do Itacolomi, trilha para a antena de TV, 15.XII. 1993, Oliveira EO Teixeira s.n. (HXBH); Ouro Preto, Parque Estadual do Itacolomi, campo rupestre próximo à antena de TV, 15.XII.1993, Teixeira E Oliveira s.n. (HXBH); Joaquim Felício, Serra do Cabral, 24.XI.1993, G. Pedralli E Teixeira 3436 (HXBH); Caeté, alto da Serra da Piedade, 29.X.1993, G. Pedralli $\mathcal{E}$ Teixeira 3420 (HXBH); Ouro Preto, Parque Estadual do Itacolomi, caminho ecológico, 15.XII.1993, Olivei$r a \in \mathcal{E}$ Teixeira s.n. (HXBH); Ouro Preto, Parque Estadual do Itacolomi, 15.XII.1993, Teixeira E Oliveira s.n. (HXBH); Ouro Preto, APA da Cachoeira das Andorinhas, 10.XI.1993, Teixeira EF Oliveira s.n. (HXBH); Santa Bárbara, Parque Natural do Caraça, caminho da gruta, 27.X.1993, G. Pedralli Ẽ Teixeira 3414 (HXBH); Itabirito, Pico do Itabirito, 16.III.1994, A. Teixeira s.n., fl. masc. (BHCB, HXBH); Ouro Preto, caminho para Pico Itacolomi, 21.VI.1994, G. Pedralli E Teixeira s.n. (HXBH); Santana do Riacho, Serra do Cipó, córrego das Duas Pontinhas, 22.II.1995, G. Pedralli E Teixeira s.n., fl. masc. (HXBH); Santana do Riacho, Serra do Cipó, 6.IV.1995, J. Lombardi 719, fl. masc. (BHCB, HXBH); Ouro Preto, Serra de Ouro Preto, sem data, Damazio 1483, fl. masc. (OUPR); Diamantina, sem data, Schwacke 8421, fl. masc. (B).

Distribuição geográfica e hábitats: com distribuição neotropical e restrita à América do Sul, na Cadeia do Espinhaço as populações de $D$. filiformis são encontradas em afloramentos rochosos nos campos rupestres e na borda de florestas de galeria, em locais bem drenados, sombreados, com solos férteis.

Dioscorea filiformis distribui-se desde a Bahia até o Paraná na Floresta Atlântica, em Goiás e Tocantins incluindo o Distrito Federal, nos campos rupestres e florestas de galeria.

Rocha \& Menezes (1997) estudaram o sistema subterrâneo dessa espécie, referindo-a como Dioscorea kunthiana Uline ex R. Knuth, baseadas em material da serra do Cipó, Minas Gerais. Porém, aqui se considera $D$. kunthiana como sinônimo de $D$. filiformis, pois a descrição original concorda perfeitamente e a análise do holótipo do binômio proposto por Knuth (1917) correspondente a um ramo de planta estaminada e também de planta pistilada (v. Pedralli 1998).

10. Dioscorea hassleriana Chodat in Chodat \& Hassler, Bull. Herb. Boiss. 3(2): 1111, 1903. Tipo: "Paraguay, in vale fluminis Y-acá prope Chololó”, XII.1900, Hassler 6853, planta masculina (Holótipo G!; Isótipos BM!, K!). Fig. 11

Plantas dióicas. Sistema subterrâneo constituído por um rizóforo alongado (ca. $10 \mathrm{~cm}$ compr.), profundo, tuberosidade lenhosa, única, irregular; comprimida lateralmente, com a base alargada, lobada e raízes grossas, curtas, brotando da porção inferior; periderme alaranjado-escura a marrom e medula branco-amarelada. Lianas com ramos perenes, avermelhados (os jovens), amarelados, alaranjados a marrom-escuros, sem expansões laterais, dextrogiros, eretos, apoiantes ou volúveis, 0,5$3 \mathrm{~m}$ compr., glabros ou papilosos (os mais jovens), com pequenas pontuações escuras, 1-5mm diâm. Caules jovens em seção transversal circular-elípticos, quando mais velhos circulares, aplanados, canaliculados, robustos na base, filiformes no ápice dos ramos. Folhas alternas, as da base triangulares a hastado-trilobadas, as do ápice sagitado-cordadas, acuminadas, agudas ou truncadas, cartáceas, glabras a velutinas na face abaxial, esverdeadas a oliváceas, com 7-9 nervuras salientes em ambas as faces, $2,5-11 \mathrm{~cm}$ compr., com pontuação avermelhada no limbo, densa e reticulada; pecíolos robustos, retorcidos na inserção no caule, amarelo-alaranjados, gla- 


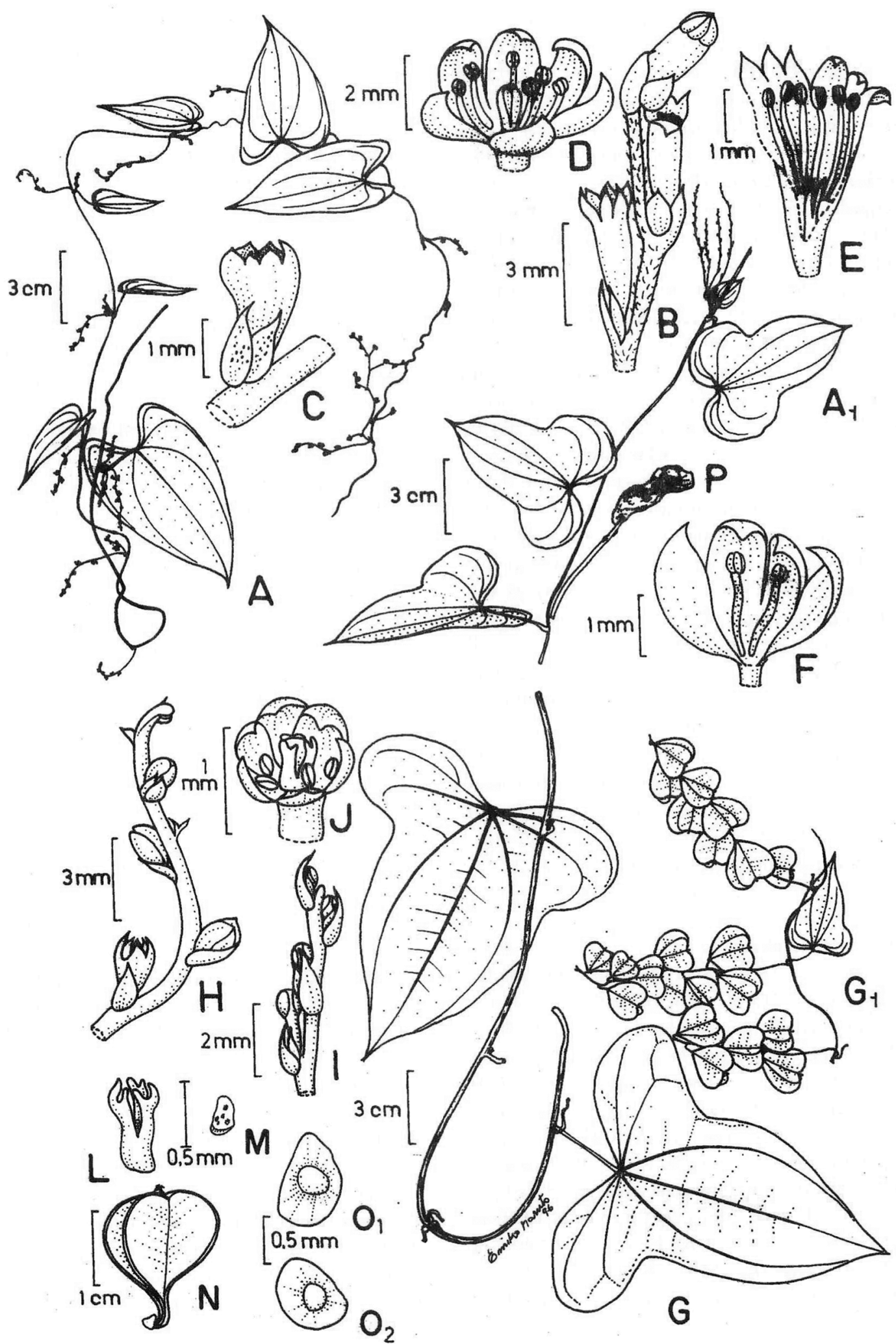

Fig. 11: Dioscorea hassleriana Chodat. A-A1. ramos floríferos (planta masculina); B-F. flor estaminada; B. flores em antese, brácteas e profilos; C. flor em antese, bráctea e profilos; D-E. perigônio, estames e pistilódio; F. tépalas e estames; G. ramo e folhas (planta feminina); G1. ramo florífero (planta feminina); H-M. flor pistilada; H. flores em antese e brácteas e profilos; I. flores jovens, brácteas e profilos; J. perigônio, estaminódios e estiletes; L. estiletes; M. estaminódio; N. cápsula; O1-O2. sementes; P. rizóforo e tuberosidade lenhosa. (A-F: Pedralli 380; G-O2: Gehrt s.n.; P: Pedralli 3415 Ẽ Teixeira) 
bros, canaliculados, $0,5-3 \mathrm{~cm}$ compr. Inflorescências estaminadas em espigas simples ou ramificadas, eretas ou pêndulas, $3-8 \mathrm{~cm}$ compr., flores isoladas em cada nó floral; bráctea oblongo-acuminada ou oblongo-aristada, ca. $2 \mathrm{~mm}$ compr., profilo elíptico-acuminado, ca. 1,2 mm compr., ambos com pontuações avermelhadas; flores com perianto campanulado, amarelado, esverdeado ou alaranjado; tépalas internas e externas oblongoagudas, reflexas para o exterior, 1,8-2,2mm compr.; estames 6 , exsertos na antese, inseridos na base de cada tépala, subiguais; anteras ca. $0,3 \mathrm{~mm}$ compr., introrsas, elípticas, deiscência longitudinal, filetes $1,2-2 \mathrm{~mm}$ compr., planos, comprimidos, coalescentes ao tubo até a metade da sua altura; pistilódio cilíndrico, ca. $1,1 \mathrm{~mm}$ compr., trífido a partir de $1 / 3$ da sua altura, estilódios 3 , linear-agudos, ca. $0,7 \mathrm{~mm}$ compr., hialinos a alaranjado-claros. Inflorescências pistiladas em espigas, pêndulas, $4-12 \mathrm{~cm}$ compr.; flores com perianto urceolado, amarelado, esverdeado a alaranjado, isoladas em cada nó floral, pedunculadas; bráctea ca. $1,8 \mathrm{~mm}$ compr., profilo ca. $1 \mathrm{~mm}$ compr., oval-acuminados ou oval-aristados; tépalas internas e externas oblongo-elípticas, 0,6$1 \mathrm{~mm}$ compr., reflexas para o exterior na entese; gineceu tricarpelar, colunar, estiletes soldados na base, livres a partir de $2 / 3$ da sua altura, ramos bífidos, reflexos para o interior; estaminódios 6 , branco-amarelados, sésseis, elípticos, ca. 0,2mm compr. Cápsulas 1-2,2 compr., obovadas a largamente obovadas, valvas amareladas, alaranjadas, esverdeadas a violáceas, truncadas, com restos do perigônio no ápice, margens levemente dilatadas, pedicelo retorcido. Sementes $7-10 \mathrm{~mm}$ compr., circulares a ovais, marrom-escuras, rugosas, membranáceas, com ala circular reticulada.

Material examinado: Bahia: a 5km de Catolés, 24.XI.1992, W. Ganev 1548, fl. masc. (HUEFS, SPF); Abaíra, Tanquinho, 14.XII.1992, W. Ganev 1445, fl. masc. (HUEFS, SPF); Mucujê, próximo à entrada da cidade, 22.II.1993, G. Pedralli 3397, fl. masc. (HXBH); Lençóis, Serra da Chapadinha, próximo ao riacho Mucugezinho, 5.VII.1994, A. Giulietti et al 023., fl. masc. (SPF, K, ALCB). Minas Gerais: Belo Horizonte, IV.1898, A. Silveira 2733, fl. masc. (R); Belo Horizonte, Gameleira, 23.II.1919, A. Gehrt s.n., fl. fem., fr. (SP); $7 \mathrm{~km}$ a oeste de Grão Mogol, 16.II.1969, H.S. Irwin et al. 23385, fl. fem., fr. (UB); Santana do Riacho, Serra do Cipó, 17.II.1972, W. Anderson et al. 36075, fl. masc. (UB); Diamantina, Serra do Espinhaço, 16.II.1973, G. Hatschbach E A Ahumada 31632, fl. masc. (MBM); Grão Mogol, subida para o Pasto, 17.V.1988, G. Hatschbach $\mathcal{E}$ Ribas 52109, fr. (MBM); Grão Mogol, vale do rio Itacambiruçu, 12.XII.1989, J.R. Pirani et al. 12572, fl. masc. (SPF, SP); Conceição do Mato Dentro, margem direita do rio Santo Antônio, 14.VI.1992, G. Pedralli 380, fl. masc. (HXBH); Grão Mogol, 19.II.1993, G. Pedralli 3393, fl. masc. (HXBH); Santa Bárbara, Parque Natural do Caraça, cami- nho para a igrejinha, 27.X.1993, G. Pedralli 3415 E Teixeira, fl. masc. (HXBH); a $11 \mathrm{~km}$ de Joaquim Felício, Serra do Cabral, 24.XI.1993, G. Pedralli $§$ Teixeira 3435, fl. masc. (HXBH); Joaquim Felício, Serra do Cabral, 24.XI.1993, $G$. Pedralli E' Teixeira 3431, fl. masc. (HXBH); Belo Horizonte, sem data, L. Krieger s.n (CESJ, CEN); Ouro Preto, sem data, J. Badini 237 (OUPR).

Distribuição geográfica e hábitats: a espécie apresenta distribuição neotropical e exclusiva da América do Sul, e na Cadeia do Espinhaço ocorre nos campos rupestres, em solos arenosos ou pedregosos, bem drenados e de baixa fertilidade ou, em fendas nos afloramentos rochosos, onde exista uma camada mínima de solo.

Dioscorea hassleriana distribui-se pelos estados do Mato Grosso, Goiás, Distrito Federal, Minas Gerais e da Bahia até o Rio Grande do Sul, habitando a borda de florestas estacionais (mesófilas), o interior de florestas de galeria e da Floresta Atlântica, os cerrados típicos e áreas abertas dos campos rupestres. Ocorre, ainda, nas Guianas e Argentina (províncias de Jujuy e Salta).

11. Dioscorea heptaneura Vell., Fl. flum. 10 (ícones): tab. 124. 1831, et in Archos. Mus. Nac. Rio de Janeiro 5: 426. 1881.

Tipo: Vellozo, Fl. flum. 10 (ícones): tab. 124. 1831 (Lectótipo).

Fig. 12

Plantas dióicas. Lianas com ramos perenes, esverdeados, amarelados, alaranjados a castanho-escuros, sem expansões laterais, sinistrogiros, apoiantes em ervas e arbustos, 0,2-1 m compr., glabros, com pontuações avermelhadas desde a base até a metade da sua altura, ca. $0,1 \mathrm{~mm}$ diâm. Caules jovens em seção transversal transversalmente elípticos, comprimidos, canaliculados, quando mais velhos pentagonais a circulares, canaliculados. Folhas alternas, oblongo-lanceoladas, acuminadas, atenuadas em direção ao ápice, cartáceas, glabras, esverdeadas, castanho a castanho-escuras, com pontuações avermelhado-escuras densa e miudamente distribuídas em ambas as faces, 2,5-7cm compr.; pecíolos curtos, robustos, retorcidos na sua inserção nos ramos, canaliculados, glabros, 2-10mm compr. Inflorescências estaminadas em espigas, 4-12cm compr., bráctea oblongo-acuminada, ca. $2 \mathrm{~mm}$ compr.; profilo com mesma forma, ca. 1,5mm compr., hialino; flores com perianto campanulado, esverdeadas, amareladas a alaranjadoescuras; tépalas internas e externas oblongo-acuminadas, 1,5-2mm compr.; estames 3, longos, inseridos na soldadura das tépalas; anteras ca. $0,3 \mathrm{~mm}$ compr., lateral-introrsas, oblongas a elípticas, deiscência longitudinal, filetes 1-1,2mm compr., grossos, cilíndricos; pistilódio grosso, cilíndrico na base, tripartido a partir da 


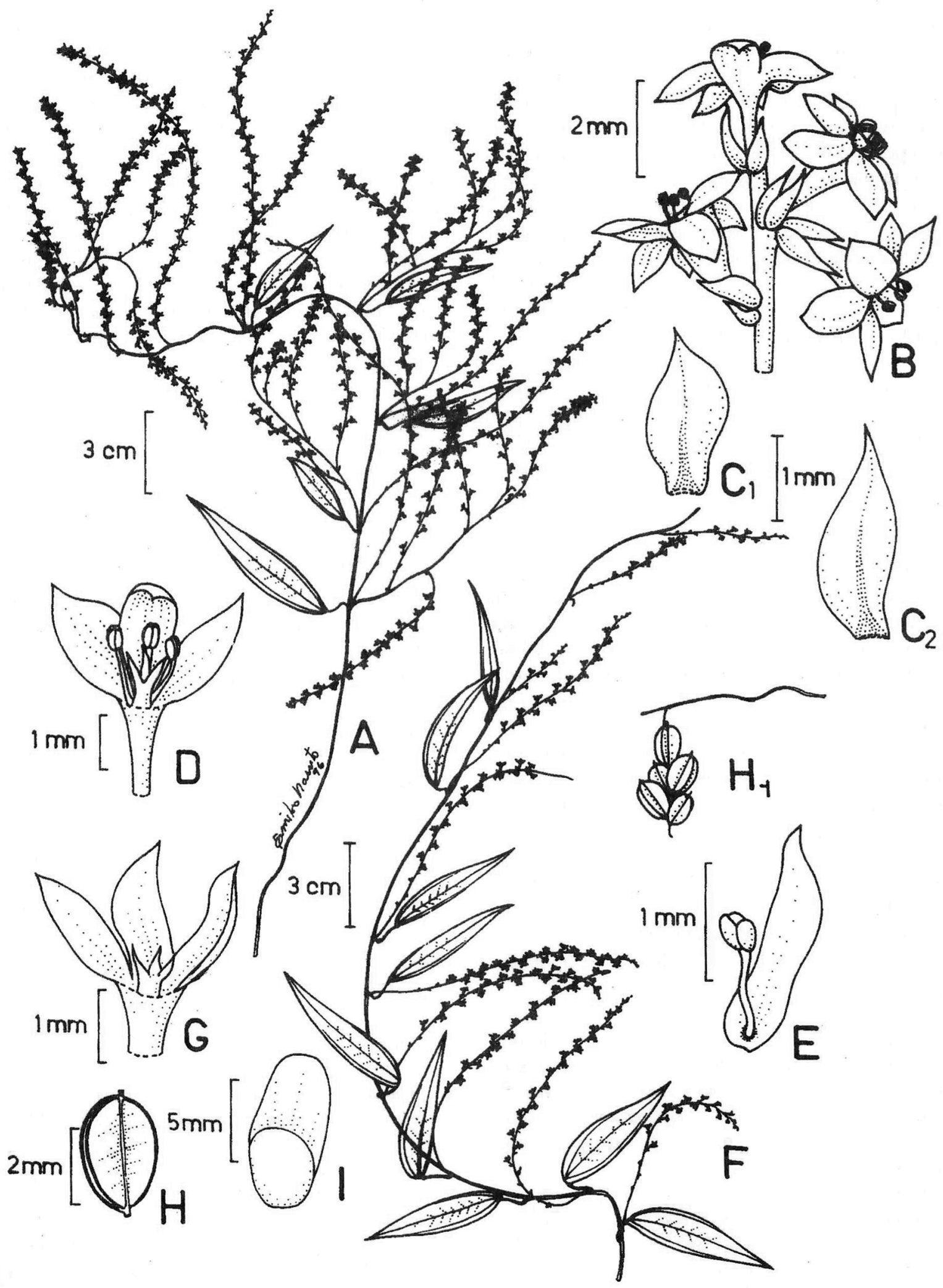

Fig. 12: Dioscorea heptaneura Vell. A. ramo florífero (planta masculina); B-E. flor estaminada; B. flores em antese, brácteas e profilos; C1. bráctea; C2. profilo; D. tépalas, estames e pistilódio; E. tépala e estame; F. ramo florífero (planta feminina); G. flor pistilada, tépalas e estiletes; H. cápsula; I. semente. (A-E: Assump̧̧ão 1628A; F-I: Assumpção 1628B) 
metade da sua altura, ca. $1 \mathrm{~mm}$ compr., estilódios linear-lanceolados, ca. $0,5 \mathrm{~mm}$ compr. Inflorescências pistiladas em racemos, $3-10 \mathrm{~cm}$ compr., bráctea e profilo oblongo-acuminados, glabras, $1,5-2,1 \mathrm{~mm}$ compr.; perianto campanulado, esverdeado; tépalas internas e externas oblongo-acuminadas, 1,8-2,1mm compr.; gineceu tricarpelar, colunar, estiletes soldados na base, ca. $1 \mathrm{~mm}$ compr., branco-amarelado, livres no ápice, ramos bífidos, alaranjado-escuros. Cápsulas $2,8-3,1 \mathrm{~cm}$ compr., elípticas, valvas branco-amareladas, apiculadas, com as margens levemente dilatadas, com restos do perigônio persistentes até a sua maturação. Sementes ca. 1 cm compr., ovais a circulares, escuras, rugosas, com asa prolongada em direção ao ápice.

Material examinado: Minas Gerais: Diamantina, Capões, estrada para Biribiri, 26.III.1892, Schwacke 8419, fl. masc. (B); Ouro Preto, Lavras Novas, 1936, G. Assump̧̧ão 1628A, fl. masc. (OUPR); Ouro Preto, Lavras Novas, 1936, G. Assunção 1628B, fl. fem., fr. (EM); Ouro Preto, Lavras Novas, 1936, G. Assumpção 1756, fl. masc. (OUPR).

Distribuição geográfica e hábitats: D. heptaneura apresenta distribuição neotropical e exclusiva no Brasil. Ocorre em terrenos úmidos, em fendas de rochas ou em solos pedregosos nos campos rupestres de Minas Gerais e nos campos de altitude do Rio de Janeiro. Existe uma única coleta de Mosén 3501 do litoral de São Paulo, em área de restinga.

Não foi possível coletar material da espécie e os materiais herborizados estudados não apresentavam sistema subterrâneo, razão pela qual sua descrição não está contemplada no texto.

12. Dioscorea laxiflora Griseb. in Mart. \& Eichl., Fl. bras. 3(1): 32. 1842.

Tipo: Brasil, "in silvis prov. Bahia prope Ilheos et Almada", I.1819, Martius 69, planta masculina (Lectótipo, M!). Fig. 13

Plantas dióicas. Sistema subterrâneo constituído por rizóforo subsuperficial ou enterrado profundamente, com tuberosidades distribuídas ao longo do seu eixo, inteiras ou lobadas, alongadas, triangulares, arredondadas ou aplanadas, com a porção basal alargada e superfície estriada e rugosa; periderme acinzentada e medula branco-amarelada. Das tuberosidades brotam raízes albescentes, filiformes, formando um verdadeiro emaranhado. Lianas com ramos perenes, esverdeados a castanho-escuros, sem expansões laterais, dextrogiros, 1-5m compr., glabros, 1-3mm diâm. Caules jovens em seção transversal circulares a poligonais, estriados longitudinalmente, quando mais velhos aplanados, elípticos, canaliculados, retorcidos na base, com pequenos pontos avermelhados distribuídos irregularmente na superfície. Folhas simples, alternas, triangulares a ovais, cartáceas a membranáceas, glabras, acuminadas, cordadas a hastadas, lobos basais divergentes, 'sinus' com largura variável, esverdeadas, amareladas a castanhoescuras, com 5-7 nervuras salientes na face abaxial, 2$15 \mathrm{~cm}$ compr.; pecíolos robustos, canaliculados, esverdeados, glabros, $0,5-4 \mathrm{~cm}$ compr. Inf lorescências estaminadas racemosas, $4-12 \mathrm{~cm}$ compr., flores com perianto campanulado, amareladas, esverdeadas ou violáceas, isoladas em cada nó floral; bráctea e profilo ovado-acuminados, hialinos, esverdeados ou alaranjados, 0,5-3 mm compr.; tépalas internas e externas ovadas a oblongo-lanceoladas, 0,8-1,5mm compr.; estames 6 , com filetes inseridos nas paredes do tubo a $1 / 3$ da base das tépalas; anteras extrorsas, elíptico-oblongas, deiscência longitudinal, filetes $1 \mathrm{~mm}$ compr., filiformes, achatados na base, depois cilíndricos; pistilódio globoso, cônico, amarelado, trissulcado no ápice, ca. $0,8 \mathrm{~mm}$ compr. Inflorescências pistiladas em espigas, pêndulas, $5-25 \mathrm{~cm}$ compr.; flores com perianto campanulado, amarelado, alaranjado a castanho-escuro, isoladas em cada nó floral, sésseis; bráctea e profilo ovado-agudos, ca. $1 \mathrm{~mm}$ compr.; tépalas internas e externas oblongas a ovado-acuminadas, 1-1,5mm compr.; gineceu tricarpelar, colunar, sulcado desde a base, tripartido no ápice, ramos bífidos, grossos; estaminódios 6 , amarelados, pedicelados, rudimentos de anteras oblongos, branco-amare-lados, ca. $0,3 \mathrm{~mm}$ compr. Cápsulas 1,5-2,5cm compr., pediceladas, obovadas ou transversalmente oblongas, valvas esverdeadas (ao vivo), amareladas, alaranjadas a castanho-escuras em material seco, escuras no centro, membranáceas, margens simples. Sementes 1-1,5cm compr., centrais, circulares, marrom-escuras, rugosas, com asa circular.

Material examinado: Bahia: Abaíra, final da subida do brejo, IX.1992, W. Ganev s.n., fl. fem., fr. (HUEFS, SPF). Minas Gerais: Belo Horizonte, Jardim Botânico, 11.III.1934, Sampaio 7297 , fl. masc. (R); Diamantina, $3 \mathrm{~km}$ ao norte de São João da Chapada, 24.III.1970, H.S. Irwin et al. 28263, fl. masc. (UB); Barão de Cocais, Serra do Caraça, 22.I.1971, H.S. Irwin et al. 28892, fl. masc. (UB); Conceição do Mato Dentro, rio Santo Antônio, 28.IV.1978, G. Martinelli 4403, fr. (RB); Conceição do Mato Dentro, rio Santo Antônio, 19.IV.1981, L. Rossi Ẽ M.C. Amaral 7261, fl. masc. (SPF, SP, K, F); oeste de Santana do Pirapama, Serra do Cipó, 20.III.1982, J.R. Pirani et al. 7906, fl. masc. (SPF, SP); ); Santo Antônio do Itambé, Serra do Gavião, 3.IV.1982, A. Furlan et al. 2991, fl. fem. (SPF); estrada para Cardeal Mota, rio Santo Antônio, 17. V.1990, M.M. Arbo et al. 4292, fl. fem. (CTES, SPF); Grão Mogol, saída para Cristália, 19.II.1993, G. Pedralli 3392, fl. masc. (HXBH); Belo Horizonte, campus da UFMG, Estação Ecológica, 17.XII.1994, J. Lombardi 670, छ L. Temponi, fr. (BHCB, HXBH). 


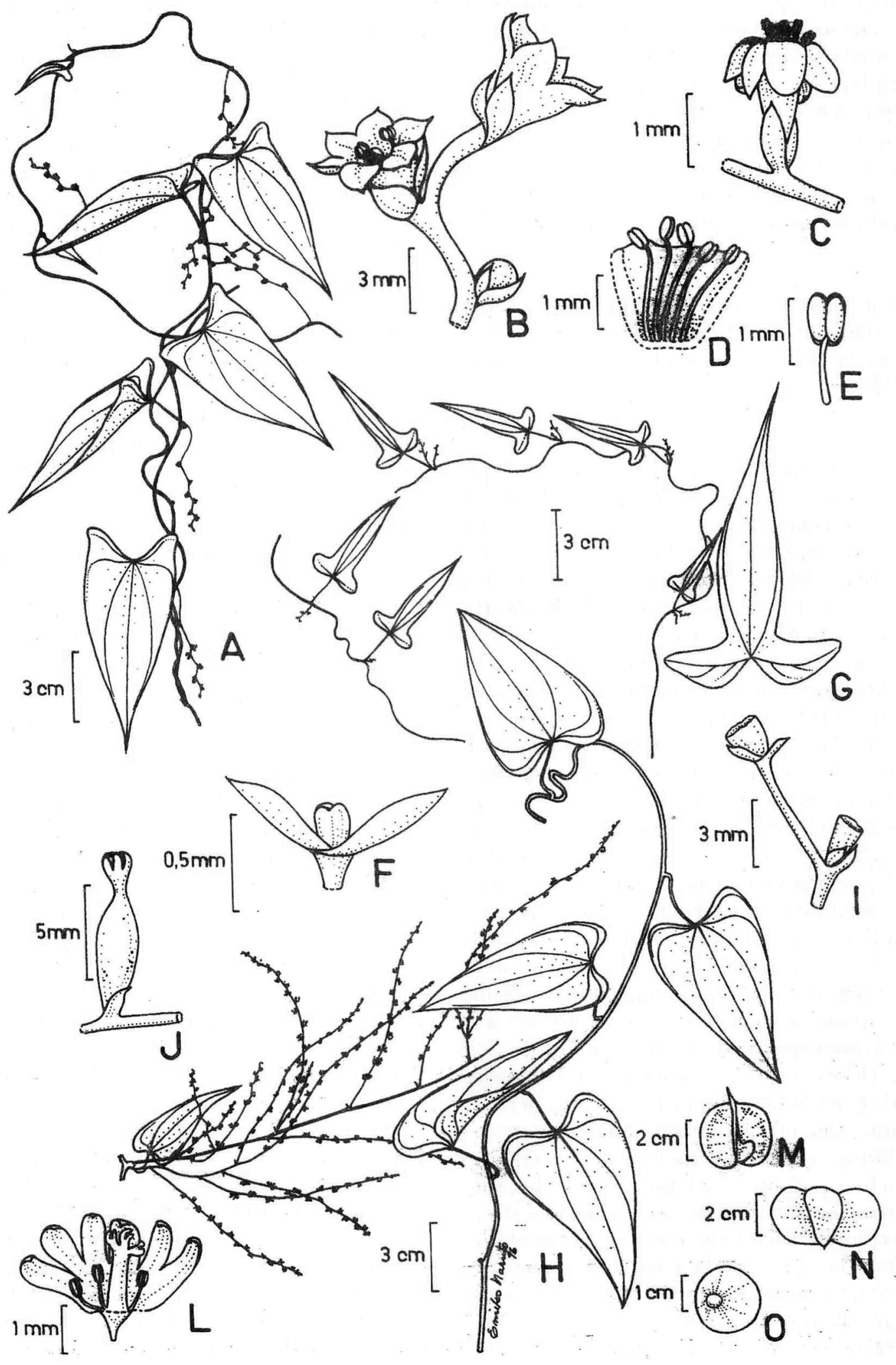

Fig. 13: Dioscorea laxiflora Griseb. A. ramo florífero (planta masculina); B-F. flor estaminada; B. flores em antese, brácteas e profilos; C. flor em antese, bráctea e profilo; D. tépalas e estames; E. estame; F. tépalas e pistilódio; G-H. ramos floríferos (planta feminina); I-L. flor pistilada; I. flores jovens, brácteas e profilos; J. flor em antese e bráctea; L. perigônio, estaminódios, estilete e estigmas; M-N. cápsulas: O. semente. (A-F: Pedralli 3392; G-L: Arbo et al. 4292; M-O: Lombardi Ẽ Temponi 670) 
Distribuição geográfica e hábitats: a espécie apresenta distribuição neotropical e exclusiva do Brasil, e na Cadeia do Espinhaço ocorre na orla de florestas estacionais (mesófilas), em capões de mata, nas fendas dos afloramentos rochosos, em florestas de galeria e na orla de florestas secundárias.

Distribui-se pelos estados do Amazonas, região Nordeste do Brasil, Mato Grosso, Goiás, Distrito Federal, Minas Gerais, Bahia e do Espírito Santo até Santa Catarina.

13. Dioscorea maianthemoides R. Knuth, Notizbl. Bot. Gart. Mus. Berlin 7(65): 188. 1917. Tipo: Brasil, "Staat Goyaz”, Glaziou 22224, planta masculina (Holótipo B!; Isótipos $\mathrm{K}$ ! P!).

Fig. 14

Plantas dióicas. Sistema subterrâneo constituído por um rizóforo axial (ca. $20 \mathrm{~cm}$ compr.), profundo, medula branco-amarelada, esbranquiçado no seu terço inicial, depois marrom-escuro, do qual brotam raízes menores, filiformes, delgadas, esparsas. As plantas podem apresentar pequenas tuberosidades arredondadas (ca. $2 \mathrm{~cm}$ diâm.) ao longo do seu eixo, ou irregulares, comprimidas, achatadas, de onde brotam pequenas raízes escuras, filiformes; periderme marrom-escura e medula branco-amarelada. Plantas herbáceas, volúveis ou apoiantes, anuais, com ramos castanho-escuros, com ramos branco-esverdeados, dextrogiros; sem expansões laterais; quando herbáceas com $5-15 \mathrm{~cm}$ altura. Ramos glabros nas plantas herbáceas; lianas com $30-80 \mathrm{~cm}$ compr., ramos glabros a pilosos; caules jovens em seção transversal triangular-circulares, quando mais velhos circulares, castanho-escuros. Folhas simples, alternas, oblongas a linear-lanceoladas, cordadas, acuminadas, cartáceas, glabras, com 5 nervuras salientes em ambas as faces, $3-11 \mathrm{~cm}$ compr., com pontuações avermelhado-escuras esparsas no limbo; pecíolos muito curtos ou ausentes. Inflorescências estaminadas racemosas, 3-25 cm compr.; flores 1-2 por nó; bráctea e profilo oblongo-apiculados, 1-1,5mm compr.; flores com perianto campanulado, amarelo-alaranjado; tépalas internas e externas oblongo-ovadas, 1-2,2mm compr.; estames 6 , soldados na base próximo à sua inserção no tubo; anteras ca. $0,8 \mathrm{~mm}$ compr., introrsas, ovado-elípticas, curvadas na inserção dos filetes, deiscência longitudinal, filetes ca. $2 \mathrm{~mm}$ compr., soldados na base, cilíndricos; pistilódio cônico, trisulcado desde a base, imerso no tubo, à altura da inserção dos filetes, ca. $0,3 \mathrm{~mm}$ compr. Inflorescências pistiladas em espigas eretas, $3-8 \mathrm{~cm}$ compr.; flores com perianto campanulado, amarelado, esverdeado ou alaranjado, isoladas em cada nó floral, com bráctea e profilo ovado-lanceolados, ca. $0,5 \mathrm{~mm}$ compr.; tépalas internas e externas oblongo-ovadas, 1,2-
$2 \mathrm{~mm}$ compr., soldadas até $2 / 3$ da sua altura; gineceu tricarpelar, colunar, cilíndrico, estiletes soldados na base e livres no ápice; ramos simples, agudos; estaminódios 6, branco-amarelados, ca. $1 \mathrm{~mm}$ compr., rudimentos de anteras ovais, inseridos na base do tubo, próximos ao estilete. Cápsulas 0,5-1,5cm compr., quadrangulares a oblongas, valvas amareladas a alaranjado-escuras, rugosas, com restos do perigônio no ápice; margens dilatadas no fruto. Sementes ca. $2 \mathrm{~mm}$ compr., centrais, ovalcirculares, alaranjadas, com ala circular rugosa.

Material examinado: Minas Gerais: Santana do Riacho, serra do Cipó, 1957, E.P. Heringer 9452 (UB); Serro, Lapinha, 23.II.1968, H.S. Irwin et al. s.n. (UB); $29 \mathrm{~km}$ a sudoeste de Diamantina, 14.I.1969, H.S. Irwin et al. s.n., fr. (UB); $15 \mathrm{~km}$ a nordeste de Diamantina, 26.I.1969, H.S. Irwin et al. 22591, fl. masc. (UB); $12 \mathrm{~km}$ ao norte de Diamantina, 27.I.1969, H.S. Irwin et al. s.n. (UB); a 8km de Joaquim Felício, 7.III.1970, H.S. Irwin et al. s.n., fr. (UB); Diamantina, $10 \mathrm{~km}$ ao norte de São João da Chapada, 22.III.1970, H.S. Irwin et al. s.n. (UB): Santa Bárbara, serra do Caraça, 23.I.1971, H.S. Irwin et al. s.n. (UB); Diamantina, 16.II.1973, G. Hatschbach \& Ahumada 31648, p.p., fl. masc. (MBM): Diamantina, 16.II.1973, G. Hatschbach $\mathcal{E}^{2}$ Ahumada 31648, p.p., fr. (MBM); estrada Curvelo-Diamantina, 13.XII.1974, N. Menezes $\dot{\mathcal{F}}$ C. Froelich 1197 , fl. masc. (SPF); Couto Magalhães, 26.II.1975, G. Halschbach 36516, fl. fem., fr. (MBM); $7 \mathrm{~km}$ ao norte de São João da Chapada, Diamantina, 29.III.1979, H.S. Irwin et al. s.n. (UB): Diamantina, estrada para Couto Magalhães, 15.XII.1979, $G$. Martinelli $\mathcal{E}$ Smith 6278, fl. masc. (RB); Santana do Riacho, Serra do Cipó, 7.XI.1980, I. Cordeiro et al. 6698 pr.p., fl. masc. (SPF); Santana do Riacho, Serra do Cipó, 7.XI.1980, I. Cordeiro et al. 6698 pr.p., fl. fem., fr. (SPF); Diamantina, estrada para São João da Chapada, 12.XII.1980, N. Menezes el al. 556, fl. masc. (SPF); Joaquim Felício, estrada para a Serra do Cabral, 17.IV.1981, L. L. Rossi et al. 1097, fl. fem., fr. (SPF); Diamantina, km 15 da estrada para Biribiri, 2.XII.1981, N. Hensold 385, fl. masc. (SPF); Santo Antônio do Itambé, Pico do Itambé, 6.IV.1982, L. Rossi et al. 3088, fl. masc. (SPF); Diamantina, 7.XII.1984, Ferreira 3731, fl. fem., fr. (GUA); Gouveia, Barro Preto, 29.XI.1985, G. Hatschbach E Silva 50317 pr.p., fl. masc. (MBM); Gouveia, Barro Preto, 29. XI.1985, G. Hatschbach E Silva 50317 pr.p., fl. fem., fr. (MBM); Diamantina, 18.XII.1985, R. Simão et al. 8779, fl. masc. (SPF); Itacambira, 9.I.1986, I. Cordeiro et al. 9172, fl. masc. (SPF, K); Ouro Preto, APA da Cachoeira das Andorinhas, 21.I.1986, D. Araujo 7159, fl. masc. (GUA); Ouro Preto, Lavras Novas, 25.I.1986, A. Giulietti et al. 9215, fl. masc. (SPF); Diamantina, estrada para Conselheiro Mata, 28.I.1986, D. Zappi et al. 9356 (SPF); Diamantina, 10.I.1987, P. Braga s.n., fl. masc. (BHCB); Diamantina, 10.I.1988, J.R. Pirani et al. 11808, fl. masc. (SPF); Ouro Preto, APA Cachoeira das Andorinhas, 10.XI.1993, Teixeira E' Oliveira s.n., fl. masc. (HXBH); Mariana, Estrada Real, 11.XI.1993, Teixeira Eं Oliveira s.n., fl. masc. 


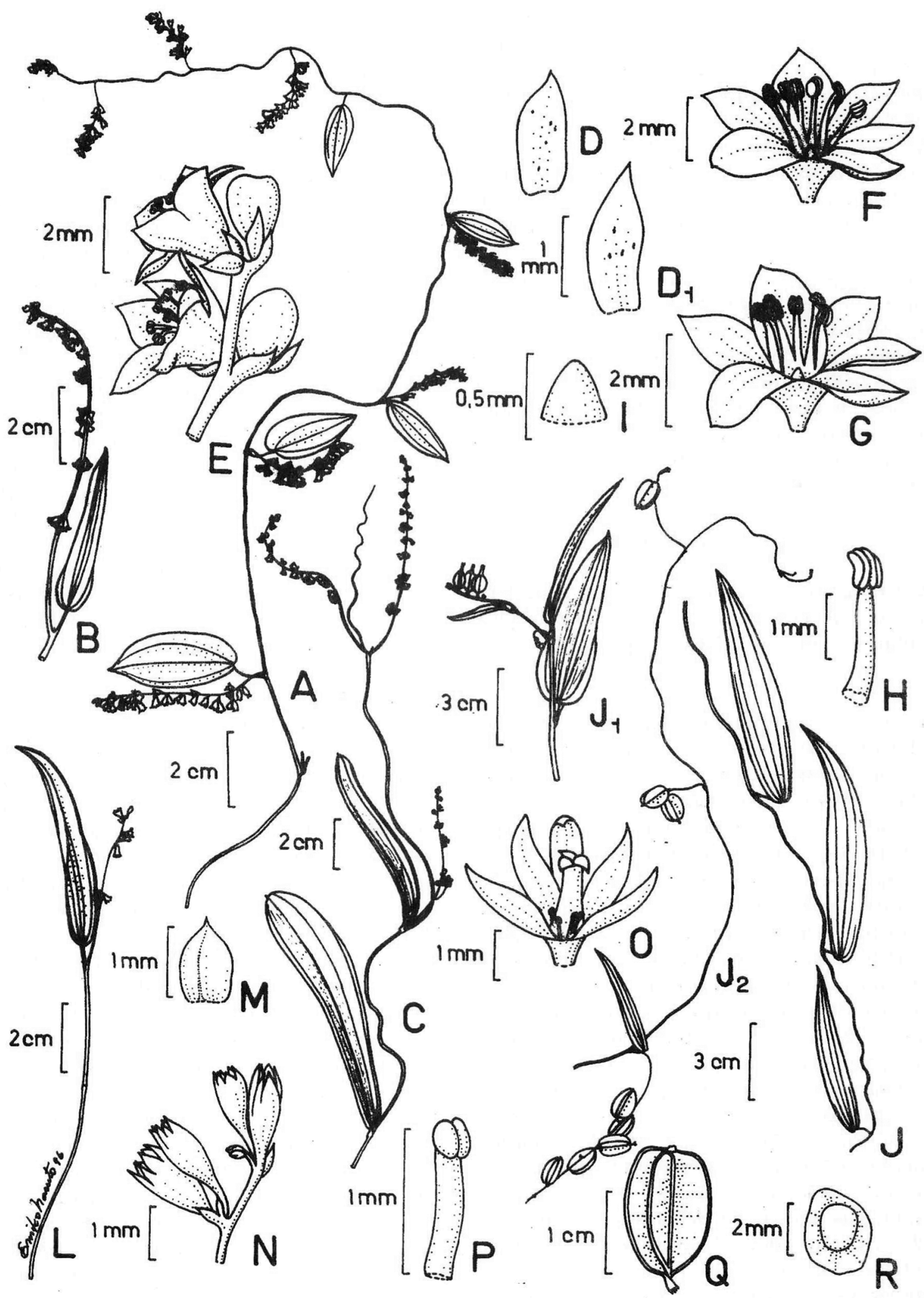

Fig. 14: Dioscorea maianthemoides Griseb. A-C. ramos floríferos (planta masculina); D-I. flor estaminada; D. profilo; D1. bráctea; E. f lores em antese, brácteas e profilos; F-G. perigônio, estames e pistilódios; H. estame; I. pistilódio; J. ramo com folhas (planta feminina); J1-J2. ramos floríferos (planta feminina); L. seção do ramo florífero e flores pistiladas; M-P. flor pistilada; M. bráctea; N. flores em antese, brácteas e profilos; O. perigônio, estaminódios, estilete e estigma; P. estaminódio; Q. cápsula; R. semente. (A-I: Pedralli Ẽ Teixeira 3444; J-P: Ferreira 3731; Q-R: Rossi et al 1097) 
(HXBH); Serro, a $41 \mathrm{~km}$ da sede, 25.XI.1993, G. Pedralli $\mathcal{E}$ Teixeira 3445, fl. masc. (HXBH); Serro, a $41 \mathrm{~km}$ do trevo para Datas, 25.XI.1993, G. Pedralli E Teixeira 3446, fl. masc. (HXBH); Diamantina, km 20, estrada nova para Conselheiro Mata, 25.XI.1993, G. Pedralli E Teixeira 3444, fl. masc. (HXBH); Joaquim Felício, serra do Cabral, 17.I.1996, G. Hatschbach, M. Hatschbach 64257 E J Silva, fl. masc. (MBM); Joaquim Felício, subida da serra do Cabral, 14.IV.1996, G. Hatschbach 64745, A. Schinini Eं J. Silva, fl. masc. (MBM).

Distribuição geográfica e hábitats: Dioscorea maianthemoides apresenta distribuição neotropical e exclusiva do Brasil e distribui-se pelos campos rupestres da Cadeia do Espinhaço em locais abertos, ensolarados, em solos arenosos ou pedregosos, bem drenados ou úmidos, em geral pobres em nutrientes e entre fendas nos afloramentos rochosos. Ocorre, ainda, nos cerrados próximos aos campos rupestres nos estados de Goiás, Distrito Federal e em Minas Gerais.

14. Dioscorea microbotrya Griseb., Symb. Fl. Arg., p. 322. 1879.

Tipo: Argentina, "Prov. Entreríos, Concepción del Uruguay, raro in fruticetis ripariis", Lorentz 130 pr. p., planta masculina (Lectótipo B!; Isolectótipo CORD n.v.). Fig. 15

Plantas dióicas. Sistema subterrâneo constituído por um rizóforo axial (ca. $10 \mathrm{~cm}$ compr.), profundo, do qual se partes espessadas pequenas semelhantes a 'batatas', suculentas, esféricas, $2-5 \mathrm{~cm}$ diâm.; periderme marrom a acinzentada e medula branca, amarelada ou purpúrea. Das partes espessadas brotam raízes longas, filiformes, fibrosas, marrons, fasciculadas. Lianas com ramos perenes, esverdeados a castanho-escuros, dextrogiros, sem expansões laterais, 1-3m compr., glabros ou papilosos, 1-5mm diâm. Caules jovens em seção transversal circulares, quando mais velhos poligonais, marrons a castanho-escuros, canaliculados ou, ainda, aplanados centralmente. Folhas simples, alternas, ovado-oblongas a deltóides, cordadas a hastadas, ápice obtuso a truncado, ou, ainda, aristado; cartáceas, glabras, esverdeadas, com 7-9 nervuras salientes em ambas as faces, bordo inteiro a crenado, $3-15 \mathrm{~cm}$ compr.; pecíolos robustos, canaliculados, $1,5-9 \mathrm{~cm}$ compr., retorcidos na inserção no caule, alaranjados a castanho-escuros. Inflorescências estaminadas cimosas, em dicásios pauci a multifloros, $10-25 \mathrm{~cm}$ compr.; flores isoladas, sésseis, bráctea e profilo elíptico-lanceolados, ca. $1 \mathrm{~mm}$ compr., hialinos, com pontuações avermelhadas na base; flores com perianto rotáceo, amarelado, esverdeado ou violáceo; tépalas internas e externas largamente ovadas, $1-2 \mathrm{~mm}$ compr., ungüiculadas; estames 6 , em dois ciclos ou ciclo único, inseridos na base das tépalas, em redor do pisti- lódio; anteras até $0,1 \mathrm{~mm}$ compr., introrsas, oval-alongadas, deiscência longitudinal, em geral 3 sésseis e 3 com filetes curtos, ou todas pediceladas, ou, ainda, todas sésseis; filetes quando presentes grossos, cilíndricos; pistilódio curto, aplanado, trígono, com 3 sulcos divergentes, ca. $0,2 \mathrm{~mm}$ compr. Inflorescências pistiladas em espigas simples, paucifloras a multifloras, pêndulas, $8-20 \mathrm{~cm}$ compr.; flores com perianto campanulado, amarelado, esverdeado, alaranjado ou purpúreo; isoladas em cada nó floral, sésseis; bráctea oblongo-lanceolada, ca. $0,2 \mathrm{~mm}$ compr. Tépalas internas e externas oblongo-agudas, 1-1,5mm compr.; gineceu tricarpelar, colunar, globoso no ápice, dividido em 2 ou 3 ramos amarelados, estaminódios oblongo-elípticos, ca. 1,2 mm compr., inseridos a 1/3 da altura das tépalas. Cápsulas 2-3,5cm compr., elípticas a deltóide-poligonais (de perfil), base truncada, ápice com restos do perigônio, pedicelo ca. $3 \mathrm{~mm}$ compr. ou sésseis; valvas amareladas a esverdeadas (ao vivo), quando secas castanho-escuras, margens simples a levemente dilatadas. Sementes centrais nos frutos maduros, ca. $1 \mathrm{~cm}$ compr., ovaladas, amareladas ou alaranjado-escuras, com ala circular dilatada em direção ao ápice, lisa ou reticulada.

Material examinado: Bahia: Lençóis, Morro da Chapadinha, 23.XI.1994, E. Melo et al. 1296, fl. masc. (ALCB). Minas Gerais: Mariana, passagem de Mariana, 11.XI.1969, J. Badini 623, fl. masc. (EM); Itambé do Mato de Dentro, Pico do Itambé [vertente leste da Serra do Cipó], 13.II.1972, W. Anderson et al. 35927, fr. (UB); Belo Horizonte, campus da UFMG, Estação Ecológica, 13.VI.1990, E. Bacariça et al. 48, fr. (BHCB, HXBH); Belo Horizonte, campus da UFMG, Estação Ecológica, 13.VI.1990, E. Bacariça et al. 53, fl. masc. (BHCB, HXBH); Belo Horizonte, campus da UFMG, Estação Ecológica, 5.II.1991, E. Bacariça 103, fl. masc. (BHCB, HXBH); Cardeal Mota, Serra do Cipó, base da Serra do Calcário, 22.VII.1993, M. Campos et al. 13276, fl. fem., fr. (SPF); Ouro Preto, Estação Ecológica do Tripuí, próximo à casa abandonada do Sr. João Lopes, 2.IX.1993, Teixeira s.n., fl. fem., fr. (HXBH); Ouro Preto, Estação Ecológica do Tripuí, próximo à casa do João Lopes, 10.XI.1993, Teixeira E Oliveira s.n., fl. masc. (HXBH); Conceição do Mato Dentro, a $3 \mathrm{~km}$ do trevo para Morro do Pilar, 26.XI.1993, G. Pedralli 3448, fl. masc. (HXBH); Ouro Preto, Estação Ecológica do Tripuí, próximo à casa do Sr. João Lopes, 14.XII.1993, Teixeira et al. s.n., fr. (HXBH); Ouro Preto, Estação Ecológica do Tripuí, próximo à casa do Sr. João Lopes, 18.II.1994, G. Pedralli $\mathcal{E}$ Teixeira s.n., fl. masc. (HXBH); Ouro Preto, Estação Ecológica do Tripuí, 18.II.1994, G. Pedralli E Teixeira s.n. (HXBH).

Distribuição geográfica e hábitats: com distribuição neotropical e exclusiva da América do Sul, na Cadeia do Espinhaço a espécie cresce em locais sombreados 


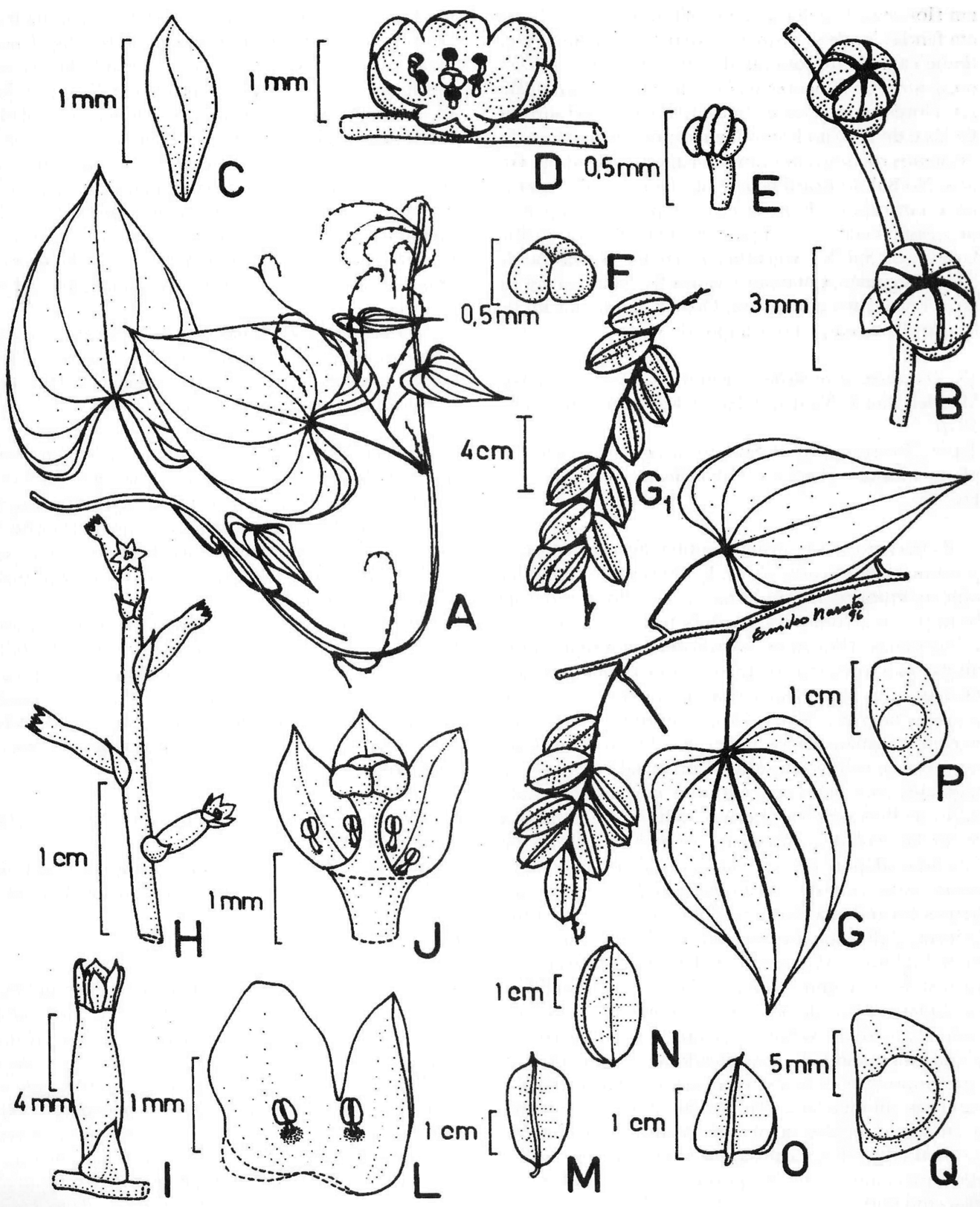

Fig. 15: Dioscorea microbotrya Griseb. A. ramo florífero (planta masculina); B-F. flor estaminada; B. flores jovens; C. bráctea; D. perigônio, estames e pistilódio; E. estame; F. pistilódio; G-G1. ramos floríferos (planta feminina); H-L. flor pistilada; H. flores em antese e brácteas; I. flor em antese e bráctea; J. tépalas, estaminódios, estilete e estigma; L. tépalas e estaminódios; M-O. cápsulas; P-Q. sementes. (A-F: Pedralli Ev Teixeira s.n.; G-Q: Teixeira s.n.) 
em florestas de galeria ou em afloramentos rochosos em fendas, onde se acumulam detritos formando uma tênue camada de solo úmido, protegido do sol. Dioscorea microbotrya ocorre na borda de florestas de galeria, florestas estacionais (mesófilas), nos cerrados de Goiás e do Distrito Federal, em capões de mata e afloramentos rochosos nos campos rupestres de Minas Gerais. No Sul do Brasil ocorre nas Florestas de Araucária e em capões de mata nos campos da campanha, depressão central e campos de cima da serra do Rio Grande do Sul. Na Argentina ocorre nas províncias de Salta, Tucumán, Catamarca, Córdoba, Santiago del Estero, Entre Ríos e Misiones. Ocorre, ainda, no sul do Chaco (Paraguai) e nos campos do Uruguai.

15. Dioscorea monadelpha (Kunth) Griseb., Vidensk. Meddel. Dansk. Naturhist. Foren. Kjobenhazen, p. 164. 1875.

Tipo: "Brasilien, ohne Standortsangabe", Sellow 55, planta monóica (Lectótipo B!; Isolectótipo K!).

Fig. 16

Plantas monóicas. Sistema subterrâneo constituído por um rizóforo carnoso, ca. 1,5cm compr., sem substâncias lipídicas na epiderme, profundo, periderme branca a marrom-clara, medula branca, com raízes fasciculadas, filiformes, amareladas, alaranjadas ou, ainda, marrom-escuras. Lianas com ramos perenes, esverdeados, amarelados a castanho-escuros, sem expansões laterais, dextrogiros, sempre volúveis, 0,5-2 m compr., canaliculados, pubérulos, 1-2mm diâm. Caules jovens e velhos em seção transversal circular-pentagonais, com pêlos concentrados nos ângulos caulinares. Folhas simples, alternas, deltóides, sagitadas a ovado-lanceoladas, cartáceas, tricomas papilosos na face adaxial, pubérulas na face abaxial, $3-8 \mathrm{~cm}$ compr., amareladas, esverdeadas a oliváceas, 5-9 nervuras salientes em ambas as faces; pecíolos delgados, marromescuros, delicados, canaliculados, $2-5 \mathrm{~cm}$ compr., glabros. Inflorescências estaminadas em racemos paucifloros, $3-7 \mathrm{~cm}$ compr.; flores isoladas em cada nó floral; bráctea e profilo oblongo-acuminados, 0,5-1,2mm compr., amarelo-esverdeados; flores com perianto campanulado, amarelado, esverdeado a castanho-escuro, com pontuações escuras esparsas; tépalas internas e externas oblongo-lanceoladas, $6-8 \mathrm{~mm}$ compr.; estames 3 , anteras inseridas na metade da altura da coluna estaminal cilíndrica, carnosa, com expansão apical, variável no comprimento e espessura; anteras oval-oblongas, com deiscência longitudinal. Inflorescências pistiladas em espigas, pêndulas, $5-15 \mathrm{~cm}$ compr.; flores com perianto rotado, amarelo-esverdeado (ao vivo) ou castanho-escuro (em material seco), isoladas em cada nó floral, sésseis; bráctea e profilo oblongo-apiculados, 0,6-1,2mm compr.; perianto campanulado, amareloesverdeado; tépalas internas e externas oblongo-lanceoladas, ca. 1,2mm compr.; gineceu tricarpelar, estiletes divergentes, com a base inserida em um disco glanduloso, amarelo-esverdeado, ramos oblongo-lanceolados, branco-amarelados. Cápsulas 1-1,5cm compr., oblongas, esverdeadas (ao vivo) ou castanho-escuras (em material seco), com restos do perigônio no ápice, margens dilatadas e pontuações escuras distribuídas irregularmente na metade superior. Sementes ca. $4 \mathrm{~mm}$ compr., circulares a ovais, alaranjadas a castanho-escuras, lisas, com ala circular, irregular, mais alargada na base.

Material examinado: Minas Gerais: Lagoa Santa, estrada para a Serra do Cipó, VII.1911, Uline s.n., fl. masc., fl. fem., fr. (B); Ouro Preto, estrada para São Bartolomeu, 21.IX.1993, G. Pedralli 3410, fl. masc. (HXBH).

Distribuição geográfica e hábitats: a espécie apresenta distribuição neotropical e exclusiva da América do Sul, e na Cadeia do Espinhaço ocorre na beira e no interior de florestas de galeria e capões de mata, sempre em locais úmidos, sombreados, em solos ricos em matéria orgânica e nos cerrados típicos, em solos argilosos, à sombra das árvores.

Dioscorea monadelpha distribui-se desde o Nordeste, Centro-Oeste e Sudeste até o Sul do Brasil no Rio Grande do Sul, habitando o interior de florestas de galeria, florestas pluviais (Mata Atlântica) e florestas temperadas, a borda de capões de mata e o interior de cerrados. Atinge, ainda, o Peru, Bolívia, Paraguai, Argentina e Uruguai.

16. Dioscorea orthogoneura Hochr., Bull. New York Bot. Gard. 6(1): 267. 1910.

Tipo: Brasil, "Goyaz, zwischen Meiaponte und Caisarea", [23.X.1827], Burchell 6306 pr. p., planta masculina (Lectótipo, K!).

Fig. 17

Plantas dióicas. Sistema subterrâneo constituído por um rizóforo carnoso, ca. $3 \mathrm{~cm}$ compr. e $3 \mathrm{~cm}$ profundidade, filiforme, do qual se originam raízes fasciculadas, marrom-escuras; periderme branco-amarelada, medula alva. Lianas com ramos perenes, esverdeados, alaranjados a castanho-avermelhados, sem expansões laterais, dextrogiros, eretos ou apoiantes sobre árvores $\mathrm{e}$ arbustos próximos, 0,5-3m compr., muricados, com pontuações avermélhadas distribuídas irregularmente, $1-3 \mathrm{~mm}$ diâm. Caules jovens e velhos circulares em seção transversal, os jovens esverdeados, os mais velhos avermelhado-escuros. Folhas simples, alternas, oblongas, oblongo-lanceoladas, deltóides a sagitadas, com 'sinus' pronunciado, membranáceas a cartáceas, gla- 
Levantamento das Dioscoreaceae (R. Br.) Lindley da Cadeia do Espinhaço, Minas Gerais e Bahia

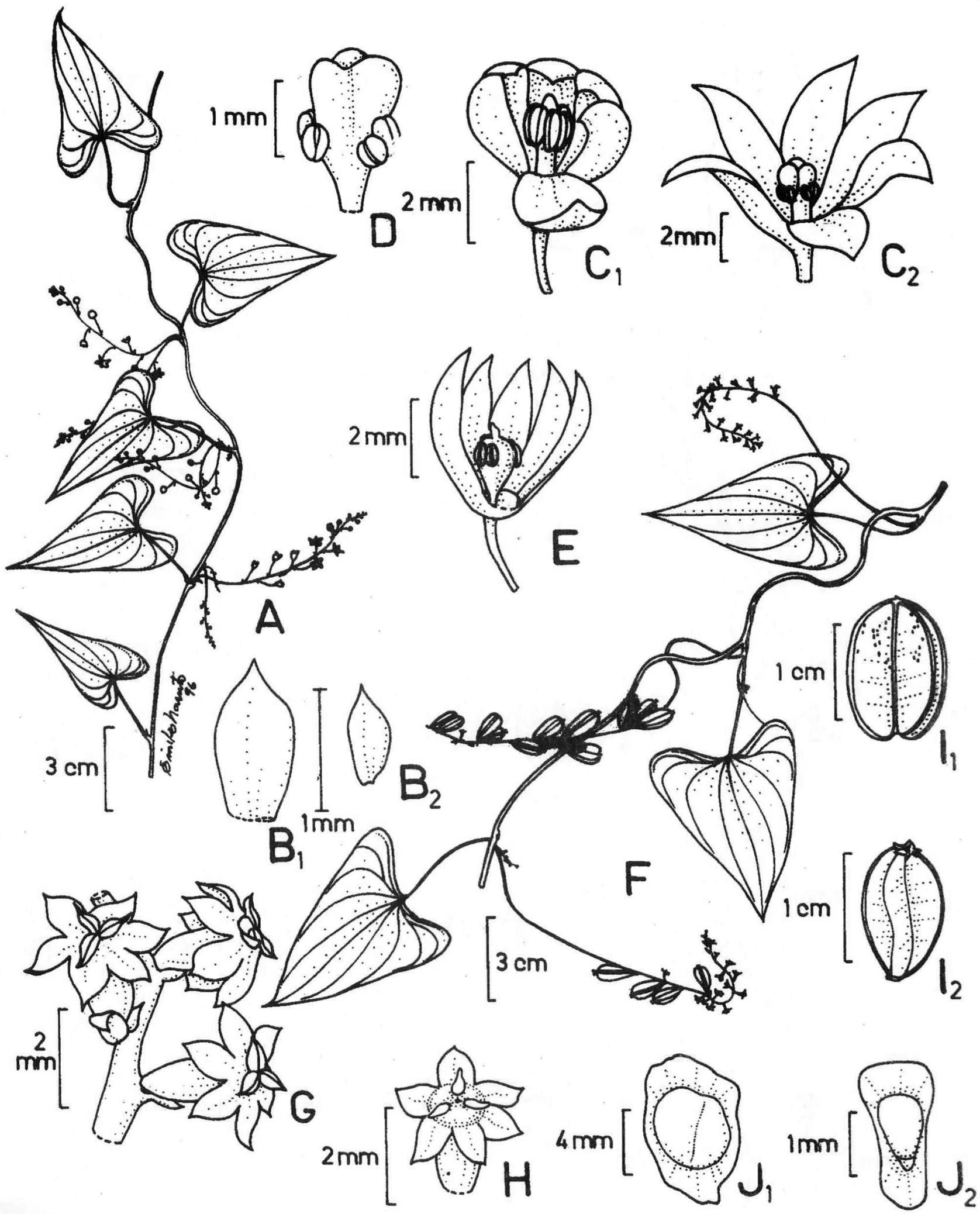

Fig. 16: Dioscorea monadelpha (Kunth) Griseb. A. ramo florifero com flores estaminadas; B1-E. flor estaminada; B1. bráctea; B2. profilo; C1C2. perigônio, coluna estaminal e anteras; D. coluna estaminal; E. tépalas, coluna estaminal e anteras; F. ramo florífero com flores pistiladas; G-H. flor pistilada; G. flores em antese, brácteas e profilos; H. perigônio e estiletes; I1-I2. cápsulas; J1-J2. sementes. (A-E: Pedralli 3410; F-J2: Uline s.n.) 


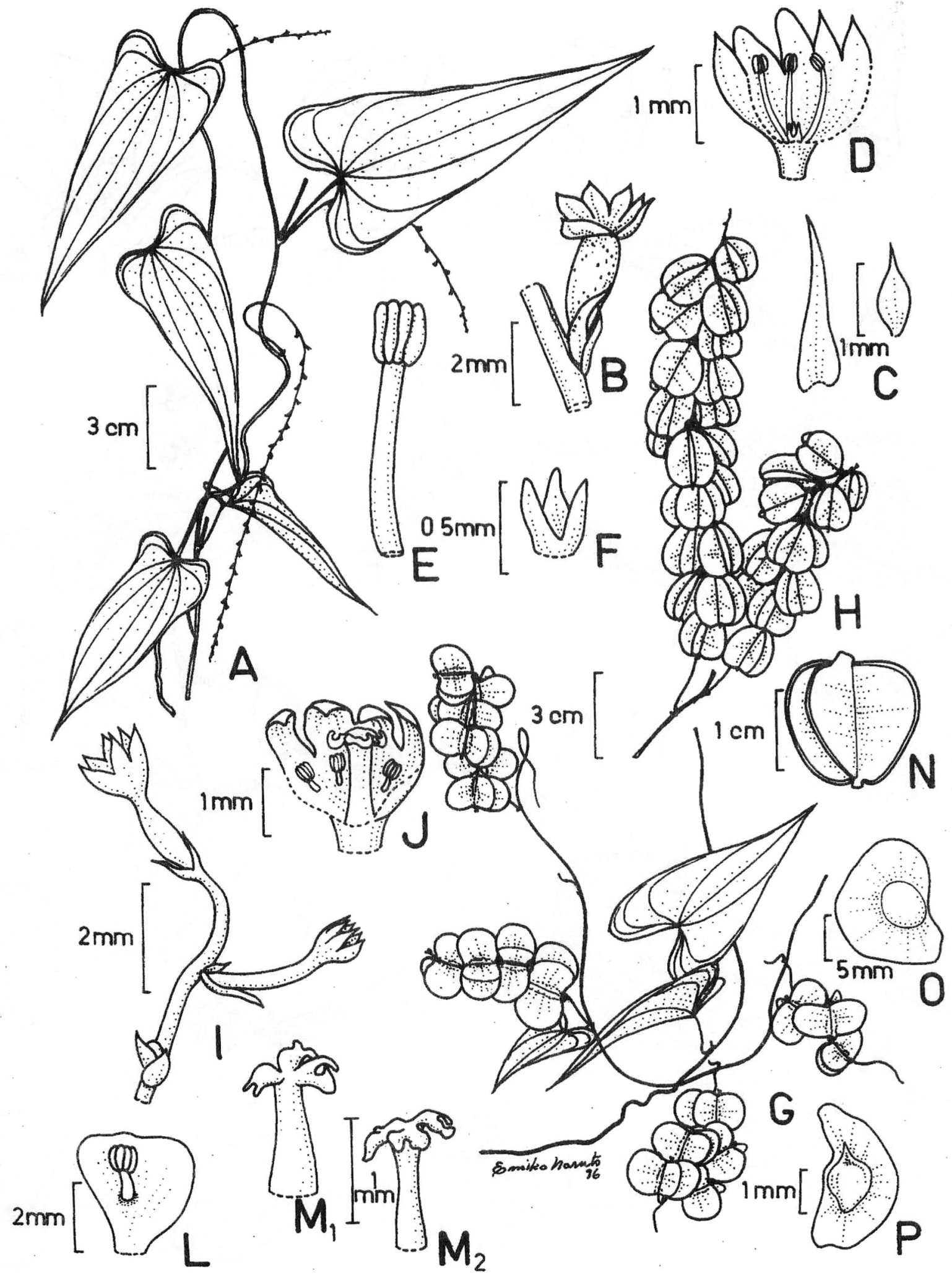

Fig. 17: Dioscorea orthogoneura Hochr. A. ramo florífero (planta masculina); B-F. flor estaminada; B. flor em antese, bráctea e profiro; C. bráctea (maior) e profilo; D. perigônio, estames e pistilódio; E. estame; F. pistilódio; G-H. ramos floríferos; I-L. flor pistilada; I. flores em antese, brácteas e profilos; J. perigônio, estaminódios, estilete e estigma; L. tépala e estaminódio; M1-M2. estiletes e estigmas; N. cápsula; O.P- sementes. (A-F: Queiroz 643; G-O: Pedralli 3381) 
bras, opacas, esverdeadas, oliváceas a castanho-escuras, 3-7 nervuras salientes em ambas as faces, $3-18 \mathrm{~cm}$ compr.; pecíolos robustos, amarelados, glabros, $1-6 \mathrm{~cm}$ compr. Inflorescências estaminadas em espigas, $2-12 \mathrm{~cm}$ compr., flores isoladas em cada nó floral; bráctea triangular-acuminada, 1,4-2,2mm compr., profilo oblongoapiculado, ca. 1,2mm compr., ambos com pontuações avermelhadas esparsas; flores com perianto campanulado, amarelo-esverdeado, com pontuações avermelhadas distribuídas irregularmente ao longo do tubo; tépalas internas e externas oblongo-lanceoladas, 1-2mm compr.; estames 3, inseridos na base do tubo, próximos ao pistilódio; anteras ca. $0,3 \mathrm{~mm}$ compr., introrsas, paralelas, oval-oblongas, deiscência longitudinal, filetes longos, ca. $1 \mathrm{~mm}$ compr., cilíndricos, curvos na posição superior próximo às anteras; pistilódio curto, crasso, ca. 0,5mm compr.; estilódios 3, divergentes, linear-lanceolados, ca. 0,4mm compr. Inflorescências pistiladas em espigas, eretas ou pêndulas; flores com perianto campanulado, alaranjado a castanho-escuro, isoladas em cada nó floral, sésseis, bráctea e profilo linear a oblongo-lanceolados, 0,8-1,2mm compr.; tépalas internas e externas oblongo-lanceoladas, $1-2 \mathrm{~mm}$ compr.; gineceu tricarpelar, colunar, tripartido no ápice, ramos bilobados, divergentes; estaminódios 6, branco-amarelados, inseridos na metade da altura das tépalas, com filetes, ca $3,1 \mathrm{~mm}$ compr., rudimentos de anteras oblongos. Cápsulas $1-2 \mathrm{~cm}$ compr., transversalmente oblongas, valvas amareladas a castanho-escuras, após secas avermelhadas, com restos do perigônio no ápice, margens dilatadas. Sementes ca. $10 \mathrm{~mm}$ compr., circulares, branco-amareladas a alaranjado-claras, lisas, com ala quase circular, estreitada próximo à base.

Material examinado: Bahia: Palmeiras, Morro do Pai Inácio, 29.VI.1983, L.P. Queiroz 643, p.p., fl. masc. (HUEFS); Palmeiras, Morro do Pai Inácio, 29.VI.1983, L.P. Queiroz 643 pr.p., fl. fem. (HUEFS). Minas Gerais: $8 \mathrm{~km}$ a sudeste de Conceição do Mato Dentro, 17.V.1990, M.M. Arbo et al. 4292, fl. fem., fr. (CTES, K); Conceição do Mato Dentro, estrada para Belo Horizonte, margem direita do rio Santo Antônio a $50 \mathrm{~m}$ da ponte, 14.VI.1992, G. Pedralli 3381, fl. fem., fr. ( $\mathrm{HXBH})$.

Distribuição geográfica e hábitats: a espécie apresenta distribuição neotropical e exclusiva da América do Sul. $\mathrm{Na}$ Cadeia do Espinhaço é encontrada no interior de florestas de galeria em locais úmidos, em solos aluvionais ou sobre restos vegetais em decomposição, sobre pedras ou em fendas nos afloramentos rochosos dos campos rupestres. Na Serra do Espinhaço foram observados indivíduos crescendo sobre espécies de Vellozia (Velloziaceae).

Dioscorea orthogoneura ocorre na Venezuela, nas Guia- nas e na Bolívia, no interior de florestas pluviais. No Brasil, distribui-se pelos estados do Nordeste, CentroOeste e em Minas Gerais.

17. Dioscorea ovata Vell., Fl. flum. 10 (ícones): tab. 117. 1831, et in Archos. Mus. Nac. Rio de Janeiro 5: 425. 1881.

Tipo: Vellozo, Fl. flum. 10: tab. 117, ilustração de planta masculina (Lectótipo).

Fig. 18

Plantas dióicas. Sistema subterrâneo constituído por um rizóforo curto, com tuberosidade axial discóide ou irregular, superficial ou profundamente enterrada (até $50 \mathrm{~cm}$ ), comprimida dorsalmente, com ponto vegetativo central, apical, do qual brotam longas raízes delgadas, fibrosas; periderme acinzentada a castanho-escura e medula branco-amarelada. Lianas com ramos perenes, esverdeados, amarelados a castanho-escuros, sem expansões laterais, dextrogiros, eretos até ca. $1 \mathrm{~m}$ alt., depois volúveis, 0,5-3m compr., glabros a pilosos, 1-2,5 mm diâm.; pilosidade mais densa próximo à inserção dos pecíolos foliares. Caules jovens em seção transversal circulares, canaliculados, quando mais velhos pentagonais a poligonais, recobertos por pontuações pequenas, avermelhadas ou escuras. Folhas simples, alternas, ovadas a cordiformes, acuminadas, cordadas, carnosas ao vivo, membranáceas após herborização, glabras, esverdeadas a castanho-escuras, 7 nervuras salientes em ambas as faces, margem crenada, $3-10 \mathrm{~cm}$ compr.; pecíolos robustos, amarelados, glabros, canaliculados, $0,5-8 \mathrm{~cm}$ compr. Inflorescências estaminadas em racemos ou panículas, $6-40 \mathrm{~cm}$ compr., flores $3-8$ por nó; bráctea lanceolada a triangular-acuminada, ca. $0,8 \mathrm{~mm}$ compr.; flores com perianto infundibuliforme, branco-esverdeado a alaranjado, com pontuações avermelhadas. Tépalas internas e externas triangular-ovadas, 1-1,2mm compr.; estames 6 , soldados na base, inclusos no tubo, anteras ca. $0,5 \mathrm{~mm}$ compr., extrorsas, elíptico-ovadas, deiscência longitudinal, filetes $0,5-1 \mathrm{~mm}$ compr., achatados na base, depois cilíndricos; pistilódio crasso, cônico, com três sulcos longitudinais, ca. $0,2 \mathrm{~mm}$ compr. ou nulo. Inflorescências pistiladas em espigas, pêndulas, $5-15 \mathrm{~cm}$ compr.; flores com perianto campanulado, amarelado a alaranjado-escuro, isoladas em cada nó floral, sésseis; bráctea e profilo triangularovados, 0,8-2mm compr., com pontuações avermelhadas no terço inferior; perianto campanulado, brancoesverdeado a amarelado; tépalas internas e externas oblongo-acuminadas, 1-2mm compr.; gineceu tricarpelar, colunar, dilatado na base, tripartido no ápice, ramos estigmáticos bífidos, globosos; estaminódios 6 , amarelados, pedicelados, ca. $1 \mathrm{~mm}$ compr., rudimentos de anteras ovados, amarelados. Cápsulas $1-1,5 \mathrm{~cm}$ com- 


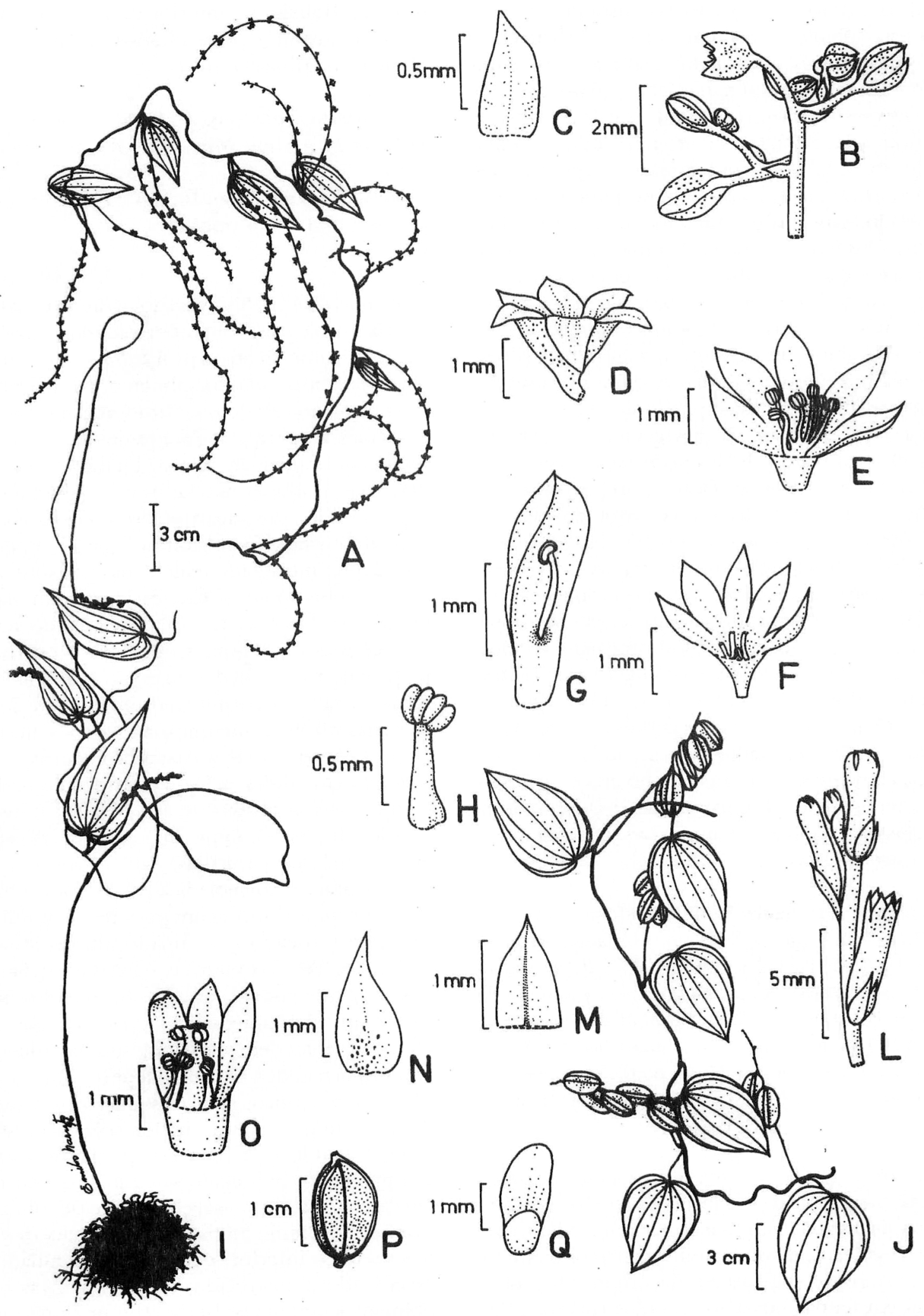

Fig. 18: Dioscorea ovata Vell. A. ramo florífero (planta masculina); B-H. flor estaminada; B. flores jovens e brácteas; C. bráctea; D. flor em antese; E. perigônio e estames; F. perigônio e pistilódio; G. tépala e estame; H. estame; I. ramo florífero e rizóforo com tuberosidade (planta feminina); J. ramo em frutificação; L-O. flor pistilada; L. flores em antese, brácteas e profilos; M. bráctea; N. profilo; O. tépalas, estaminódios, estilete e estigma; P. cápsula; Q. semente. (A-H: Pedralli Ẽ Teixeira 3438; I-Q: Pedralli 3394) 
pr., elíptico-oblongas, glabras a pilosas, pilosidade concentrada na soldadura das valvas; valvas amareladas a alaranjadas, com restos do perigônio no ápice, margens dilatadas e densa pontuação avermelhada em toda superfície. Sementes ca. $4 \mathrm{~mm}$ compr., rugosas, circulares, alaranjado-escuras, com asa apical com ca. $7,5 \mathrm{~mm}$ compr.

Material examinado: Bahia: $22 \mathrm{~km}$ a noroeste de Lagoinha, 6.III.1974, R.M. Harley 16874 (RB); Morro do Chapéu, rio do Ferro Doido, 1.III.1977, R.M. Harley 19194, fl. masc. (UEC). Minas Gerais: Belo Horizonte, Caetano Furquim, 17.I.1933, H. Mello Barreto 2400 pr.p., fl. masc. (BHMH, R); Belo Horizonte, Freitas, 17.I.1933, H. Mello Barreto 2400 pr.p., fl. fem. (BHMH); $20 \mathrm{~km}$ ao sul de Belo Horizonte, II.1945, Willians 5487, fl. fem., fr. (R); Grão Mogol, 19.II.1993, G. Pedralli 3394, fl. fem., fr. (HXBH); Várzea da Palma, Serra da Macineta, sul da Serra do Cabral, 23.XI.1993, G. Pedralli 3428 , fl. masc. (HXBH); Várzea da Palma, Serra da Macineta, Serra do Cabral, 23.XI.1993, G. Pedralli 3429, fl. masc. (HXBH); Santo Hipólito, a 12km de Corinto, 24.XI.1993, G. Pedralli 3438 E Teixeira, fl. masc. (HXBH); Ouro Preto, Estação Ecológica do Tripuí, Córrego do Apiário, 13.IV.1994, Teixeira $\mathcal{E}$ Santos s.n. (HXBH); Ouro Preto, Estação Ecológica do Tripuí, apiário, 19.IV.1994, G. Pedralli E゚ Teixeina s.n., fl. masc. (HXBH).

Distribuição geográfica e hábitats: D. ovata apresenta distribuição neotropical e exclusiva da América do Sul, e na Serra do Espinhaço ocorre no interior e orla de florestas de galeria em solos aluvionais e em fendas, nos afloramentos rochosos dos campos rupestres, em locais abertos e ensolarados.

Dioscorea ovata ocorre na orla de florestas pluviais tropicais, no interior de florestas de galeria em locais sombreados, em capões de mata e locais abertos nos campos rupestres e restingas da região Sudeste do Brasil. Distribui-se pelos estados do Pará, do Nordeste, Centro-Oeste, Minas Gerais e do Rio de Janeiro até o Rio Grande do Sul. Ocorre, ainda na Argentina, Paraguai, Bolívia e Peru.

18. Dioscorea piperifolia Humb. \& Bonpl. in Willd., Sp. pl., ed. 4, p. 795. 1805.

Tipo: Equador, "crescit in umbrosis, humidis prope Chillo, Lloa et Puembo Quitensium", Humboldt in herb. Willd. 18423, planta masculina (Holótipo B!).

Fig. 19

Plantas dióicas. Sistema subterrâneo constituído por um rizóforo subsuperficial, $1,5-3 \mathrm{~cm}$ profundidade, alongado (ca. $20 \mathrm{~cm}$ compr.), com tuberosidades discóides (2,5 a 3cm diâm.), reticulados, com raízes longas, ramificadas originárias da base envolvendo sua porção média inferior; ponto vegetativo central, saliente; periderme castanho a verde-escura e medula branco-amarelada. Lianas com ramos perenes, esverdeados, amarelados a castanho-escuros, sinistrogiros, 1-3m compr.; ramos jovens eretos ou apoiantes sobre arbustos, pilosos na inserção das folhas, filiformes, circular-elípticos em seção transversal, comprimidos; ramos velhos sempre volúveis, glabros a seríceos, circulares, aplanados, canaliculados. Folhas simples, alternas deltóides a ovais, cordadas, acuminadas, membranáceas, glabras, esverdeadas a castanho-escuras, com 7 nervuras salientes $\mathrm{em}$ ambas as faces, 2,5-5cm compr., pecíolos delicados, filiformes, $1 \mathrm{~m}$ compr. Inflorescências estaminadas racemosas, $4-15 \mathrm{~cm}$ compr., pêndulas a apoiantes; $1-3$ flores por nó floral, aglomeradas; bráctea ovado-acuminada, 1,2-1,6mm compr., pontuações avermelhadas distribuídas longitudinalmente em relação ao eixo central; perianto rotáceo, amarelado, alaranjado ou purpúreo, escuro no centro do disco; tépalas internas e externas oval-oblongas, 1-1,5 mm compr., pontuações avermelhadas no terço superior; estames 6 , sésseis ou subsésseis, inseridos na base das tépalas; anteras ca. $0,3 \mathrm{~mm}$ compr., branco-amareladas, arredondadas a oblongoovais, introrsas a lateral-extrorsas, deiscência longitudinal; pistilódio crasso, cônico, $0,2-0,5 \mathrm{~mm}$ compr., íntegro ou com três sulcos radiais, segmentos papilosos, amarelado-escuros. Inflorescências pistiladas em espigas, pêndulas, $6-12 \mathrm{~cm}$ compr.; flores com perianto campanulado, branco-amarelado ou esverdeado, sésseis, isoladas em cada nó floral; bráctea oval-acuminada, ca. $1,7 \mathrm{~mm}$ compr., profilo elíptico-acuminado, ca. $0,7 \mathrm{~mm}$ compr., ambos amarelados e hialinos; perianto campanulado; tépalas internas e externas oblongo-acuminadas, $3,5-5 \mathrm{~mm}$ compr.; gineceu tricarpelar, estilete crasso, aplanado, dividido a partir da base em 3 ramos divergentes, marrom-escuros, linear-lanceolados, estaminódios ausentes. Cápsulas 0,6-3cm compr., oval-elípticas a quadrangulares, valvas amareladas a alaranjado-escuras, cartáceas a membranáceas, com restos do perigônio no ápice, pontuações avermelhadas, margens dilatadas. Sementes 0,2-1 cm compr., circulares a ovallanceoladas, alaranjadas a marrom-escuras, asa reduzida na base, alongando-se em direção ao ápice, circundando toda a semente.

Material examinado: Bahia: Abaíra, Morro do Zabumba, 30.XII.1991, D.N. Hind et al. 50576, fr. (SPF, CEPEC, HUEFS, K); Abaíra, Morro do Zabumba, 30.XII.1991, D.N. Hind et al. s.n., fl. masc. (SPF, CEPEC, HUEFS, K). Minas Gerais: Mariana, Pico do Itacolomi, I.1892, F. Gomes 65, fl. masc. (EM); Ouro Preto, Santa Rita, XII.1896, A. Silveira 2118, fl. masc. (R); Belo Horizonte, IV.1898, Silveira 2740, fl. masc. (R); Diamantina, VI.1934, A.C. Brade 13576, fl. masc. (RB); Belo Horizonte, Serra do Curral, 13.III.1955, Roth 16458, 


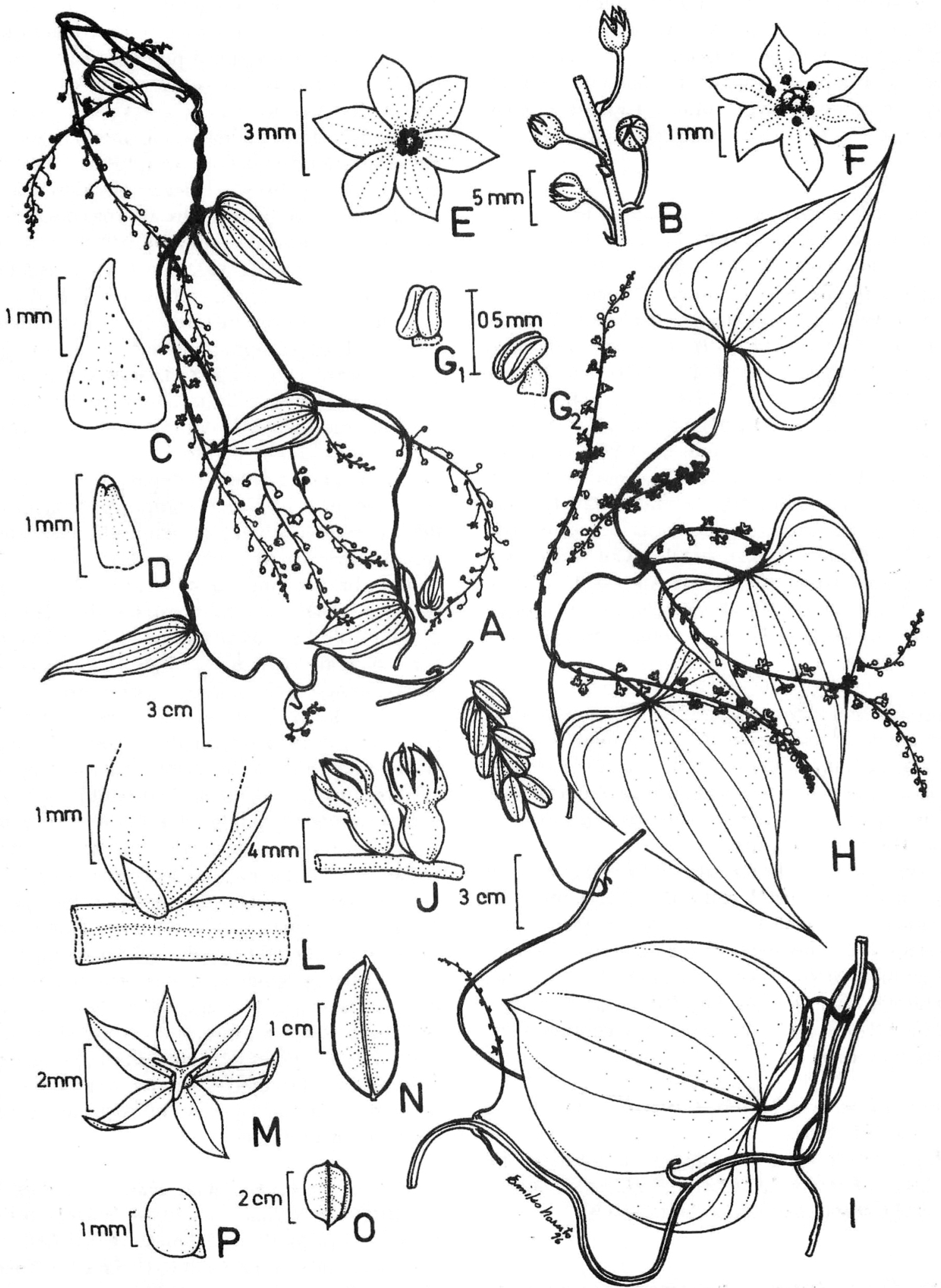

Fig. 19: Dioscorea piperifolia Humb. \& Bonpl. A. ramo florífero (planta masculina); B-G2. flor estaminada; B. flores em antese, brácteas e profilos; C. bráctea; D. profilo; E. perigônio e estames; F. perigônio, estames e pistilódio; G1-G2. estames; H-I. ramos floríferos (planta feminina); J-M. flor pistilada; J. flores em antese e brácteas; L. bráctea e profiro; M. perigônio e estiletes; N-O. cápsulas; P. semente. (A-G2: Pedralli Ẽ Teixeira 3442; H-P: Paula et al. 08) 
fl. fem., fr. (CESJ, CEN); Belo Horizonte, Ressaca, 27.II.1962, Roth 3714, fl. fem., fr. (CESJ, CEN); Diamantina, estrada para Mendanha, 28.I.1969, H.S. Irwin et al. 22784, fl. masc. (UB); Diamantina, São João da Chapada, estrada para Inhaí, 28.III.1970, H.S. Irwin et al. 28548, fl. masc. (UB); Barão de Cocais, 24.I.1971, H.S. Irwin et al. 29003, fl. masc. (UB); Santa Bárbara, Serra do Caraça, 25.I.1971, H.S. Irwin et al. 29070, fl. masc. (UB); Santa Bárbara, Parque Natural do Caraça, 13.XII.1976, H.F. Leitão-Filho et al. 9658 (UEC); Cordisburgo, 26.I.1977, L. Krieger et al. 14520 (CESJ, CEN); Santa Bárbara, Parque Natural do Caraça, 13.XII.1978, H.F. Leitão-Filho et al. 9658, fl. masc. (UEC); Caeté, Serra da Piedade, 27.II.1981, P. Braga et al. 2211 (BHCB); Caeté, Serra da Piedade, 27.II.1986, T. Grandi et al. 2211, fl. masc. (BHCB); Caeté, Serra da Piedade, 5.IV.1986, Paula et al. 08, fl. fem., fr. (BHCB); Diamantina, Gruta do Salitre, 2.I.1987, G. Pedralli $\mathcal{E}$ Teixeira s.n., fl. masc. (HXBH, CEN); Santa Bárbara, Parque Natural do Caraça, 27.X.1993, G. Pedralli Ẽ Teixeira 3414, fl. masc. (HXBH); Caeté, trevo para a Serra da Piedade, 29. X.1993, G. Pedralli E Teixeira 3418, fl. masc. (HXBH); Ouro Preto, margem esquerda do córrego São Bartolomeu, 9.XI. 1993, Teixeira E Oliveira s.n. (HXBH); Ouro Preto, estrada para Santa Rita, 11.XI.1993, Teixeira $\mathcal{E}$ Oliveira s.n., fl. masc. (HXBH); Jequitaí, Serra da Macineta, 23.XI.1993, G. Pedralli $\mathcal{E}$ Teixeira 3426 (HXBH); a $30 \mathrm{~km}$ de Jequitaí, 23.XI.1993, G. Pedralli $\mathfrak{E}$ Teixeira 3427 (HXBH); Santo Hipólito, estrada Corinto-Monjolos, em floresta de galeria do rio Pardo, 24. XI.1993, G. Pedralli E Teixeira 3441 (HXBH); Diamantina, 25.XI.1993, G. Pedralli E Teixeira 3442, fl. masc. (HXBH); 2km de Itambé do Mato de Dentro, 26.XI.1993, G. Pedralli E Teixeira 3449, fl. masc. (HXBH); Mariana, Parque Esta-dual do Itacolomi, trilha para o pico, 15.XII.1993, Teixeira E Oliveira s.n., fl. masc. (HXBH); Belo Horizonte, campus da UFMG, Estação Ecológica, 2.III.1995, J. Lombardi 696 $\mathcal{E}$ L. Temponi, fl. masc. (BHCB, HXBH); Caeté, Serra de Piedade, sem data, Damazio 1486 (EM); Sabará, sem data, Damazio 1489 (EM); Sabará, sem data, Damazio s.n. (RB); Caeté, Serra da Piedade, sem data, Damazio s.n. (RB); Lagoa Santa, sem data, Damazio s.n., pl. masc. (EM, RB).

Distribuição geográfica e hábitats: a espécie apresenta distribuição neotropical e exclusiva da América do Sul. Na Serra do Espinhaço a espécie ocorre na borda de florestas estacionais (mesófilas), interior de florestas de galeria e em fendas nos afloramentos rochosos dos campos rupestres, em locais úmidos, onde se acumulam detritos formando uma pequena camada de solo.

Dioscorea piperifolia possui ampla distribuição geográfica, desde as Guianas, a Colômbia, o Peru, o Paraguai (Chaco) até a província de Misiones no norte da Argentina. No Brasil distribui-se pelos estados do Nordeste, Centro-Oeste, Sudeste até o Sul no Rio Grande do Sul.
19. Dioscorea polygonoides Humb. \& Bonpl. in Willd., Sp. pl., ed. 4, p. 795. 1805.

Tipo: Venezuela, "rio Orinoco", Humboldt in herb. Willd. 18421, planta masculina (Holótipo B!).

Fig. 20

Plantas dióicas. Sistema subterrâneo constituído por um rizóforo alongado (5 a $10 \mathrm{~cm}$ compr.), profundo, carnoso, esbranquiçado, comprimido lateralmente, tuberosidades arredondadas, pequenas (com cerca de 1 $\mathrm{cm}$ diâm.), laterais; periderme castanho-escura e medula alva a marrom-clara. Lianas, com ramos perenes, amarelados a castanho-escuros, sem expansões laterais, dextrogiros, 20-80 cm compr., 1-2mm diâm. Caules jovens e velhos em seção transversal elípticos a quadrangulares, cutícula com ornamentação do tipo papilosa. Folhas simples, alternas, $1-6 \mathrm{~cm}$ compr., orbiculares a oblongo-lanceoladas, acuminadas, membranáceas, glabras, esverdeadas, amareladas a castanho-escuras; lobos basais arredondados, 7 nervuras salientes na face abaxial; pecíolos delicados, canaliculados, $1-2 \mathrm{~cm}$ compr. Inflorescências estaminadas em espigas, $10-23 \mathrm{~cm}$ compr.; flores 2-6 por nó floral; bráctea oblonga, ca. $0,8 \mathrm{~mm}$ compr., profilo oblongo-lanceolado, $1-3 \mathrm{~mm}$ compr.; flores com perianto campanulado, branco-amarelado a esverdeado, com pontuações avermelhadas na base; tépalas internas e externas ovado-triangulares, 0,9$1,2 \mathrm{~mm}$ compr.; estames 3 , inseridos na base das tépalas externas; anteras ca. $0,2 \mathrm{~mm}$ compr., lateral-introrsas, divergentes, ovaladas, lóculos separados ou conectivo largo, apendicular, deiscência livre, filetes ca. 0,3 mm compr., achatados na base, cilíndricos a partir de $1 / 3$ da sua altura; estaminódios 3, curtos, aplanados, bilobados, papilosos, ca. $0,2 \mathrm{~mm}$ compr; pistilódio pequeno, crasso, ca. $0,1 \mathrm{~mm}$ compr., tripartido a partir da metade de sua altura; estilódios 3 , lineares, levemente engrossados, ca. $0,1 \mathrm{~mm}$ compr. Inflorescências pistiladas em espigas, pêndulas, $8-12 \mathrm{~cm}$ compr.; flores com perianto campanulado, amarelado a esverdeado, sésseis, isoladas em cada nó, com bráctea lanceolada, ca. 1,2mm compr. e profilo subulado, ca. 1,0mm compr., na base; tépalas internas e externas obovadas, com pontuações purpúreas a escuras, 0,9-1,2mm compr.; gineceu tricarpelar, cilíndrico, estiletes 3 unidos no terço inferior, livres no ápice, ramos simples, globosos; estaminódios 3 , branco-amarelados, inseridos na base das tépalas externas, com rudimentos de anteras unidos ou separados, sésseis ou com filetes patentes, quadrangulares, globosos ou com apêndice em forma de gancho no ápice do filete, $0,1-0,3 \mathrm{~mm}$ compr. Cápsulas $1-1,5 \mathrm{~cm}$ compr., arredondadas, glabras; valvas amareladas a castanhoescuras, margens dilatadas, crispadas, cartáceas, pedicelo delicado. Sementes ca. 0,4cm compr., circulares, ferrugíneas ou escuras, com asa cartácea, rugosa. 


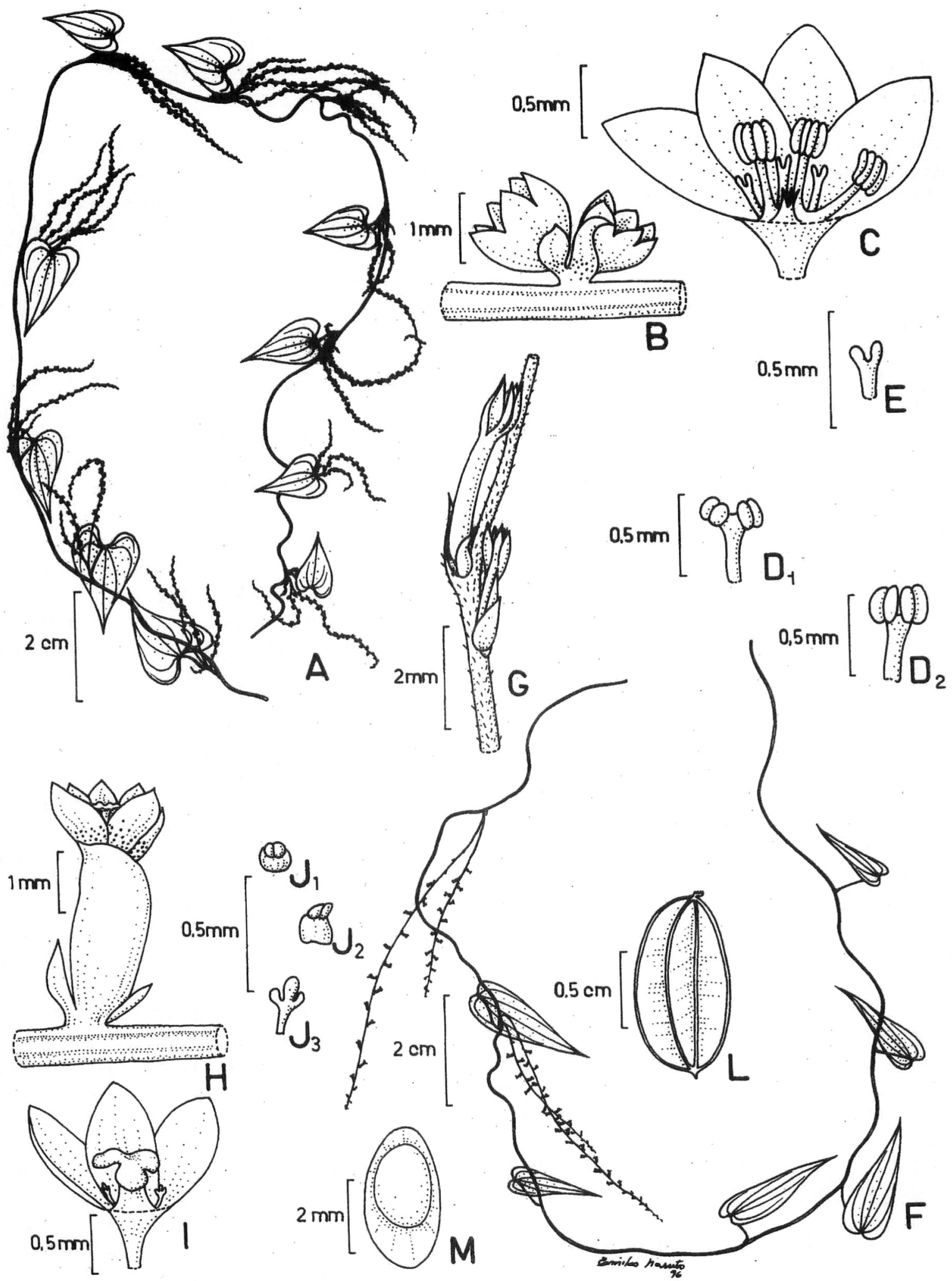

Fig. 20: Dioscorea polygonoides Humb. \& Bonpl. A. ramo florífero (planta masculina); B-E. flor estaminada; B. flores em antese e brácteas; C. perigônio, estames e estaminódios; D1-D2. estames; E. estaminódio; F. ramo florífero (planta feminina); G-J3. flor pistilada; G. flores jovens, brácteas e profilos; H. flor em antese, bráctea e profilo; I. tépalas, estaminódios, estilete e estigma; J1-J3. estaminódios; L. cápsula; M. semente. (A-E: Pedralli 3400; F-M: Irwin et al. 27355) 
Material examinado: Bahia: Morro do Chapéu, 12.V.1957, Lordêlo 323, fl. masc. (ALCB); Piatã, caminho para Capelinha, 14.II.1987, R.M. Harley et al. 24171, fl. masc. (SPF, SP, K); Seabra, terreno baldio perto da rodovia Salvador-Brasília, 23.II.1993, G. Pedralli 3400, fl. masc. (HXBH); Palmeiras, Pai Inácio, 30.VIII.1994, M.L. Guedes 593, fl. masc. (ALCB). Minas Gerais: Ouro Preto, Saramenha, 20.I.1951, Macedo 3033 (SP); Catuni, Serra do Cabral, 8.III.1970, H.S. Irwin et al. 27177, fl. masc. (UB): Joaquim Felício, Serra do Cabral, 10.III.1970, H.S. Irwin et al. 27355 , fl. fem., fr. (UB); Mariana, riacho Mariana, 3.II.1971, H.S. Irwin et al. 29709, fl. masc. (UB).

Distribuiçâo geográfica e hábitats: Dioscorea polygonoides apresenta distribuição neotropical, ocorrendo nas ilhas do Caribe (Porto Rico, em florestas perturbadas), Antilhas (Antigua, Montserrat, Guadalupe, Martinica, Dominica, Santa Lúcia, São Vicente e Granadinas), América Central (México) e do norte da América do Sul (Venezuela) até a Argentina (províncias de Ledesma, Jujuy e Misiones). No Brasil distribui-se pelos estados do Norte, Nordeste, Centro-Oeste, Sudeste até o Sul no Rio Grande do Sul. Habita os cerrados da região Centro-Oeste, as caatingas arbóreas do norte de Minas Gerais e sudeste da Bahia, as restingas da região Sudeste e Sul, as Florestas de Araucária do Sul e os afloramentos rochosos, em locais sombreados e úmidos, dos campos rupestres da Cadeia do Espinhaço.

20. Dioscorea rumicoides Griseb. in Mart. \& Eichl., Fl. bras. 3(1): 42.1842 .

Tipo: Brasil, "Rio de Janeiro", Sellow s.n., planta masculina (Lectótipo B!; Isolectótipos K!, P!).

Fig. 21

Plantas dióicas. Sistema subterrâneo constituído por rizóforo curto (ca. $1 \mathrm{~cm}$ compr.), superficial a profundamente enterrado, com tuberosidade única, axial carnosa, circular ou irregular com lobos superpostos crescendo horizontalmente (ca. $20 \mathrm{~cm}$ compr.); gema vegetativa central; periderme pardo-escura, verrucosa e medula alva. Pequenas raízes esbranquiçadas, simples, se desenvolvem na parte inferior das tuberosidades. Lianas com ramos perenes, esverdeados, amarelados ou alaranjado-escuros, sem expansões laterais, sinistroógiros, eretos ou apoiantes sobre arbustos, 1-3,5m compr., glabros na base, pilosos nos ramos jovens, $1-5 \mathrm{~mm}$ diâm. Caules jovens em seção transversal estreitamente elípticos, canaliculados, pilosos, com córtex pouco desenvolvido; quando mais velhos circulares, pentagonais, canaliculados, glabros, com pontuações avermelhadas esparsas. Folhas simples, alternas, ovais, cordiformes, sagitadas, deltóides a largamente ovais, cartáceas ou membranáceas, glabras ou velutinas na face abaxial, esverdeadas, oliváceas a marrom-escuras, 7-9 nervuras salientes em ambas as faces, $3,5-12 \mathrm{~cm}$ compr.; pecíolos robustos, comprimidos, canaliculados, glabros, $0,5-5 \mathrm{~cm}$ compr. Inflorescências estaminadas em espigas, compondo panículas simples, glabras e pilosas, $4-12 \mathrm{~cm}$ compr., flores isoladas em cada nó; bráctea oblongocaudada, 3-4mm compr., pilosa, com pontuações avermelhado-escuras; profilo oblongo-apiculado, 2-2,5mm compr., piloso, com pontuações escuras; flores com perianto campanulado ou rotáceo, esverdeado ou amarelado; tépalas internas e externas oblongo-acuminadas ou apiculadas, 1,5-2mm compr.; estames 3 , inseridos alternadamente na base das tépalas; anteras ca. $0,3 \mathrm{~mm}$ compr., lateral-introrsas, oval-alongadas, globosas, conectivo largo, unindo as anteras, deiscência longitudinal, filetes ca. $0,6 \mathrm{~mm}$ compr., filiformes, achatados na base, depois cilíndricos; estaminódios 3, alternados com os estames, filiformes, lanceolados; pistilódio, quando presente, tripartido desde a base, com 3 estilódios lanceolados com ca. $0,7 \mathrm{~mm}$ compr. Inflorescências pistiladas em racemos, pêndulas, $10-50 \mathrm{~cm}$ compr.; flores com perianto rotáceo a campanulado, amarelado, alaranjado a castanho-escuro, isoladas em cada nó floral, com pedicelo curto, bráctea e profilo ca. 1 $\mathrm{mm}$ de comprimento, ambos com as margens serradas; tépalas internas e externas oblongo-acuminadas, $1,5-2 \mathrm{~mm}$ compr.; gineceu tricarpelar, colunar, grosso, estiletes soldados na base, tripartido no ápice, ramos bífidos, globosos; estaminódios 6 , amarelados, sésseis ou curtamente pedicelados, ovais, ca. $0,8 \mathrm{~mm}$ compr. Cápsulas 1-2,1 cm compr., circulares, obovadas ou largamente depresso-ovais, com valvas amareladas, apiculadas, com pontuações avermelhadas esparsas, margens levemente dilatadas. Sementes ca. $1,1 \mathrm{~cm}$ compr., circulares, amareladas ou alaranjado-escuras, com ala circular, estreitada próximo à sua inserção na soldadura das valvas.

Material examinado: Minas Gerais: Grão Mogol, 13.IV. 1981, I. Cordeiro et al. 839a, fl. masc. (SP, SPF); Grão Mogol, 13.IV.1981, I. Cordeiro et al. 839b, fl. fem., fr. (SP, SPF).

Distribuição geográfica e hábitats: D. rumicoides é uma espécie rara, com distribuição neotropical e exclusiva no Brasil; na Cadeia do Espinhaço foi coletada apenas em Grão Mogol, em campo rupestre, em ambiente aberto e ensolarado, com solo pedregoso, raso, bem drenado e de baixa fertilidade.

Dioscorea rumicoides ocorre no interior de florestas pluviais (Mata Atlântica), florestas de galeria e em áreas abertas nos campos rupestres. Distribui-se pelos estados de Goiás, Minas Gerais e do Rio de Janeiro até Santa Catarina. Ocorre, ainda, na Bolívia e no Peru.

21. Dioscorea scabra Humb. \& Bonpl. in Willd., Sp. pl., ed. 4, p. 794. 1805. 


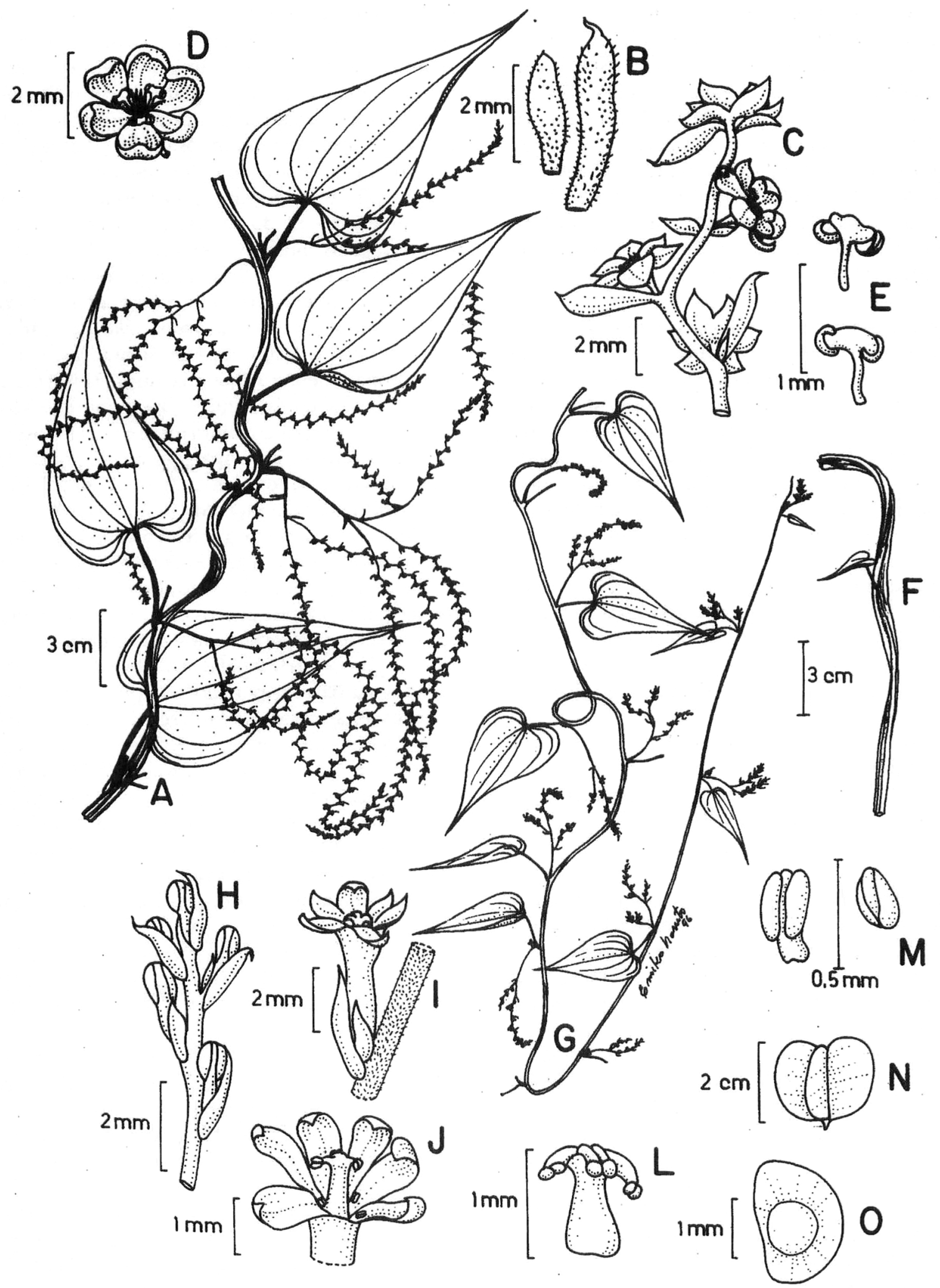

Fig. 21: Dioscorea rumicoides Griseb. A. ramo florífero (planta masculina); B-E. flor estaminada; B. bráctea (menor) e profilo apiculado; C. flores em antese, brácteas e profilos; D. perigônio, estames e pistilódio; E. estames; F. seção do ramo e folha jovem; G. ramo florífero; H-M. flor pistilada; H. flores jovens e brácteas; I. flor em antese, bráctea e profiro; J. perigônio, estaminódio, estilete e estigma; L. estilete e estigma; M. estaminódios; N. cápsula; O. semente. (A-E: Cordeiro et al. 839a; F-O: Cordeiro et al. 839b) 
Tipo: Venezuela, "rio Orinoco, Ilha Pararuma", Humboldt 864 in herb. Willd. 18417, planta masculina (Holótipo B!).

Fig. 22

Plantas dióicas. Sistema subterrâneo constituído por um rizóforo quase superficial, com tuberosidades achatadas ou piramidais, irregulares quando mais profundas, lenhosas quando mais velhas, nodosas, de onde partem numerosas raízes longas (ca. 2,5m compr.), fibrosas, esbranquiçadas, intumescidas em vários pontos; periderme marrom-acinzentada e medula brancoamarelada. Lianas com ramos perenes, amarelados, esverdeados ou castanho-escuros, dextrogiros, eretos ou apoiantes, $10 \mathrm{~cm}-4 \mathrm{~m}$ compr., glabros ou pilosos, estriados, 1-3,1mm diâm. Caules jovens em seção transversal circulares, quando mais velhos quase circulares, elípticos, canaliculados, com espinhos desde a base até ca. 1 $\mathrm{m}$ compr. Folhas alternas ou opostas, oblongo-lanceoladas a cordado-hastadas, cartáceas, glabras, esverdeadas, amareladas a alaranjado-escuras, com nervuras salientes na face abaxial, $5-13 \mathrm{~cm}$ compr.; pecíolos robustos, estriados, glabros, $2-6 \mathrm{~cm}$ compr. Inflorescências estaminadas racemosas, $5-16 \mathrm{~cm}$ compr., flores 1-3 por nó floral; bráctea oblongo-acuminada, 2,2-2,5mm compr.; profilo obovado, ca. $3 \mathrm{~mm}$ compr.; perianto campanulado, amarelo-esverdeado; tépalas internas e externas elíptico-lanceoladas, 1-1,2mm compr.; estames 6 , inseridos a $1 / 3$ da base das tépalas; anteras ca. 0,2 mm compr., introrsas, ovaladas a elípticas, deiscência longitudinal, filetes ca. $0,8 \mathrm{~mm}$ compr., cilíndricos, levemente curvados na base; pistilódio pequeno, cônico, com três sulcos longitudinais, ca. $0,2 \mathrm{~mm}$ compr. Inflorescências pistiladas em espigas, levemente pêndulas, $6-14 \mathrm{~cm}$ compr.; flores com perianto campanulado, amarelado, alaranjado a castanho-escuro, isoladas em cada nó floral, sésseis, com bráctea e profilo oblongo-lanceolados, 1,3-1,8mm compr. Tépalas internas e externas oblongo-acuminadas, 1,2-1,5mm compr.; gineceu tricarpelar, estiletes unidos na base, breves, crassos, tripartidos no ápice, ramos bífidos, globosos; estaminódios 6 , hialinos a amarelados, subsésseis ou pedicelados, quadrangulares, clavado-capitados, ca. $0,5 \mathrm{~mm}$ compr., com pontuações avermelhadas. Cápsulas 1,5$2,5 \mathrm{~cm}$ compr., obovadas a arredondadas, glabras, valvas amareladas, cartáceas, margens levemente engrossadas. Semente ca. $5 \mathrm{~mm}$ compr., elíptica, central, escura, brilhante, com asa circular amarelo-escura.

Material examinado: Minas Gerais: Ouro Preto, Tripuí, 25.VIII.1896, Schwacke 12434, fl. masc. (RB); Belo Horizonte, Caetano Furquim, 17.I.1933, H. Mello Barreto 2400a, fr. (R); Belo Horizonte, Jardim Botânico, 1933, H. Mello Barreto 2403, fl. masc. (RB); Belo Horizonte, Jardim Botânico,
22.V.1934, H. Mello Barreto 2407, fl. masc. (BHMH, R); Belo Horizonte, 29.V.1934, H. Mello Barreto 2408, fl. fem., fr. (BHMH, R); Nova Lima, 29.III.1942, M. Magalhães 1492, fl. fem. (RB); Ouro Preto, 1942, M. Magalhães 1203, fr. (BHMH, RB); Grão Mogol, 21.II.1969, H.S. Irwin et al. 23663, fl. masc. (UB); Ouro Preto, Estação Ecológica do Tripuí, 16.XI.1978, J.J. Badini s.n., fl. masc. (UFOP); Corinto, margem esquerda do rio Bicudo, 28.VII.1986, G. Pedralli E Silva 2665 (CEN); Caeté, Serra da Piedade, 15.VII.1987, Paula et al. 18541, fl. masc. (BHCB); Nova Lima, IX.1987, J. Slehmann et al. 10591, fl. masc. (BHCB); Santana do Riacho, 24.V.1989, Perez et al. 18768 (BHCB); Santana do Riacho, Serra do Cipó, Morro da Pedreira, 24.V.1989, J. Stehmann et al. 18768, fl. masc. (BHCB); Ouro Preto, Estação Ecológica do Tripuí, 5.V.1992, G. Pedralli s.n., fr. (HXBH); Ouro Preto, Estação Ecológica do Tripuí, 30.I.1993, G. Pedralli 3384, fl. masc. (HXBH); Tiradentes, Área de Proteção Ambiental da Serra de São José, 6.II.1993, G. Pedralli 3386 (HXBH); Tiradentes, Caminho da Estrada Real, 7.II.1993, G. Pedralli 3387, fl. masc. (HXBH); Caçaratiba, 18.II.1993, G. Pedralli 3389, fl. masc. (HXBH); Ouro Preto, Estação Ecológica do Tripuí, 3.VII.1993, G. Pedralli s.n. (HXBH); Ouro Preto, Estação Ecológica do Tripuí, apiário, 3.IX.1993, Teixeira $\mathcal{E}$ Oliveira s.n. $(\mathrm{HXBH})$; Ouro Preto, Estação Ecológica do Tripuí, córrego Tripuí, 3.IX.1993, Teixeira E Oliveira s.n., fl. masc. (HXBH); Ouro Preto, Tripuí, 3.IX.1993, Teixeira $\mathfrak{E}$ Oliveira s.n., fr. (HXBH); Ouro Preto, Estação Ecológica do Tripuí, Pontilhão, 3.IX.1993, Teixeira Ev Oliveira s.n. (HXBH); Moeda, rio Paraopeba, 20.IX.1993, G. Pedralli s.n. (HXBH); Belo Vale, cachoeira na Serra de Ouro Branco, 20.IX.1993, G. Pedralli s.n., fr. (HXBH); Ouro Preto, ponte na estrada para São Bartolomeu, km 8, 21.IX.1993, G. Pedralli s.n. (HXBH); Ouro Branco, estrada para Saramenha, 21.IX. 1993, G. Pedralli s.n. (HXBH); Ouro Branco, Serra de Ouro Branco, 21.IX.1993, G. Pedralli s.n. (HXBH); Ouro Preto, Estação Ecológica do Tripuí, 14.X.1993, Oliveira s.n., fl. masc. (HXBH); Ouro Preto Estação Ecológica do Tripuí, córrego do Apiário, 16.X.1993, Teixeira et al. s.n., fl. masc. (HXBH); Ouro Preto, Estação Ecológica do Tripuí, 20.X. 1993, Teixeira et al. s.n., fl. masc. (HXBH); Ouro Preto, Estação Ecológica do Tripuí, pontilhão, 9.XI.1993, Teixeira $\mathfrak{E}$ Oliveira s.n. (HXBH); Ouro Preto, estrada para São Bartolomeu, córrego no km 8, 9.XI.1993, Teixeira E Oliveira s.n., fl. masc. (HXBH); Ouro Preto, Estação Ecológica do Tripuí, 9.XI. 1993, Teixeira E Oliveira s.n. (HXBH); Ouro Preto, km 6 da estrada para São Bartolomeu, 11.XI.1993, Teixeira É Oliveieira s.n. (HXBH); Várzea da Palma, Serra do Cabral, 23. XI.1993, G. Pedralli 3424 (HXBH); Várzea da Palma, 23.XI.1993, G. Pedralli E Teixeira 3423 (HXBH); Santo Hipólito, km 4 da estrada para Monjolos, 24.XI.1993, G. Pedralli Ev Teixeira 3440 (HXBH); Conceição do Mato Dentro a $2 \mathrm{~km}$ do trevo para Morro do Pilar, 26.XI.1993, G. Pedralli E Teixeira 3447, fl. masc. (HXBH); Ouro Preto, Estação Ecológica do Tripuí, córrego Tripuí, 13.IV.1994, Tei- 


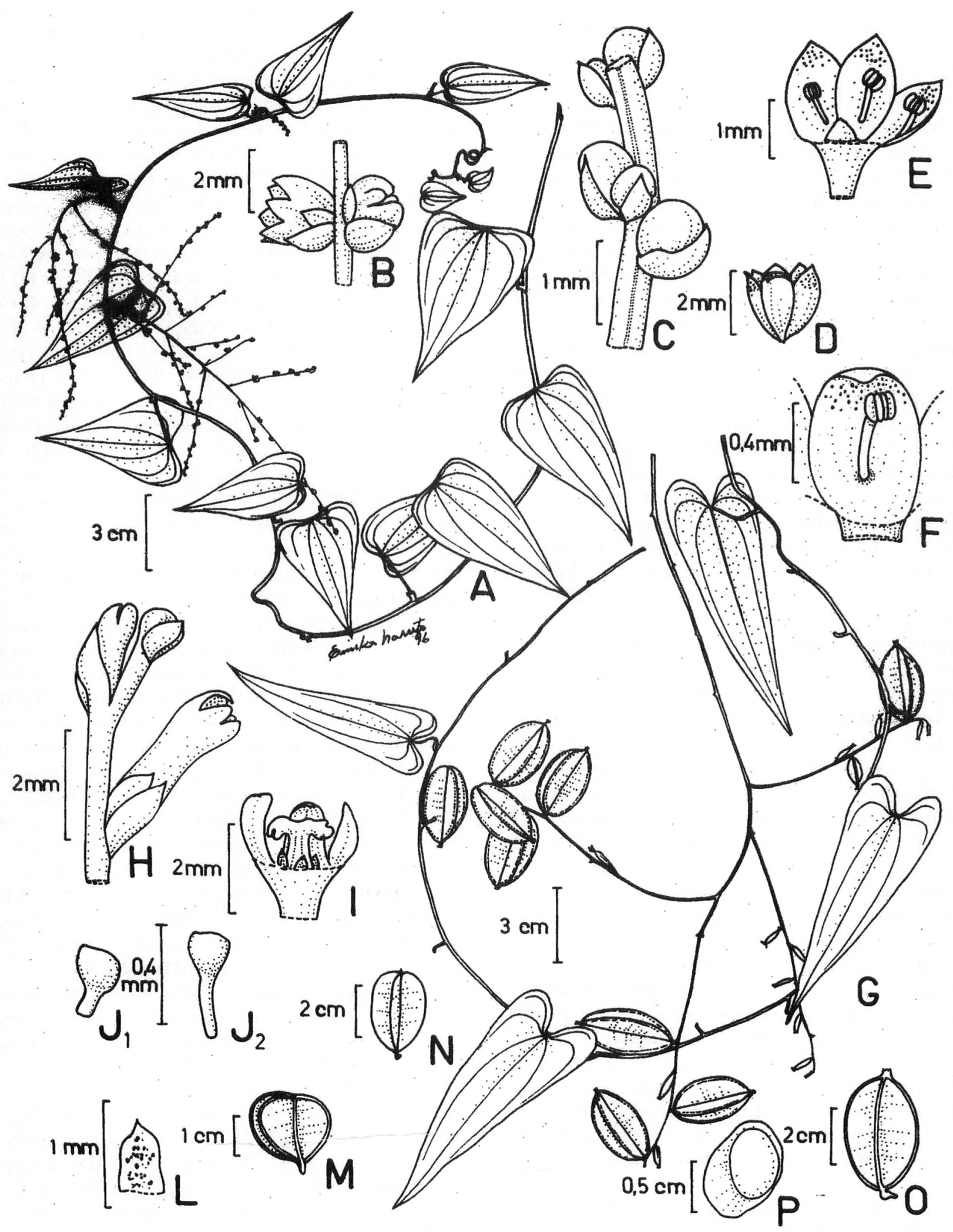

Fig. 22: Dioscorea scabra Humb. \& Bonpl. A. ramo florífero (planta masculina); B-F. flor estaminada; B. flores em antese, brácteas e profilos; C. flores jovens, brácteas e profilos; D. flor em antese; E. tépalas, estames e pistilódio; F. tépala e estame; G. ramo florífero (planta feminina); H-L. flor pistilada; H. flores jovens, brácteas e profilos; I. perigônio, estaminódios, estilete e estigma; J1-J2. estaminódios pedicelados; L. estaminódio séssil; M-O. cápsulas; P. semente. (A-F: Pedralli Eं Teixeira 3447; G-P: Pedralli Eْ Teixeira s.n.) 
xeira E' Santos s.n., fl. masc. (HXBH); Ouro Preto, Estação Ecológica do Tripuí, segundo córrego após o apiário, 19.IV.1994, G. Pedralli Ẽ Teixeira s.n (HXBH); Ouro Preto, Estação Ecológica do Tripuí, 19.IV.1994, G. Pedralli Ẽ Teixeira s.n._(HXBH); Ouro Preto, Estação Ecológica do Tripuí, à esquerda do pontilhão, 19.IV.1994, G. Pedralli $\mathcal{E}$ Teixeira s.n., fl. fem., fr. (HXBH); Ouro Preto, córrego São Bartolomeu, 21.VI.1994, G. Pedralli E Teixeira s.n. (HXBH); Betim, estrada Citrolândia-Serra das Bandeirinhas, 23.VI.1994, G. Pedralli s.n. (HXBH); Ouro Preto, Estação Ecológica do Tripuí, apiário, 16.II.1995, Teixeira et al. s.n., fl. fem., fr. (HXBH); Ouro Preto, Estação Ecológica do Tripuí, apiário, 16.II.1995, Teixeira et al. s.n., fl. masc. (HXBH); sem local, 1845, Regnell 11279 (R); Belo Horizonte, Jardim Botânico, sem data, Sampaio 7417, fr. (R); sem local, 23.VIII.1964, H.S. Irwin Ẽ T. Soderstrom 5463 (UB); Sabará, [em floresta], sem data, Richard 968, fl. masc. (P); Lagoa Santa, sem data, Warming s.n., fl. masc. (P).

Distribuição geográfica e hábitats: a espécie apresenta distribuição americano-africana, disjunta, e na Serra do Espinhaço é encontrada na orla das florestas de galeria e florestas mesófilas, nos cerrados típicos, em fendas dos af loramentos rochosos dos campos rupestres e em ambientes perturbados, após queimadas e desmatamentos.

Dioscorea scabra ocorre em todos os tipos de formações, florestais e campestres e em áreas perturbadas, como pioneira nas sucessões secundárias. Distribui-se desde o Amazonas, Ceará, Piauí, Mato Grosso, Mato Grosso do Sul, Goiás, Tocantins, Distrito Federal, Minas Gerais, Bahia e do Espírito Santo até o Rio Grande do Sul. Ocorre, ainda, nas ilhas do Caribe e da Venezuela até as florestas de galeria do sul do Paraguai e norte da Argentina e na África do Sul.

22. Dioscorea sincorensis R. Knuth, Notizbl. Bot. Gart. Mus. Berlin 7(65): 186. 1917.

Tipo: Brasil, "Staat Bahia, Serra do Sincorá, in Felsenschluchten”, [XI.1906], Ule 7303, planta masculina (Holótipo B n.v.; foto do holótipo B!; Isótipo K!).

Fig. 23

Plantas dióicas. Sistema subterrâneo constituído por um rizóforo curto (ca. $5 \mathrm{~mm}$ compr.), profundo, tuberosidades piramidais, irregulares, lenhosas, curtas (até 5 $\mathrm{cm}$ comprimento), às vezes globosa quando mais próximas da superfície do solo; raízes fasciculadas, delicadas, brotando do corpo central; periderme marrom-escura e medula branco-amarelada. Lianas com ramos perenes, esverdeados a castanho-escuros, sem expansões laterais, dextrogiros, eretos a apoiantes, glabros, 0,5-2m compr. e 1:1,5mm diâm. Caules jovens em seção transversal circulares, canaliculados, cobertos por tricomas glandulares, quando mais velhos elípticos, aplanados, glabros. Folhas simples, alternas, ovadas, cartáceas a coriáceas, glabras, esverdeadas a oliváceas, opacas na face abaxial, com 7 nervuras salientes em ambas as faces, $2-8 \mathrm{~cm}$ compr.; pecíolos robustos, canaliculados, amarelo-alaranjados, 1$2 \mathrm{~cm}$ compr. Inflorescências estaminadas em espigas, 4$20 \mathrm{~cm}$ compr., 3-8 flores por nó floral, sésseis ou pediceladas; bráctea ovado-acuminada, ca. 1,2mm compr.; profilo linear-lanceolado, ca. $1 \mathrm{~mm}$ compr.; flores com perianto campanulado, amarelado, esverdeado, alaranjado a castanho-escuro, piloso, com pontuações avermelhadas no terço inferior; tépalas externas e internas ovado-oblongas, 1-1,5mm compr.; estames 6 , soldados na base, formando um círculo em redor do pistilódio; anteras ca. $0,03 \mathrm{~mm}$ compr., introrsas, obovadas, deiscência longitudinal, filetes $0,5-0,8 \mathrm{~mm}$ compr., filiformes, cilíndricos; pistilódio cônico-triangular, ca. 0,02mm compr., íntegro, amarelado a alaranjado. Inflorescências pistiladas em espigas, pêndulas, $4-8 \mathrm{~cm}$ compr.; flores com perianto campanulado, amarelado a alaranjado-escuro, isoladas em cada nó floral, sésseis; bráctea oblongo-lanceolada, ca. 1,2mm compr.; profilo com a mesma for$\mathrm{ma}$, ca. $1 \mathrm{~mm}$ compr.; tépalas internas e externas oblongo-acuminadas, 1-1,2 $\mathrm{mm}$ compr.; gineceu tricarpelar, colunar, tripartido no ápice, ramos simples, amarelados, 6 estaminódios, branco-amarelados, capitados, ca. 0,01 mm compr. Cápsulas 1-2,2cm compr., elípticas, valvas alaranjadas a castanho-escuras, com margens estreitamente dilatadas e restos do perigônio no ápice. Sementes ca. $2 \mathrm{~mm}$ compr., oval-elípticas, castanho-escuras, com ala circular expandida para o ápice, alaranjada.

Material examinado: Bahia: Serra do Sincorá, XI.1906, Ule. 7303, fl. masc. (B, K); Rio de Contas, Pico das Almas, 23. I.1974, R.M. Harley 15442, fl. masc. (K, P, CEPEC); Mucujê, $22 \mathrm{~km}$ ao sul de Andaraí, 12.II.1977, R.M. Harley 18779, fl. masc. (UEC, RB, K); Mucujê, $22 \mathrm{~km}$ ao sul de Andaraí, 16.II.1977, R.M. Harley 18779, fl. masc. (RB); Morro do Chapéu, rio do Ferro Doido, 1.III.1977, R.M. Harley 19194, fl. masc. (CEPEC, K); Mucujê, 25.I.1980, R.M. Harley et al. 20582, fl. masc. (CEPEC, K); Boninal, Chapada de Boninal, 21.III. 1980, Pinto 145, fl. masc. (HRB); Barra da Estiva, Serra do Sincorá, 24.III.1980, R.M. Harley et al. 20898, fl. masc. (RB, K); $6,5 \mathrm{~km}$ a sudoeste de Mucujê, Serra do Sincorá, 27.III. 1980, R.M. Harley 21031, p.p., fl. masc. (RB, K); 6,5km a sudoeste de Mucujê, Serra do Sincorá, 27.III.1980, R.M. Har ley 21031, p.p., fr. (RB, K); Palmeiras, Serra dos Lençóis, 24. V.1980, R.M. Harley 22522, fl. masc. (RB, K); Lençóis, Caeté-Açu, Serra da Lagoinha, 25.V.1980, R.M. Harley 22589, fl. masc. (CEPEC, K); Morro do Chapéu, 30.V.80, R.M. Harley 22827, pl. masc. (CEPEC, K); $6 \mathrm{~km}$ a leste de Morro do Chapéu, 18. VI.1981, S. Mori E̋ Boom s.n., fr. (CEPEC); km 7 da estrada Maracás-Contendas do Sincorá, 9.II.1983, A. Carvalho E T. Plowman 1574, fl. masc. (CEPEC); Lençóis, 


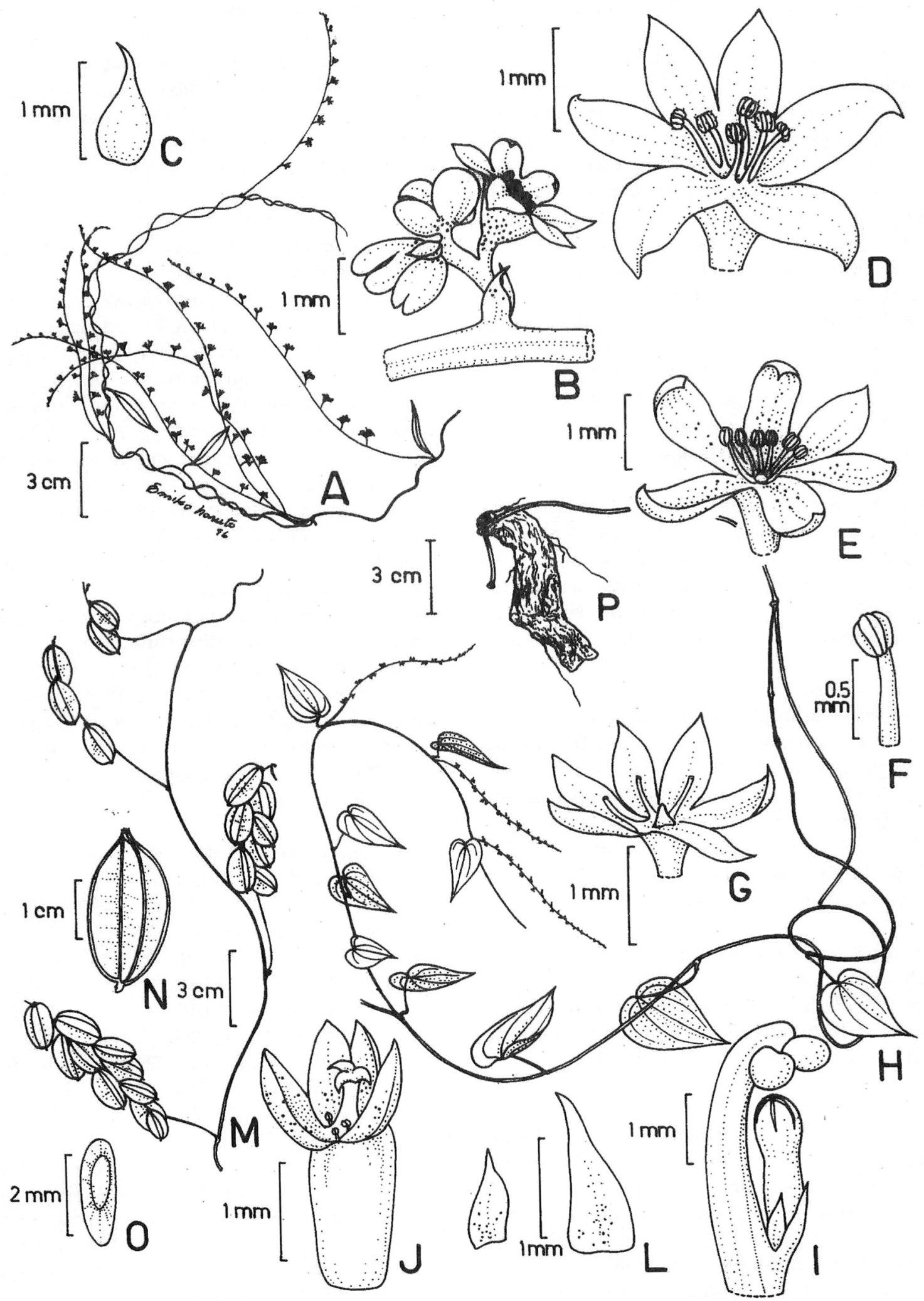

Fig. 23: Dioscorea sincorensis R. Knuth. A. ramo florífero (planta masculina); B-G. flor estaminada; B. flores em antese, bráctea e profilo; C. bráctea; D. perigônio e estames; E. perigônio, estames e pistilódio; F. estame; G. perigônio e pistilódio; H. ramo florífero (planta feminina); I-L. flor pistilada; I. flores jovens, bráctea e profilo; J. perigônio, estaminódios, estilete e estigma; L. bráctea (maior) e profilo; M. ramo em frutificação; N. cápsula; O. semente. (A-G: Pedralli 3390; H-O: Vieira et al. 118) 
28.VI.1983, M.L. Guedes 655, fr. (ALCB, HRB); Lençóis, 28.VI.1983, L.P. Queiroz 602 (HXBH, HUEFS); Lençóis, 5.VII.1983, L. Coradin et al. 6540 (CEN); Rio de Contas, Pico das Almas, 14.XII.1984, B. Stannard et al. 6878, fl. masc. (K, SPF); Lençóis, oeste de Serra Larga, 19.XII.1984, G. Lewis et al. 7230, fr. (SPF, K); Piatã, 14.II.1987, R.M. Harley et al. 24178 , fl. masc. (SPF, K); a $7 \mathrm{~km}$ de Buenópolis, Serra do Cabral, 12.X.1988, R.M. Harley et al. 24886, fl. masc. (K, SPF); Rio de Contas, Pico das Almas, campo do Queiroz, vertente leste, 29.XI.1988, R.M. Harley et al. 26665, fl. masc. (SPF); Rio de Contas, Pico das Almas, 11.XII.1988, R.M. Harley et al. 27108, fl. masc. (SPF, K); Rio de Contas, Pico das Almas, 11.XII.1988, R.M. Harley et al. 27109 (SPF, K); Rio de Contas, Pico das Almas, Água Quente, 17.XII.1988, R.M. Harley et al. 27548, fl. masc. (SPF, K); a $2 \mathrm{~km}$ de Juramento, 14.XII.1989, J.R. Pirani et al. 12799, fl. masc. (SPF); Abaíra, serra ao sul do riacho da Taquara, 10.I.1992, R.M. Harley $\dot{\sigma}^{\circ}$ A. Fierro 51265, fl. fem. (K, SPF, CEPEC, HUEFS); Abaíra, Campo de Ouro Fino, 10.I.1992, R.M. Harley et al. 50740, fl. masc. (K, SPF, CEPEC, HUEFS); Abaíra, Campo de Ouro Fino, 25.I.1992, B.L. Stannard et al. 50800, fl. masc. (SPF, CEPEC, HUEFS, K); Abaíra, Campo do Cigano, 28.I.1992, B.L. Stannard et al. 50826, fl. masc. (SPF, CEPEC, HUEFS, K); Abaíra, Campo do Cigano, 28.I. 1992, B.L. Stannard, J.R. Pirani et al. 50826, fl. masc. (K, SPF, CEPEC, HUEFS); Abaíra, encosta da Serra do Tromba, 2.II. 1992,J.R. Pirani et al. 31500 , fl. masc. (K, SPF, CEPEC, HUEFS); Abaíra, Campo do Cigano, 5.II.1992, B.L. Stannard et al. 51182, fl. masc. (K, SPF, CEPEC, HUEFS); Abaíra, Serra da Água Branca, 07.II.1992, B.L. Stannard EF R. Queiroz 51067, fl. masc. (K, SPF, CEPEC, HUEFS); Lençóis, 23.II. 1993, G. Pedralli 3399 (HXBH); Lençóis, 23.II.1993, G. Pedralli 3398, fl. masc. (HXBH); Abaíra, Campo do Cigano, 26.II.1992, P.T. Sano E T. Laessoe 52339 , fl. masc. (K, SPF, CEPEC, HUEFS); Abaíra, estrada CatolésRibeirão de Baixo-Inúbia, 19.III.1992, B.L. Stannard $\mathcal{E}$ T.R. Silva 52702, fl. masc. (K, SPF, CEPEC, HUEFS); Abaíra, Garimpo do Bicota, 24.III.1992, B.L. Stannard Ẽ T.R. Silva 52810, fl. masc. (K, SPF, CEPEC, HUEFS); Abaíra, Bicota, 21.XII.1993, W. Ganev 2670, fl. masc. (HUEFS); Abaíra, Campos do Virassaia, 30.XII.1993, W. Ganev 2721, fl. fem., fr. (HUEFS); Abaíra, Campos do Virassaia, 30.XII.1993, W. Ga nev 2733, p.p., fl. masc. (HUEFS); Abaíra, Campos do Virassaia, 30.XII.1993, W. Ganev 2733, p.p., fl. fem., fr. (HUEFS); Abaíra, Riacho do Piçarrão de Osmar Campos, 8.V.1994, W. Ganev 3228, fl. fem., fr. (HUEFS); Lençóis, Serra da Chapadinha, próximo ao riacho Mucugezinho, 5.VII.1994, M.L. Guedes et al. 036, fl. fem., fr. (SPF, K, ALCB); Palmeiras, Pai Inácio, 30.VIII. 1994, M.L. Guedes et al. 587, fr. (ALCB); Lençóis, Serra da Chapadinha, 5.II.1995, A.M. Giulietti $\mathcal{E}$ L. Funch 1564, fl. masc. (ALCB); Serra da Chapadinha, Chapadinha, Lençóis, 24.II.1995, E. Melo, F. França Ẽ M. Serra 1740, fl. masc. (SPF, K. ALCB); Lençóis, Serra da Chapadinha, 30.VI.1995, M.L. Guedes et al. 2060, fr. (ALCB). Minas Gerais: Santo Antônio do Itambé, descida do pico do Itambé,
6.IV.1982, L. Rossi et al. 3090, fl. masc. (SPF); ao norte de Grão Mogol, 27.I.1984, R.M. Harley et al. 6496, fl. masc. (SPF, K); Ouro Preto, Cachoeira das Andorinhas, 9.1I.1985, Vieira et al. 118, fl. fem., fr. (VIC); Buenópolis, Serra do Cabral, 12.X.1988, R.M. Harley et al. 24886, fl. masc. (SPF); Caçarandiba, 18.II.1993, G. Pedralli 3390, fl. masc. (HXBH); Ouro Preto, APA da Cachoeira das Andorinhas, 10.XI.1993, Teixeira EN Oliveira s.n. (HXBH); Joaquim Felício, Serra do Cabral, 24.XI.1993, G. Pedralli E $\mathcal{F}^{2}$ Teixeira 3437, fl. fem., fr. (HXBH); sem local, sem data, Damazio 1587 (RB).

Distribuição geográfica e hábitats: Dioscorea sincorensis apresenta distribuição neotropical e exclusiva no Brasil. Na Serra do Espinhaço ocorre em áreas abertas nos campos rupestres, em solos arenosos, quartzíticos ou pedregosos, nos cerrados e em afloramentos rochosos, ou em fendas de rochas, onde esteja depositada uma camada mínima de solo. Distribui-se pelos estados do Mato Grosso, Goiás, Distrito Federal, Bahia e Minas Gerais. Na Bahia e em Minas Gerais ocorre somente na área dos campos rupestres.

23. Dioscorea sinuata Vell., Fl. flum. 10 (ícones): tab. 129. 1831, et in Archos. Mus. Nac. Rio de Janeiro 5: 426. 1881.

Tipo: Vellozo, Fl. flum. 10 (ícones): tab. 129. (Lectótipo).

Fig. 24

Plantas dióicas. Sistema subterrâneo constituído por um rizóforo curto (ca. $1,5 \mathrm{~cm}$ compr.), superficial a profundo; tuberosidades discóides, aplanadas, com $8-16 \mathrm{~cm}$ diâm., às vezes irregulares com lobos unilaterais, em várias camadas concêntricas; periderme lisa a reticulada, alaranjada a marrom-escura, medula branco-amarelada. Da base das tuberosidades brotam raízes pequenas, filiformes, ramificadas. Ponto vegetativo central ou na margem, oposto aos lobos. Liana com ramos perenes, amarelados, esverdeados a castanho-claros, sem expansões laterais, dextrogiros, sempre volúveis, 0,42,0m compr., glabros, estrigosos a hirsutos, 0,05-3mm diâm., quando mais velhos circulares, glabros a hirsutos, com expansões laterais ('alados'). Caules jovens em seção transversal poligonais, glabros, muricados ou hirsutos, com tricomas glandulares dispostos em fileiras nos ângulos. Folhas simples, opostas, polimorfas, ovais, acuminadas, cordadas a palmatilobadas; número de lobos variável, em geral 3-5; margem crenada, membranáceas, glabras ou muricadas nas nervuras, amarelo-esverdeadas, acinzentadas ou castanho-escuras, 7-11 nervuras salientes na face abaxial, 2,5-14cm compr., densamente muricadas na inserção nos ramos. Nectários extraflorais sob a forma de pontos escuros podem ocorrer entre as nervuras no terço inferior da lâmina, 


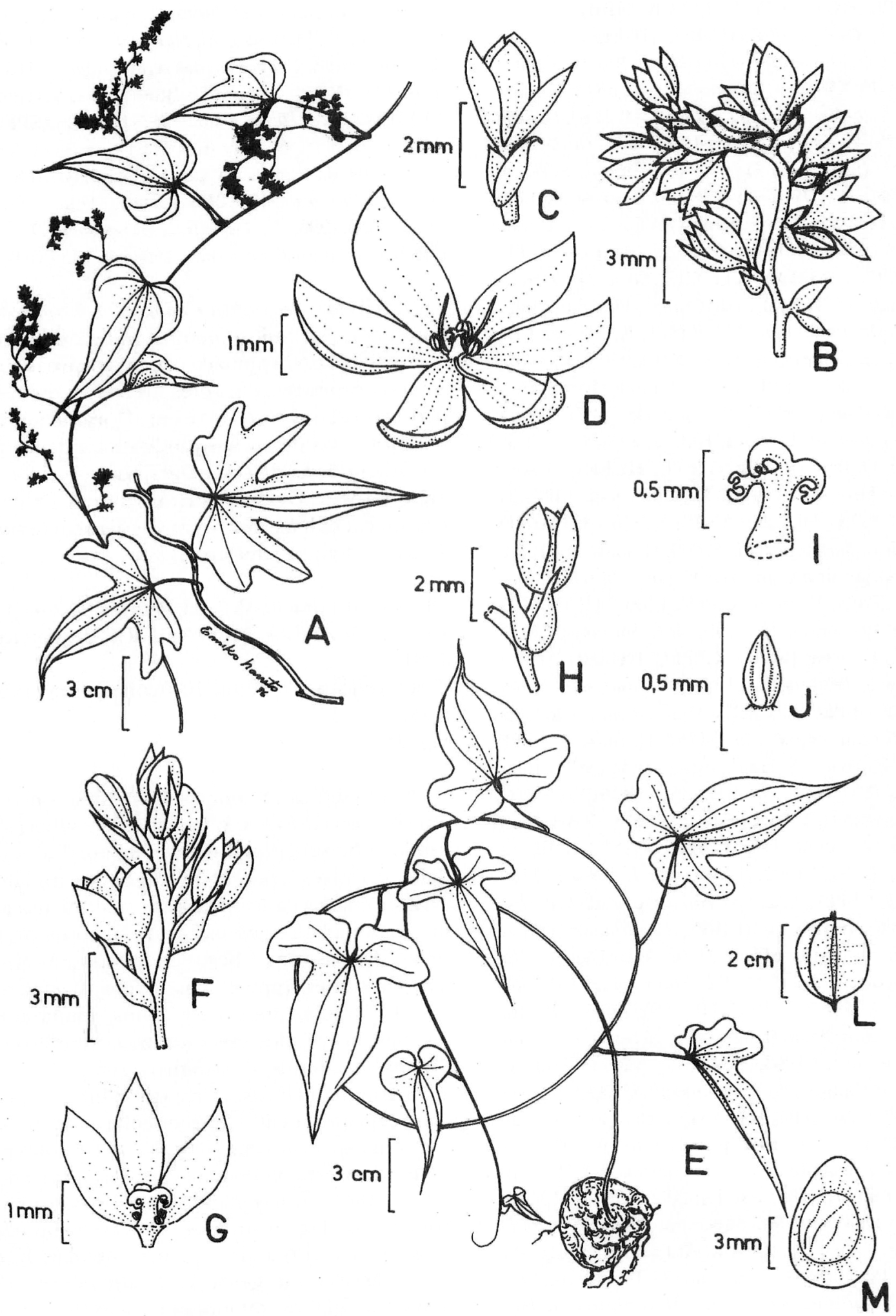

Fig. 24: Dioscorea sinuata Vell. A. ramo florífero (planta masculina); B-D. flor estaminada; B. flores em antese, brácteas e profilos; C. flor em antese, bráctea e profiro; D. perigônio, estames e estaminódios; E. ramo florífero (planta feminina); F-J. flor pistilada; F. flores em antese, brácteas e profilos; G. tépalas, estaminódios, estilete e estigma; H. flor jovem, bráctea e profilo; I. estilete e estigma; J. estaminódio; L. cápsula; M. semente. (A-D: Pedralli Ẽ Teixeira 3422; E-M: Pedralli E゚ Teixeira s.n.) 
próximos ao pecíolo. Inflorescências estaminadas em panículas multifloras, $2-20 \mathrm{~cm}$ compr., flores 3-5 por nó floral; bráctea e profilo elíptico-ovais, caudados a acuminados, 1,5-2mm compr.; flores com perianto campanulado, alvo-esverdeado; tépalas internas e externas ovado-elípticas, 2-3mm compr.; estames 3, alternos com 3 estaminódios, inseridos em redor do pistilódio; anteras ca. $0,2 \mathrm{~mm}$ compr., introrsas, elíptico-oblongas, deiscência longitudinal, filetes curtos, menores que as anteras, cilíndricos; estaminódios 3, linear-lanceolados, alvo-amarelados, ca. $1 \mathrm{~mm}$ compr., mais longos que os estames; pistilódio cilíndrico, base alargada, ca. $0,8 \mathrm{~mm}$ compr., estilódios 3, com ramos bífidos, curvados para o exterior. Inflorescências pistiladas em espigas simples, pêndulas, $2-15 \mathrm{~cm}$ compr.; flores com perianto campanulado, alvo-amarelado, isoladas em cada nó floral, sésseis ou com pedicelo curto; bráctea e profilo ovado-acuminados, $2-2,5 \mathrm{~mm}$ compr. Tépalas internas e externas elíptico-oblongas, acuminadas, $2,1-3 \mathrm{~mm}$ compr.; gineceu tricarpelar, colunar, breve, ca. $0,5 \mathrm{~mm}$ compr., grosso, cilíndrico, tripartido no ápice, ramos bífidos, capitados; estaminódios 3, alvo-amarelados, sésseis, estreitamente elípticos, ca. 0,3mm compr. Cápsulas 1-2 cm compr., largamente elípticas, transversalmente elíptica ou largamente depresso-ovada, valvas esverdeadas (ao vivo) ou alaranjadas a castanho-escuras, ápice obtuso, margens levemente dilatadas. Sementes ca. $8 \mathrm{~mm}$ compr., circulares, lisas, amarelo-alaranjadas, com asa circular prolongada em direção ao ápice.

Material examinado: Minas Gerais: Ouro Preto, próximo à ponte na estrada para São Bartolomeu, 21.IX.1993, G. Pedralli 3411 , fl. masc. (HXBH); Ouro Preto, $\mathrm{km} \mathrm{8}$, estrada para São Bartolomeu, 11.XI.1993, Teixeira E Oliveira s.n., fl. masc. (HXBH); Várzea da Palma, vertente oeste da Serra do Cabral, 23.XI.1993, G. Pedralli E Teixeira 3422, fl. masc. (HXBH); Ouro Preto, córrego São Bartolomeu, estrada para o distrito, 21.VI.1994, G. Pedralli $\mathcal{E} \mathcal{O}$ Teixeira s.n., fl. fem. (HXBH); Ouro Preto, córrego São Bartolomeu, 21.VI.1994, G. Pedralli E Teixeira s.n., fl. masc. (HXBH); Ouro Preto, margem esquerda do córrego São Bartolomeu, a $50 \mathrm{~m}$ da ponte, 21.VI.1994, G. Pedralli E Teixeira s.n., fl. masc. (HXBH); Lagoa Santa, sem data, Damazio s.n., fl. masc. (RB, OUPR).

Distribuição geográfica e hábitats: Dioscorea sinuata é encontrada na beira e interior de florestas pluviais, em florestas de galeria, cerrados e restingas do sudeste do Brasil. Apresenta distribuição neotropical, nas Américas Central (Costa Rica) e do Sul, na Bolívia, Brasil, Chile, Paraguai, Argentina e Uruguai. No Brasil distribui-se pelos estados de Pernambuco, Distrito Federal, Goiás, Minas Gerais e da Bahia até o Rio Grande do Sul. Na Serra do Espinhaço ocorre em florestas de ga- leria, em locais sombreados em solos aluvionais, férteis, bem drenados e nos cerrados, nas áreas limítrofes dos campos rupestres em solos argilosos ou arenosos.

24. Dioscorea spicata (Vell.) G. Pedralli, comb. nov. Smilax spicata Vell., Fl. flum. 10 (ícones): tab. 112. 1831, et in Archos. Mus. Nac. Rio de Janeiro 5: 423. 1881. Tipo: Vellozo, Fl. flum. 10 (ícones): tab. 112 (Lectótipo).

Fig. 25

Plantas dióicas. Sistema subterrâneo constituído por um rizóforo superficial a profundo, curto; tuberosidades alongadas, cilíndricas a irregulares, com $10-20 \mathrm{~cm}$ compr., raízes amareladas a marrom-escuras, ramificadas, brotando da base; periderme amarelada, delgada e medula branca. Lianas com ramos perenes, esverdeados, amarelados a castanho-escuros, sem expansões laterais, sinistrogiros, $0,3-3 \mathrm{~m}$ compr., glabros, ca. $0,1 \mathrm{~cm}$ diâm. Ramos jovens pilosos na inserção das folhas, filiformes, em seção transversal circular-elípticos, comprimidos, quando mais velhos circulares, canaliculados. Folhas simples, alternas, simples ou compostas trifolioladas; as simples deltóides a ovadas, cordadas, acuminadas, $2,5-20 \mathrm{~cm}$ compr., membranáceas, glabras, 7 nervuras salientes em ambas as faces; pecíolos delicados, filiformes, ca. $1 \mathrm{~cm}$ compr. Folhas compostas trifolioladas com folíolos sésseis, elípticos a linear-lanceolados, $1-9 \mathrm{~cm}$ compr., glabros ou pilosos na inserção no caule e ao longo das três nervuras principais, 5 nervuras evidentes em ambas as faces; pecíolos com 1-1,5cm compr., triangulares em seção transversal, canaliculados, retorcidos na base. Inflorescências estaminadas racemosas, $4-15 \mathrm{~cm}$ compr., pêndulas ou apoiantes; flores 1-3 por nó floral, aglomeradas; bráctea ovado-acuminada na base, 1,2-1,6mm compr., com pontuações avermelhadas distribuídas longitudinalmente em relação ao eixo central; flores com perianto rotáceo, amarelado a alaranjado, escuro no centro do disco; tépalas internas e externas ovado-oblongas, 1-1,5mm compr., com pontuações avermelhadas no terço superior; estames 6 , sésseis ou subsésseis, inseridos na base das tépalas; anteras ca. $0,3 \mathrm{~mm}$ compr., branco-amareladas, arredondadas a oblongo-ovadas, introrsas, deiscência longitudinal; pistilódio pequeno, crasso, cônico, $0,2-0,5 \mathrm{~mm}$ compr., com 3 sulcos longitudinais desde a base, segmentos papilosos, amarelo-escuros. Inflorescências pistiladas em espigas, pêndulas, $6-12 \mathrm{~cm}$ compr.; bráctea linear-lanceolada, apiculada, ca. 0,3 mm compr.; flores com perianto campanulado, castanho-escuro; tépalas internas e externas ovadas a obovadas, 0,9-1,2 mm compr.; gineceu tricarpelar, crasso, colunar, estiletes 3 unidos, livres no terço superior, ramos bífidos, simples, escuros; estaminódios 6, inseridos na base do disco, 


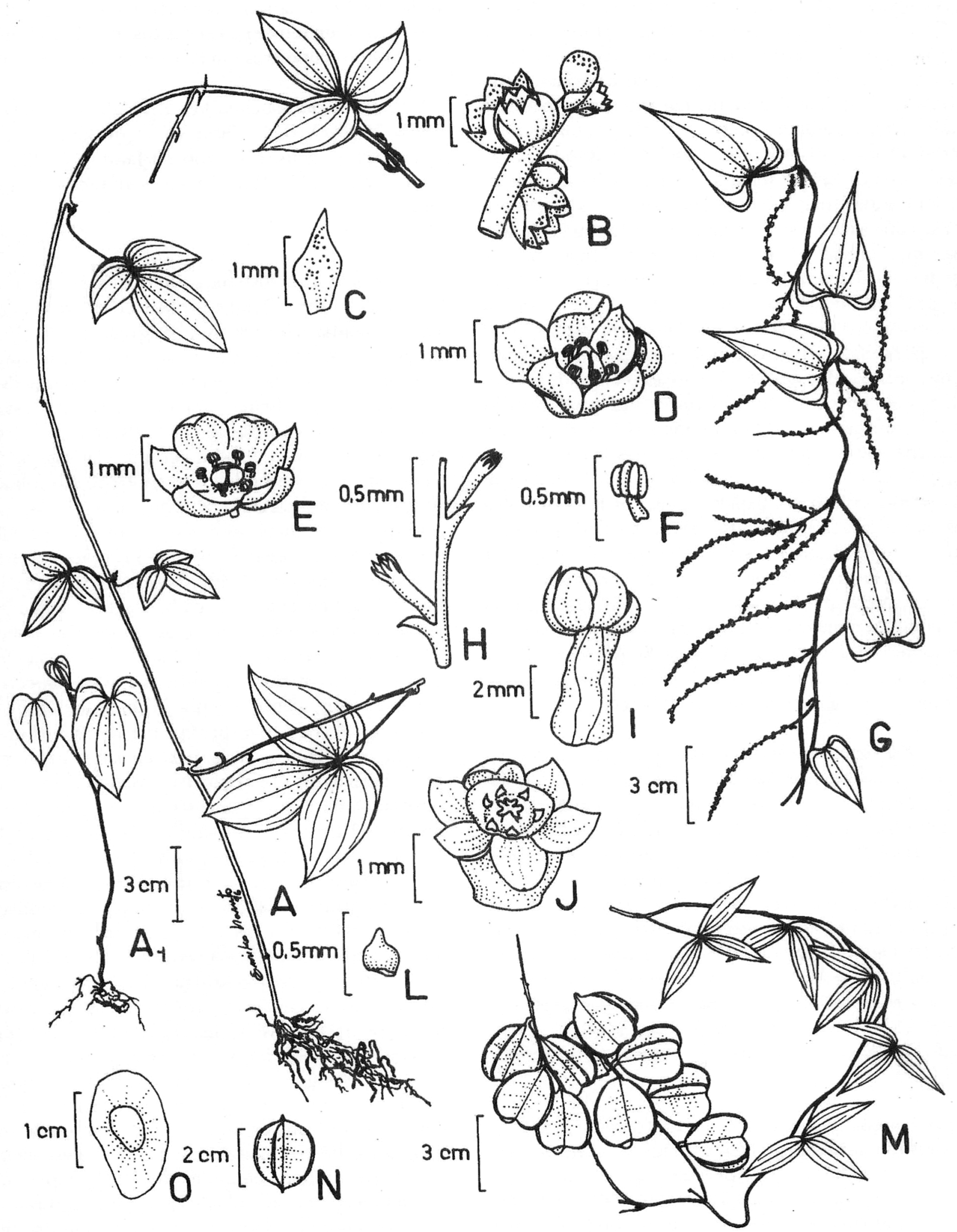

Fig. 25: Dioscorea spicata (Vell.) Pedralli. A. ramo e sistema subterrâneo (rizóforo com tuberosidade lenhosa); A1. plântula; B-F. flor estaminada; B. flores estaminadas em antese e brácteas; C. bráctea; D-E. perigônio, estames e pistilódio; F. estame; G. ramo florífero (planta feminina); H-L. flor pistilada; H. flores jovens e brácteas; I. flor em antese; J. perigônio, estaminódios, estilete e estigma; L. estaminódio; M. ramo em frutificação; N. cápsula; O. semente. (A-F: Pedralli Ẽ Teixeira 3427; G-O: Pedralli Ẽ Teixeira 3441) 
triangular-apiculados, sésseis, castanho-escuros, ca. 0,2 mm compr. Cápsulas 1,5-3cm compr., obovadas a quadrangulares; valvas amareladas a ferrugíneas, cartáceas ou membranáceas, com restos do perigônio no ápice e pequenos pontos avermelhados distribuídos longitudinalmente em relação ao eixo central. Sementes ca. $1 \mathrm{~cm}$ compr., ovaladas, escuras, centrais, com ala circular amarelo-escura, rugosa.

Material examinado: Bahia: Mutuípe, 14.X.1975, L. Mattos Silva 023, fl. masc. (HUEFS); Lençóis, Serra de Chapadinha, 31.VIII.1994, M.L. Guedes et al. 719, fl. fem., fr. (ALCB); Palmeiras, Morro do Pai Inácio, 25.X.1994, A.M. Carvalho et al. 958, fl. masc. (ALCB); Lençóis, Morro da Chapadinha, 27.X.1994, A.M. Carvalho et al. 1113, fr. (ALCB); Lençóis, Morro da Chapadinha, 24.XI.1994, E. Melo et al. 1343, fl. masc. (ALCB); Palmeiras, Morro do Pai Inácio, 30.XII.1994, M.L. Guedes et al. 1511, fr. (ALCB); Lençóis, Serra da Chapadinha, córrego Chapadinha, 6.II.1995, A.M. Giulietti $\mathcal{E} L$. Funch 1596, fr. (ALCB); Morro do Chapéu, Morrão, 8km a oeste da BA-046, 14.III.1995, L.P. Queiroz $\mathcal{E}$ N. Nascimento 4265 , fl. masc. (HUEFS); Palmeiras, Pai Inácio, descida da torre de repetição, 27.VI.1995, M.L. Guedes et al. 1922, fl. fem. (ALCB). Minas Gerais: Diamantina, VI.1934, A.C. Brade 13576, fl. masc. (RB); estrada para Mendanha, $12 \mathrm{~km}$ a nordeste de Diamantina, 28.I.1969, H.S. Irwin et al. 22784, fl. masc. (UB); Diamantina, [estrada para] Inhaí, 28.III.1970, H.S. Irwin et al. 28548 , fl. masc. (UB); Jequitaí, Serra da Macineta, 23.XI.1993, G. Pedralli E Teixeira 3426 (HXBH); a 30km de Jequitaí, 23.XI.1993, G. Pedralli E゚ Teixeira 3427, fl. masc. (HXBH); Santo Hipólito, estrada Corinto-Monjolos, em floresta de galeria do rio Pardo, 24.XI.1993, G. Pedralli Ev Teixeira 3441, fl. fem., fr. (HXBH); Serra da Piedade, Caeté, sem data, Damazio 1486, fl. masc. 1486 (UFOP); Sabará, sem data, Damazio 1489, fl. masc. (UFOP); Serra da Piedade, Caeté, sem data, Damazio 148, fl. masc. (RB); Sabará, sem data, Damazio s. n., fl. masc. (RB); sem local, 1845, Widgren 718 , fl. masc. (K).

Distribuição geográfica e hábitats: D. spicata apresenta distribuição neotropical e exclusiva da América do Sul. $\mathrm{Na}$ Cadeia do Espinhaço a espécie cresce nas áreas abertas dos cerrados, campos rupestres e na borda e interior de florestas de galeria.

Dioscorea spicata distribui-se pelos estados do Mato Grosso, Tocantins, Goiás, Distrito Federal, Minas Gerais e da Bahia até o Paraná, em florestas estacionais (mesófilas), em florestas de galeria em locais sombreados, em solos úmidos, aluvionais e nos cerrados, em solos argilo-arenosos. Nas regiões Sudeste e Sul ocorre na Mata Atlântica das encostas da Serra do Mar e, também, nas restingas. A espécie atinge, ainda, as Guianas e o Peru.
25. Dioscorea stenophylla R. Knuth in Engler \& Prantl, Pflanzenf. 2(5): 84. 1897.

Tipo: Brasil, Goiás, [1894-5], Glaziou 22223, planta masculina (Holótipo B!, Isótipo K!).

Fig. 26

Plantas dióicas. Sistema subterrâneo constituído por um rizóforo curto (ca. $2 \mathrm{~cm}$ compr.), profundo, axial, carnoso, esbranquiçado, do qual se originam pequenas raízes, fasciculadas, esbranquiçadas; periderme e medula alvas. Plantas herbáceas, apoiantes ou, ainda, volúveis, com ramos perenes, delicados, delgados, amarelados a esverdeados, dextrogiros, $10-50 \mathrm{~cm}$ compr., glabros, 0,5-1 mm diâm. Caules jovens em seção transversal circulares, quando mais velhos triangulares, glabros, sem expansões laterais, cobertos por pontuações avermelhado-escuras, com ou sem ornamentação; quando presente, ornamentação papilosa constituída por tricomas irregulares, nas ângulos dos ramos, escuras. Folhas simples, alternas, reduzidas, lineares, cartáceas, 3-5 nervadas, glabras, amareladas a esverdeadas, 4-10 cm compr.; pecíolos longos, filiformes, canaliculados, ca. $4 \mathrm{~mm}$ compr. Inflorescências estaminadas racemosas, terminais, 1,3-3cm compr.; flores 1-3 por nó floral; bráctea oblongo-elíptica, $0,5-0,8 \mathrm{~mm}$ compr., com pontuações avermelhadas esparsas na base; flores com perianto campanulado, albo-amarelado a alaranjado, hialino; tépalas internas e externas oblongo-elípticas, 1-1,4mm compr.; estames 6 , soldados na base, formando uma pequena coluna ao redor do pistilódio, nas flores jovens em início de antese semelhante a um tubo; anteras ca. $0,3 \mathrm{~mm}$ compr., lateral-extrorsas, ovadooblongas, amareladas, deiscência longitudinal, filetes 0,8-1 mm compr., achatados na base, depois cilíndricos; pistilódio cônico-piriforme, íntegro, ca. $0,5 \mathrm{~mm}$ compr., alaranjado-escuro. Inflorescências pistiladas em espigas, pêndulas, $2-8 \mathrm{~cm}$ compr.; flores com perianto campanulado, amarelado a alaranjado-escuro, isoladas em cada nó floral, sésseis; bráctea ovado-acuminada, ca. $0,1 \mathrm{~mm}$ compr. Tépalas internas e externas ovadas a oblongo-acuminadas, $1,5-2 \mathrm{~mm}$ compr.; gineceu tricarpelar, colunar, sulcado longitudinalmente, tripartido no ápice, ramos bífidos, grossos, escuros; estaminódios 6 , hialinos a amarelados, com filetes, inseridos na base do tubo, rudimentos de anteras elípticos, ca. $0,3 \mathrm{~mm}$ compr. Cápsulas 0,5-1 cm compr., oblongas, valvas amareladas, escuras no centro, com as margens dilatadas e restos do perigônio no ápice, rugosas. Sementes ca. 1 mm compr., rugosas, alaranjado-escuras, com asa circular.

Material examinado: Minas Gerais: Santana do Riacho, Serra do Cipó, Chapéu do Sol, XII.1958, A. Duarte 4520, fl. 


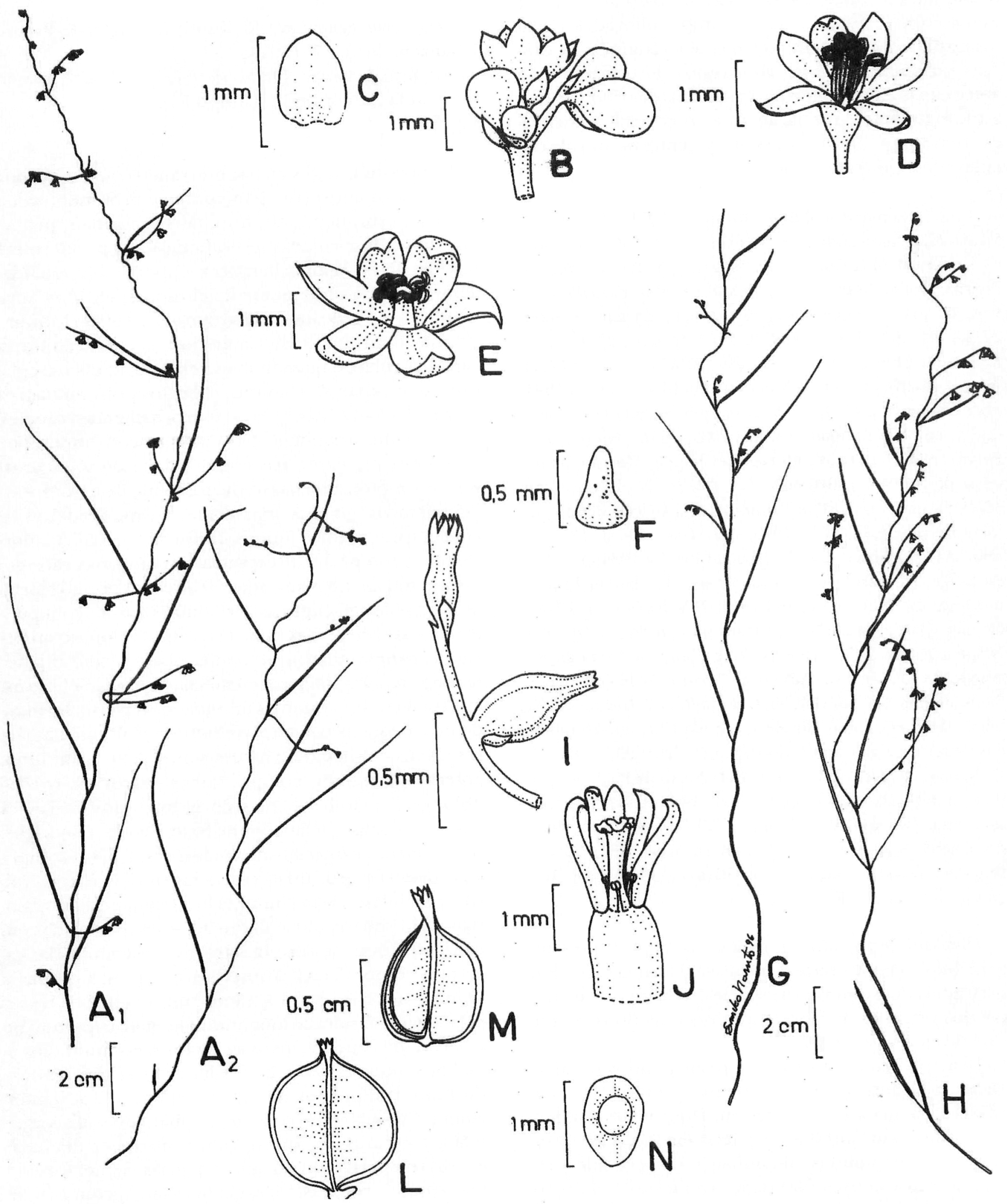

Fig. 26: Dioscorea stenophylla Uline. A1-A2. ramos floríferos (planta masculina); B- F. flor estaminada; B. flores jovens e brácteas; C. bráctea; D. perigônio, estames e pistilódio; E. perigônio e estames soldados; F. pistilódio; G-H. ramos floríferos (planta feminina); I-J. flor pistilada; I. flores jovens e brácteas; J. perigônio, estaminódios, estilete e estigma; L-M. cápsulas; N. semente. (A-F: Arrais et al 6037; G-N: Irwin et al. 20152) 
masc. (HB); Santana do Riacho, Serra do Cipó, 14.II.1968, H.S. Irwin et al. 20012 (UB); Santana do Riacho, Serra do Cipó, estrada Belo Horizonte-Conceição do Mato Dentro, $\mathrm{km}$ 120, 15.II.1968, H.S. Irwin et al. 20152, fl. fem., fr. (UB); Santana do Riacho, Serra do Cipó, estrada da Usina, 9.I.1981, M.C. Henrique et al. 6883, fl. masc. (SPF); Santana do Riacho, Serra do Cipó, km 107 da rodovia Belo HorizonteConceição do Mato Dentro, 13.XI.1984, R.M. Harley et al. 5917, fl. masc. (SPF, K); Santana do Riacho, Serra do Cipó, rodovia Belo Horizonte-Conceição do Mato Dentro, 15.XI. 1984, M.G. Arrais et al. 6037, fl. masc. (SPF, K); Santana do Riacho, Serra do Cipó, rodovia Belo Horizonte-Conceição do Mato Dentro, 15.XI.1984, M.G. Arrais et al. 6037a, fr. (SPF, K); Santana do Riacho, Serra do Cipó, estrada Belo Horizonte-Conceição do Mato Dentro, 13.XI.1984, R.M. Harley et al. 5917, fl. masc. (SPF); km 107, MG-010, km 108, Serra do Cipó, Santana do Riacho, I.1992, F. Vitta s.n., fl. masc. (SPF).

Distribuição geográfica e hábitats: a espécie apresenta distribuição neotropical e exclusiva no Brasil, ocorrendo em áreas abertas nos campos rupestres da Serra do Espinhaço, nas áreas de brejos estacionais, e solos arenosos, encharcados. Até o presente é endêmica da parte mineira do Espinhaço e da serra Geral de Goiás.

26. Dioscorea subhastata Vell., Fl. flum. 10 (ícones): tab. 121. 1831, et in Archos. Mus. Nac. Rio de Janeiro 5: 425. 1881.

Tipo: Vellozo, Fl. flum. 10 (ícones): tab. 121 pr. p., ilustração de planta monóica (excluindo-se os 6 pequenos estames que aparecem em detalhe na prancha) (Lectótipo).

Fig. 27

Plantas monóicas. Sistema subterrâneo constituído por um rizóforo curto (ca. $3 \mathrm{~cm}$ compr.), profundo, com substâncias lipídicas na epiderme e ausência de amido na medula; tuberosidades curtas (ca. $5 \mathrm{~cm}$ compr.), irregulares, lenhosas com a base achatada; periderme amarelada a marrom-escura e medula branco-amarela$\mathrm{da}$ a avermelhada. Tuberosidades originam-se a cada ano do corpo vegetativo principal, semelhantes a pequenos "dedos" de uma mão. Lianas com ramos perenes, esverdeados, amarelados, alaranjados a marromescuros, sem expansões laterais, dextrogiros, eretos, apoiantes a volúveis sobre arbustos e árvores próximas, 1-2,5m compr., glabros, $1-4 \mathrm{~mm}$ diâm. Caules jovens circulares em seção transversal, quando mais velhos transversalmente elípticos, canaliculados, mais robustos na base. Folhas simples, alternas, ovais, deltóides a sagitadas, membranáceas a cartáceas, glabras, esverdeadas, oliváceas, amareladas, alaranjadas a castanho-escuras, com 5-11 nervuras salientes em ambas as faces, 3-15 cm compr.; pecíolos 0,5-5cm compr., canaliculados, glabros, tênues a robustos (nas plantas mais velhas). Inflorescências estaminadas em racemos simples, $5-15 \mathrm{~cm}$ compr., multif loras; bráctea e profilo oval-acuminados, 0,5 $1,2 \mathrm{~mm}$ compr., a primeira sempre mais comprida; flores com perianto campanulado, esverdeado, amarelado a castanho-escuro (após herborização); tépalas internas e externas oblongo-lanceoladas, 1,5-2,2mm compr., coluna estaminal cilíndrica, ápice convexo e base contraída, estames 3 inseridos no ápice da coluna, ou, ainda, estames soldados até a metade da sua altura e anteras no ápice, anteras branco-amareladas, com deiscência longitudinal, oval-oblongas. Inflorescências pistiladas em espigas simples, pêndulas, $5-20 \mathrm{~cm}$ compr., multifloras; bráctea e profilo oblongo-lanceolados, $0,8-1,2 \mathrm{~mm}$ compr.; flores com perianto campanulado, esverdeado, amarelado a alaranjado-escuro, isoladas em cada nó floral, sésseis; tépalas internas e externas oval-lanceoladas, 0,5$1,5 \mathrm{~mm}$ compr.; gineceu tricarpelar, estiletes 3 , divergentes, aplanados, com sulco longitudinal internamente, ramos oblongos, ápice obtuso. Cápsulas $1-2,5 \mathrm{~cm}$ compr., oblongo-elípticas, valvas esverdeadas a alaranjadas (em material seco), apiculadas, com as margens dilatadas. Sementes ca. $10 \mathrm{~mm}$ compr., circulares, alaranjadoescuras, rugosas, com asa circular, mais estreita na base, alongada em direção ao ápice.

Material examinado: Minas Gerais: $12 \mathrm{~km}$ a oeste de Barão de Cocais, Serra do Caraça, 27.I.1971, H.S. Irwin et al. s.n., fl. masc., fl. fem., fr (UB); Santa Bárbara, Prainha, Parque Natural do Caraça, 28.X.1993, G. Pedralli 3417, fr. (НXBH); a $11 \mathrm{~km}$ de Joaquim Felício, vertente leste da Serra do Cabral, 24.XI.1993, G. Pedralli $\mathcal{E}$ Teixeira 3433, fl. masc., fl. fem., fr (HXBH); Belo Horizonte, bairro Taquaril, mata da sede do Country Club, 29.IV.1992, G. Pedralli 3373, fr. ( $\mathrm{HXBH})$.

Distribuição geográfica e hábitats: com distribuição neotropical e exclusiva da América do Sul, D. subhastata na Serra do Espinhaço é encontrada no interior de florestas de galeria, em locais úmidos, bem sombreados e em fendas das rochas, onde exista pelo menos uma camada inicial de solo, em meio a galhos e folhas em decomposição.

Dioscorea subhastata ocorre no interior de florestas pluviais (Mata Atlântica do sudeste do Brasil), florestas temperadas (Floresta de Araucária do sul do Brasil), florestas de galeria, na borda de florestas estacionais (mesófilas) e em fendas dos afloramentos rochosos dos campos rupestres. Distribui-se pelos estados de Pernambuco, Mato Grosso, Minas Gerais e do Rio de Janeiro até o Rio Grande do Sul. Ocorre, ainda, no Paraguai, na Bolívia e no Peru, em altitudes entre 2.800 e 3.000 m.s.n.m. 


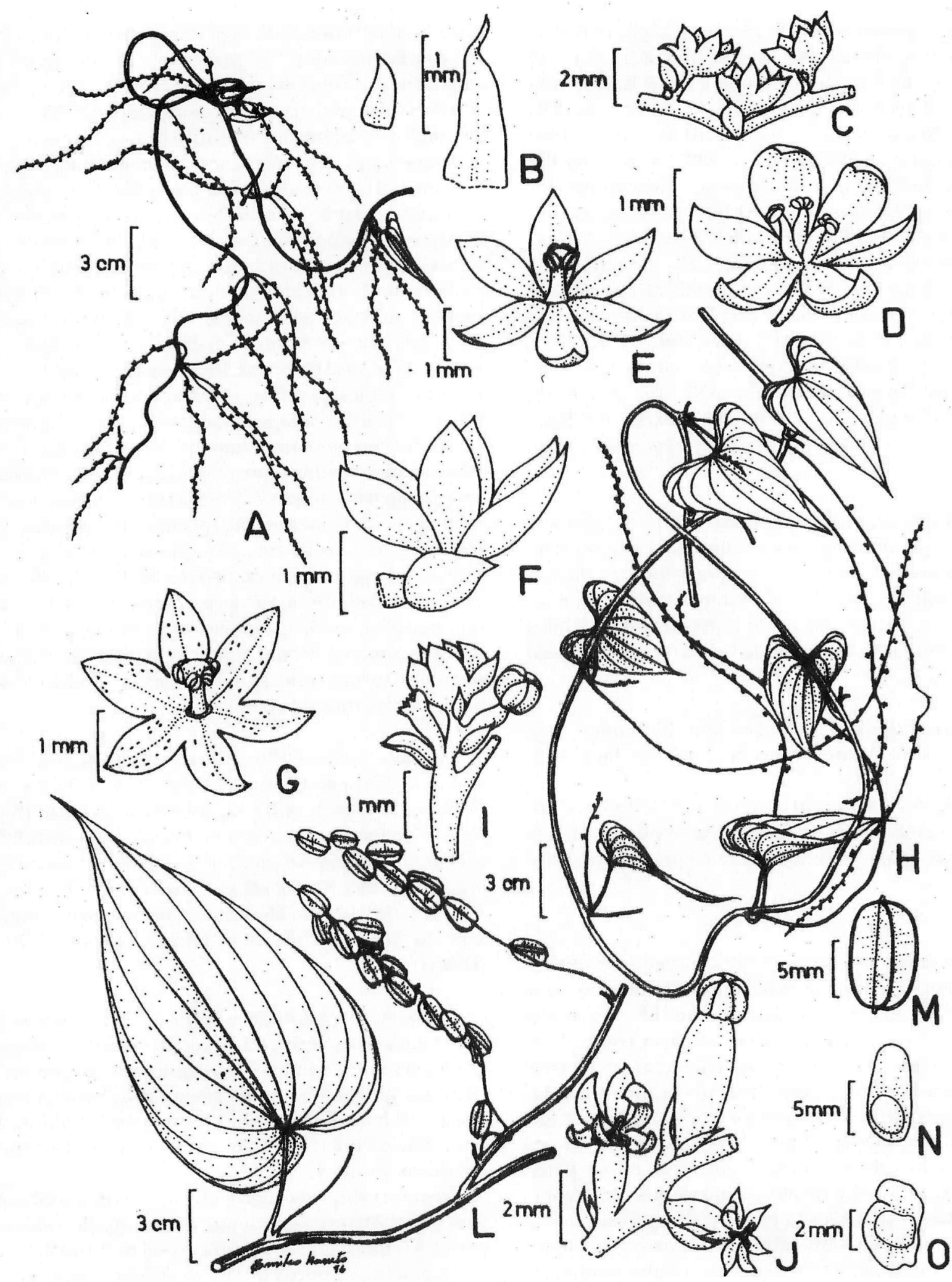

Fig. 27: Dioscorea subhastata Vell. A. ramo florífero com flores estaminadas; B-F. flor estaminada; B. bráctea (apiculada) e profilo; C. flores em antese, brácteas e profilos; D. perigônio, coluna estaminal e anteras; E. flor em antese e bráctea; F. perigônio, coluna estaminal e anteras; G. ramo florífero com flores pistiladas; H-I. flor pistilada; H. flores em antese e brácteas; I. flores em antese, brácteas e profilos; J. ramo em frutificação; L. cápsula; M-N. sementes. (A-N: Pedralli Ẽ Teixeira 3433) 
27. Dioscorea trifida L. f, Suppl. pl., ed. 6, p. 427. 1781. Tipo: Suriname, Allamand s.n. (Holótipo LINN!). Fig. 28

Plantas dióicas. Sistema subterrâneo constituído por um rizóforo alongado (ca. 0,5m compr.), profundo, com tuberosidades distribuídas ao longo do seu eixo; medula avermelhada e periderme marrom-escura, verrucosa. Do rizóforo se originam a cada ano várias tuberosidades menores, laterais, ovais, cilíndricas, arredondadas ou irregulares, semelhantes à 'batatas' ou 'moelas'; periderme acinzentada a marrom-escura, com medula amarelo-alaranjada ou purpúrea. Liana com ramos perenes, com expansões laterais, esverdeados, amarelados, castanhos ou cinza-escuros, sinistrogiros, eretos ou apoiantes sobre árvores e arbustos, 1-5m compr., pilosos, 2-5mm diâm. Caules jovens e velhos em seção transversal pentagonais, angulosos, "alados", papilosos e com densa pilosidade nas reentrâncias (canalículos). Folhas alternas ou opostas nos ramos jovens, palmatilobadas, 3-5 lobos acuminados ou ovais-agudos a obtusos, membranáceas a cartáceas, escabrosas em ambas as faces, 4$13 \mathrm{~cm}$ compr.; pecíolos robustos, retorcidos na sua inserção, comprimidos, depois "alados", canaliculados, com densa pilosidade nas reentrâncias, $1-15 \mathrm{~cm}$ compr. Inflorescências estaminadas em racemos, $5-18 \mathrm{~cm}$ compr., 1-5 flores por nó, curtamente pediceladas; bráctea oblongo-acuminada, ca. 2,5mm compr.; profilo com a mesma forma, ca. $1,9 \mathrm{~mm}$ compr.; flores com perianto rotado, esverdeadas, amareladas a castanho-escuras, pilosas; tépalas internas e externas oblongo-acuminadas, 2,5-3mm compr.; estames 6, longos, curvos no terço superior, inseridos na base de cada tépala; anteras ca. $0,4 \mathrm{~mm}$ compr., introrsas, oblongas e largamente ovais, deiscência longitudinal, filetes $1,3-1,5 \mathrm{~mm}$ compr., cilíndricos; pistilódio colunar, alargado no ápice, trilobado, ca. $1 \mathrm{~mm}$ compr., estilódios curtos, grossos, ca. $0,5 \mathrm{~mm}$ compr. Inflorescências pistiladas em espigas, pêndulas, ca. $10 \mathrm{~cm}$ compr.; flores com perianto campanulado, tubo longo, amareladas a alaranjado-escuras, isoladas em cada nó floral, sésseis, com bráctea na base, elíptico a oblongo-lanceolada, ca. 1,5mm compr. Tépalas internas e externas oblongo-lanceoladas, 1,5$2 \mathrm{~mm}$ compr., gineceu tricarpelar, colunar, grosso, alargado na base, ramos divergentes no ápice, bífidos; estaminódios 6, branco-amarelados, pedicelos longos, ca. $0,8 \mathrm{~mm}$ compr., curvos no ápice; rudimentos de anteras oblongos. Cápsulas $2-2,7 \mathrm{~cm}$ compr., elíptico-oblongas, valvas glabras a pubérulas, amareladas a alaranjado-escuras em material seco, apiculadas, margens levemente dilatadas. Sementes ca. $5 \mathrm{~mm}$ compr., circulares, castanho-escuras, lisas, com pontuações escuras esparsas; ala circular, irregular nas margens, hialina.
Material examinado: Minas Gerais, Diamantina, $\mathrm{km} 20$ da estrada para Inhaí, 25.VII.1986, G. Pedralli $\mathcal{E}$ G. Silva 2661, fl. masc. (CEN).

Distribuição geográfica e hábitats: Dioscorea trifida tem distribuição neotropical, nas Américas Central e do Sul. A espécie ocorre nas florestas pluviais tropicais das Américas do Sul e Central, nos cerrados do planalto Central do Brasil, nos campos rupestres da Serra do Espinhaço e em florestas estacionais (mesófilas) adjacentes a esses campos. Ocorre desde as ilhas do Caribe (Jamaica, Porto Rico, Trinidad e Tobago, Antilhas) até a América do Sul, incluindo Guianas, Equador, Colômbia, Peru e Brasil (Amazonas, Pará, Maranhão, Piauí, Paraíba, Mato Grosso, Goiás, Bahia e Minas Gerais).

\section{Conclusões}

Através do levantamento florístico das Dioscoreaceae da Cadeia do Espinhaço nos estados de Minas Gerais e Bahia, da consulta a herbários nacionais e estrangeiros, representando 192 táxons, foi possível reconhecer e delimitar morfologicamente 27 espécies de Dioscorea, único gênero ocorrente nesta região.

O estudo comparado dos caracteres florais e vegetativos, em especial dos sistemas subterrâneos e dos caules aéreos das Dioscorea da Serra do Espinhaço indicou que esses últimos caracteres, nunca utilizados em trabalhos anteriores, mostram-se importantes na diferenciação das espécies.

As espécies estudadas foram incluídas em três padrões principais de distribuição geográfica: pantropical (3 espécies), americano-africana ( 1 espécie) e neotropical (23 espécies). Neste último padrão estão incluídos dois subpadrões: América Central e América do Sul (3 espécies); só na América do Sul, com dois subpadrões: Brasil e outros países (12 espécies) e exclusivo do Brasil (8 espécies). O outro padrão geral foi de distribuição restrita à Cadeia do Espinhaço e Serra Geral de Goiás apresentado apenas por D. anomala, D. maianthemoides e $D$. stenophylla. Este padrão tinha sido citado como um dos mais importantes para espécies de plantas da Cadeia do Espinhaço por Giulietti \& Pira- ni (1988) e por Cavalcanti (1995) para Diplusodon (Lythraceae).

\section{Agradecimentos}

A realização deste trabalho deveu-se, em parte, à imprescindível ajuda das seguintes pessoas, às quais o autor agradece: Dr. ${ }^{a}$ Ana Maria Giulietti (orientadora/ USP), Biól. Maria do Carmo Brandão Teixeira (SAT/ CETEC), Drs. Antonio Salatino, Nelson Papavero, Renato de Mello Silva, José Rubens Pirani (Dep. ${ }^{10}$ Botâni- 


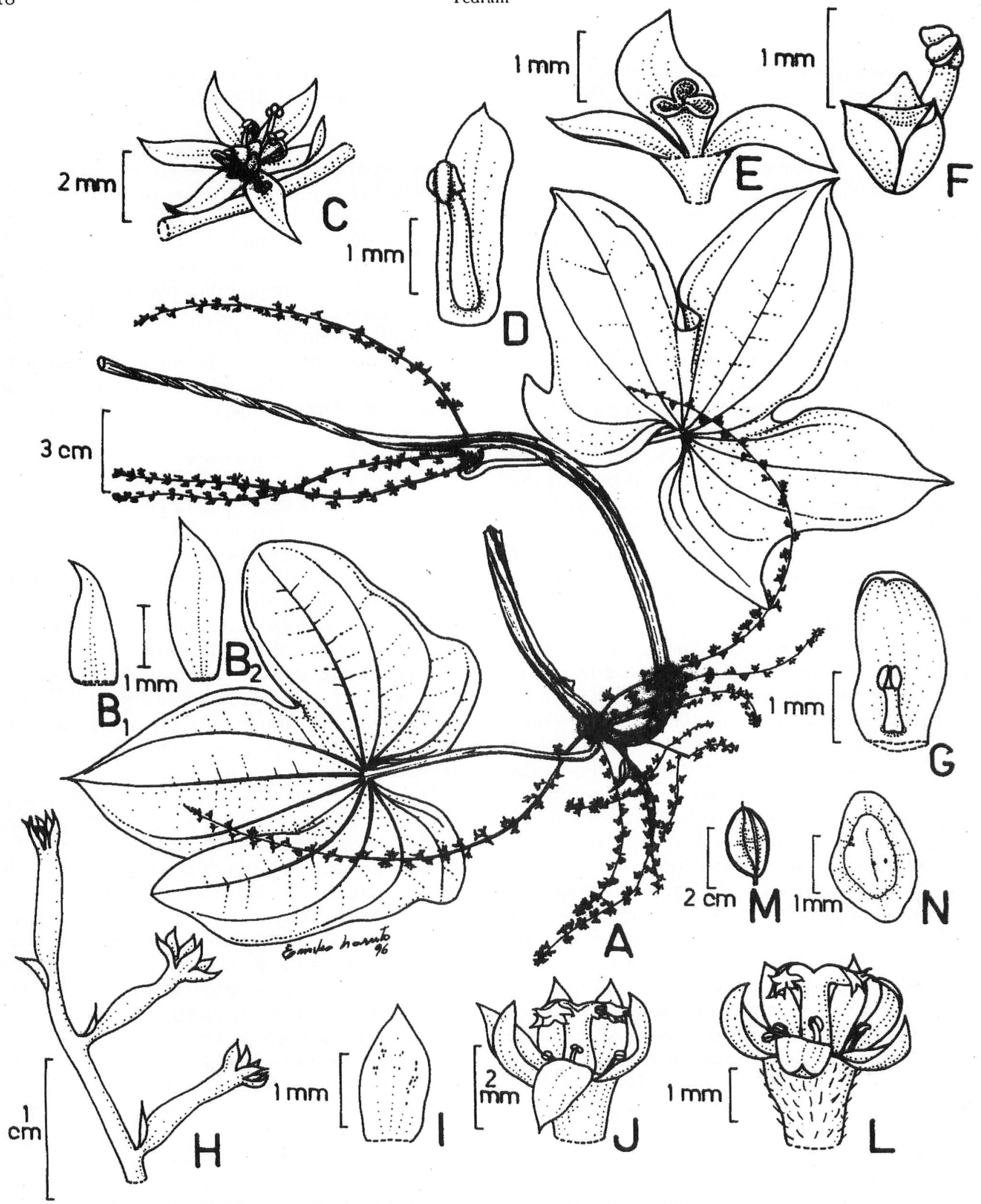

Fig. 28: Dioscorea trifida L.f. A. ramo florifero (planta masculina); B1-G. flor estaminada; B1. profilo; B2. bráctea; C. perigônio, estames e pistilódio; D. tépala e estame; E. tépalas e pistilódio colunar; F. pistilódio e estame; G. tépala e estame jovem; H-L. flores pistiladas; H. flores pistiladas em antese e brácteas; I. bráctea; J-L. perigônios, estaminódios, estiletes e estigmas; M. cápsula; N. semente. (A-G: Pedralli $\mathcal{E}$ Silva 2661; H-N: W. Balée 2629) 


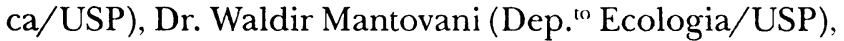
Pesquisadores Paul Wilkin, Daniela Zappi, Brian L. Stannard, Jill Cowley, Nigel Taylor (RBG, Kew, U.K.), Dr. Green Lucas (curador do Herbário K. U.K.), Roy Vickey (curador do Herbário BM, Londres, U.K.), Miss Gina Douglas (Herbário LINN, Londres, U.K.), Prof. ' Serena Manner (Herbário OXF, Oxford, U.K.), Dr. Charlie Jarvis (Museu Britânico e Sociedade Lineana de Londres, U.K.), Drs. Paul Hiepko, Madjit Hakki e Thomas Raus (Jardim Botânico e Herbário B, Berlin, Alemanha), Drs. Wolfgang Lippert e Franz Schuhwerk (Herbário M, Munique, Alemanha), Dr. Philip Morat (Herbário P, Paris, França), curadores dos herbários brasileiros, Dr." Aristéa Alves Azevedo e Biól. Gilmar Valente (Dep." Botânica/UFV, Viçosa, MG), Dr."is Maria Leonor del Rey Souza (UFSC, Florianópolis, SC), Arlete Aparecida Soares (UFC, Fortaleza, CE), Maria Helena Resende (UFG, Goiânia, GO), Eng. Fábio Domingues (Fortaleza, CE).

\section{Referências}

AL-SHEHBAZ, I.A. \& SCHUBERT, B.G. 1989. The Dioscoreaceae in the Southeastern United States. J. Arnold Arb. 70: 57-95.

AYENSU, E.S. 1972. Conments on old and new Dioscoreas of commercial importance. Publ. Esp. Inst. Nac. Invest. Forest. 8: 75-81.

BAILEY, L.H. 1951. Manual of cultivated plants. Macmillan Publ. Co. New York.

BARROSO, G.M., SUCRE, D., GUIMARĀES, E.F., CARVALHO, L.F., VALENTE, M.C., SILVA, J.D., SILVA, J.B., ROSENTHAL, F.R.T., BARTH, O.M. \& BARBOSA, A.F. 1974. Flora da Guanabara: família Dioscoreaceae. Sellowia (25): 9-256.

BRUMMITT, R.K. 1992. Vascular plant families and genera. Royal Botanic Gardens. Kew.

BURKILL, I.H. 1951. Dioscoreaceae. Flora Malesiana 4(1): 293-335.
CAVAlCANTI, T.B. 1995. Revisão de Diplusodon Pohl (Lythraceae). Tese de doutorado. Instituto de Biociências, Universidade de São Paulo. São Paulo.

COURSEY, D.G. 1979. Evolution of crop plants. Longman. London. COURSEY, D.G. 1980. Descriplors of yam (Dioscorea sp.). IBPGR Secretariat. Rome.

CRONQUIST, A. 1988. The evolution and classification of flowering plants. The New York Botanical Garden. New York.

GIULIETTI, A.M. \& PIRANI, J.R. 1988. Patterns of geographic distribution of some species from the Espinhaço range, Minas Gerais and Bahia, Brazil. In P.E. Vanzolini \& W.R. Heyer (eds.). Proceedings of a workshop on Neotropical distribution palterns. Academia Brasileira de Ciências e Letras. Rio de Janciro, p. 39-69.

HOLMGREN, P.K., HOLMGREN, N.H. \& BARNETT, L.C. 1990. Index Herbariorum, Part I: The Herbaria of the World. I.A.P.T./ New York Botanical Garden. New York.

KNUTH, R. 1924. Dioscoreaceae. In A. Engler (ed.) Das Pflanzenreich 4(43). Wilhelm Engelmann. Leiprig, p. 1-386.

LAWRENCE, G.H.M. 1975. Taxonomia das Plantas Vasculares. Fundação Calouste Gulbenkian. Lisboa.

PEDRALLI, G. 1998. Revisão taxonômica das espécies de Dioscoreaceae (R.Br.) Lindley da Cadeia do Espinhaço, Minas Gerais e Bahia, Brasil. Tese de Doutorado. Instituto de Biociências, Universidade de São Paulo. São Paulo.

PURSEGLOVE, J.W. 1979. Tropical crops: monocotyledons. Longman. Singapore.

ROCHA, D.C. \& MENEZES, N.L. 1997. O sistema subtcrrâneo de Dioscorea kunthiana Uline ex R. Knuth (Dioscoreaceae). Bol. Bot. Univ. São Paulo 16: 1-13.

SMITH, B.W. 1937. Notes on the cytology and distribution of the Dioscoreaceae. Bull. Torrey Bot. Club (64): 189-197.

THORNE, R.F. 1972. Major disjunctions in the geographic ranges of seed plants. Quart. Rev. Biol. 47(4): 366-367.

WAITT, A.W. 1963. Yams, Dioscorea species. Field Crop Abstr. 16(3): 145-157.

XIFREDA, C.C. 2000. Evaluation of pollen and vegetative characters in the systematics of South American species of Dioscorea (Dioscoreaceae).In K.L. Wilson \& D.A. Morrison (eds) Monocots: systematics and evolution. CSIRO. Melbourne, p.488-496. 